\section{Potential Use of Dry Cooling in Support of Advanced Energy Generation Systems}

D.W. Mayer

E. M. Arnold

R. T. Allemann

September 1979

Prepared for the U.S. Department of Energy under Contract EY-76-C-06-1830

Pacific Northwest Laboratory Operated for the U.S. Department of Energy by Battelle Memorial Institute 


\title{
NOTICE
}

This report was prepared as an account of work sponsored by the United States Government. Neither the United States nor the Department of Energy, nor any of their employees, nor any of their contractors, subcontractors, or their employees, makes any warranty, express or implied, or assumes any legal liability or responsibility for the accuracy, completeness or usefulness of any information, apparatus, product or process disclosed, or represents that its use would not infringe privately owned rights.

The views, opinions and conclusions contained in this report are those of the contractor and do not necessarily represent those of the United States Government or the United States Department of Energy.

\author{
PACIFIC NORTHWEST LABORATORY \\ operated by \\ BATTELLE \\ for the \\ UNITED STATES DEPARTMENT OF ENERGY \\ Under Contract EY-76-C-06-1830
}

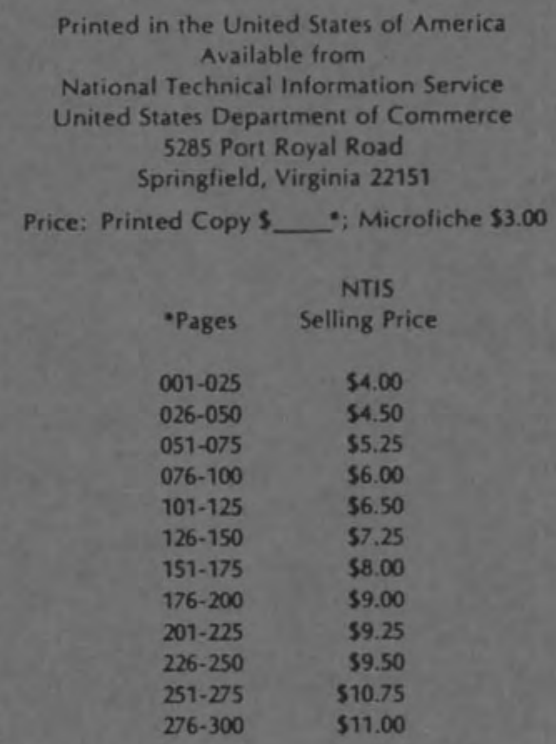


PNL -3149

33679000536401

UC -12

POTENTIAL USE OF DRY COOLING IN SUPPORT OF ADVANCED ENERGY GENERATION SYSTEMS

D. W. Mayer

E. M. Arnold

R. T. Allemann

September 1979

Prepared for

the U.S. Department of Energy under Contract EY-76-C-06-1830

Pacific Northwest Laboratory

Richland, Washington 99352 


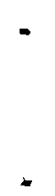

.

. 


\title{
FOREWORD
}

The Dry Cooling Enhancement Program at Pacific Northwest Laboratory (PNL) was initiated with a program scope that included the following near-term and ultimate emphases.

Near-Term Objectives:

- Develop economic and performance models for cost optimization of total heat rejection systems using dry and dry/wet cooling.

- Analyze and disseminate operating experience on existing dry-cooled plant performance.

- Demonstrate certain features of existing technology equipment to provide confidence for specification by utilities.

Ultimate Objective:

- Promote water conservation through industry use of dry cooling by developing and demonstrating the reliability of lower cost systems. The development of advanced dry/wet systems is also considered to be within this scope.

The following documents have been issued, reporting the results of the work toward these objectives.

Cost optimization of dry-cooled heat rejection systems:

\author{
A REVIEW AND ASSESSMENT OF ENGINEERING ECONOMIC STUDIES OF \\ DRY-COOLED ELECTRICAL GENERATING PLANTS. B. C. Fryer, \\ BNWL-1976, March 1976. \\ HEAT TRANSFER AND PRESSURE DROP CHARACTERISTICS OF DRY \\ TOWER EXTENDED SURFACES. PART I: HEAT TRANSFER AND PRES- \\ SURE DROP DATA. PFR Engineering Systems, Inc., PFR 7-100, \\ March 1976. \\ HEAT TRANSFER AND PRESSURE DROP CHARACTERISTICS OF DRY \\ TOWER EXTENDED SURFACES. PART II: DATA ANALYSIS AND \\ CORRELATION. PTR Engineering Systems, Inc., PFR 7-102, \\ June 1976.
}


Analysis of performance of existing dry-cooled plants:

DRY COOLING TOWER PROGRAM: RESULTS OF INDUSTRIAL CONTACTS THROUGH AUGUST 1974. BNWL-1878, November 1, 1974.

A SURVEY OF MATERIALS AND CORROSION PERFORMANCE IN DRY COOLING APPLICATIONS. A. B. Johnson, Jr., D. R. Pratt and G. E. Zima, BNWL-1958, March 1976.

EUROPEAN DRY COOLING TOWER OPERATING EXPERIENCE.

J. G. DeSteese and K. Simhan, BNWL-1955, March 1976.

MATHEMATICAL AND EXPERIMENTAL INVESTIGATIONS ON DISPERSION AND RECIRCULATION OF PLUMES FROM DRY COOLING TOWERS AT WYODAK POWER PLANT IN WYOMING. Y. Onishi and D. S. Trent, BNWL-1982, February 1976.

ALUMINUM ALLOY PERFORMANCE UNDER DRY COOLING TOWER CONDITIONS. A. B. Johnson, Jr., S. Begaj, M. W. Martini, and R. P. May, PNL-2392, December 1977.

Advanced dry (dry/wet)-cooled systems:

PRELIMINARY EVALUATION OF WET-DRY COOLING CONCEPTS FOR

POWER PLANTS. W. B. Loscutoff, BNWL-1969.

COMPATIBILITY OF AMMONIA WITH CANDIDATE DRY COOLING SYSTEM MATERIALS. D. R. Pratt, BNWL-1991, Apri1 1976.

SCALE FORMATION IN DELUGED DRY COOLING SYSTEMS.

D. R. Pratt, BNWL-2060, March 1976.

AMMONIA AS AN INTERMEDIATE HEAT EXCHANGE FLUID DRY FOR DRYCOOLED TOWERS. R. T. Allemann, B. M. Johnson, and

G. C. Smith, BNWL-SA-5997, September 1976.

AUGMENTED DRY COOLING SURFACE TEST PROGRAM: ANALYSIS AND

EXPERIMENTAL RESULTS. H. L. Parry et al. PNL-2746, September 1979 .

A group of reports (including this report) has been issued that serves the dual purpose of: 1) developing cost optimization models for dry cooling systems based on available technology and 2) comparing the results of analyzing the costs of these systems with the projected cost of several advanced dry and $d r y /$ wet systems. Included in this group are: 
AN ENGINEERING AND COST COMPARISON OF THREE DIFFERENT ALL-DRY COOLING SYSTEMS. B. C. Fryer, D. W. Faletti, Daniel J. Braun, David J. Braun and L. E. Wiles, BNWL-2121, September 1976.

A STUDY OF THE COMPARATIVE COSTS OF FIVE WET/DRY COOLING TOWER CONCEPTS. F. R. ZaToudek, R. T. ATlemann, D. W. Faletti, B. M. Johnson, H. L. Parry, G. C. Smith, R. D. Tokarz, and R. A. Walter, BNWL-2122, September 1976.

DRY COOLING OF POWER GENERATING STATIONS: A SUMMARY OF THE ECONOMIC EVALUATION OF SEVERAL ADVANCED CONCEPTS VIA A DESIGN OPTIMIZATION STUDY AND A CONCEPTUAL DESIGN AND COST ESTIMATE. B. M. Johnson, R. T. Allemann, D. W. Faletti, B. C. Dryer and F. R. Zaloudek, BNWL-2120, September 1976.

COSTS AND COST ALGORITHMS FOR DRY COOLING TOWER SYSTEMS. P. A. Ard, C. H. Henager, D. R. Pratt and L. E. Wiles, BNWL-2123, September 1976.

A USER'S MANUAL FOR THE BNW-I OPTIMIZATION CODE FOR DRY-COOLED POWER PLANTS. David J. Braun, Daniel J. Braun, Warren V. DeMier, D. W. Falett $i$ and L. E. Wiles, BNWL-2180, January 1977.

COMPARATIVE COST STUDY OF FOUR WET/DRY COOLING CONCEPTS THAT USE AMMONIA AS THE INTERMEDIATE HEAT EXCHANGE FLUID. R. D. Tokarz, Daniel J. Braun, B. M. Johnson, R. T. Allemann, David J. Braun, H. L. Parry, G. C. Smith and F. R. Zaloudek, PNL-2661, September 1978.

AN ENGINEERING AND COST ANALYSIS OF A DRY COOLING SYSTEM AUGMENTED WITH A THERMAL STORAGE POND. M. K. Dorst and R. T. A17emann, PNL-2745, September 1978.

A USER'S MANUAL FOR THE BNW-II OPTIMIZATION CODE FOR DRY/WET-COOLED POWER PLANTS. Danie 1 J. Braun, Judith A. Bamberger, David J. Braun, Duane W. Faletti, Lawrence E. Wiles, PNL-2674, Vol. I, May 1978.

A DESCRIPTION AND COST ANALYSIS OF A DELUGE DRY/WET COOLING SYSTEM. L. E. Wiles et al. PNL-2498, June 1978.

Four reports have been issued which consider the future need for any cooling and the potential benefit/cost ratio of a large-scale demonstration. 
AN OVERVIEW OF ECONOMIC, LEGAL, AND WATER AVAILABILITY FACTORS AFFECTING THE DEMAND FOR DRY AND WET/DRY COOLING OF THERMAL POWER PLANTS. P. L. Hendrickson, BNWL-2268, June 1977.

AN OVERVIEW OF ECONOMIC, LEGAL, AND WATER AVAILABILITY FACTORS AFFECTING THE DEMAND FOR DRY AND WET/DRY COOLING OF THERMAL POWER PLANTS. P. L. Hendr ickson, BNWL-2268, September 1978.

ESTIMATION OF BENEFITS FROM DEMONSTRATING ADVANCED DRY COOLING TECHNOLOGY: A FRAMEWORK AND PARTIAL ANALYSIS. J. W. Currie and T. J. Foley, BNWL-2182, Apri1 1977.

POTENTIAL USE OF DRY COOLING IN SUPPORT OF ADVANCED ENERGY GENERATION SYSTEMS. D. W. Mayer, E. M. Arnold, and R. T. ATlemann, PNL-3149, September 1979. 


\section{SUMMARY}

Advanced energy technologies are being developed to produce alternative methods for meeting the increasing demand for energy in the United States. Some of the potential alternatives are:

- solar

- geotherma 1

- coal gasification

- coal liquefaction

- clean solid fuel from coal

- oil shale.

Studies on advanced energy technologies indicate that these processes will generate a significant percentage of waste heat which must be dissipated by cooling devices. Methods for cooling include:

- once-through cooling

- cooling lakes or ponds

- wet cooling towers

- dry and wet/dry cooling towers.

The six energy technologies listed above are likely to be developed in the Southwestern or Western states where water availability problems are already apparent or are projected to become significant in the relatively near future. Therefore, dry cooling will probably be considered.

Since plant performance penalties are associated with the use of dry cooling, other factors must be present to influence a decision to use dry cooling. The overriding incentive will be the inability to obtain adequate water for other types of cooling. Water may not be available due to prior allocation for other uses, and transfer of water rights to energy development may not be allowed. Environmental concerns over discharge of heat to water bodies, associated impacts on biota in the water body, as well as increases in water salinity due to the consumptive use of water may also have an influence on the decision to use dry cooling. 
Solar electric plants will be located where there is a high level of incident solar energy. Not surprisingly these regions usually have very little precipitation and, consequently, water may be at a premium. Accordingly, the incentive for using dry cooling with a solar power plant is quite high. A secondary benefit would be the absence of drift that is associated with wet towers. Tower drift could be deposited on and subsequently degrade the mirrors that are used to focus the sunlight. Also, the plume from a wet tower could block the incident sunlight and reduce the plant output.

Geothermal plants, because of their low efficiencies, are quite sensitive to the waste heat sink temperature; however, they generate much higher amounts of waste heat for a given power output than conventional power plants. If wet towers are used, the consumptive use of water will be much greater per unit of power output than for a conventional plant. At present, most plants can supply the required make-up water from the steam condensate. If ground subsidence becomes a problem balanced withdrawal and reinjection may be required. This will require an outside water source and therefore enhance the possibility of dry cooling. The use of binary cycle plants will also require an outside water source. Since many of the more promising geothermal areas are in water constrained regions, dry cooling may be necessary. At least one study has indicated that if a binary cycle geothermal plant is operated in a floating power mode with dry cooling it could be economically competitive with a conventionally operated binary cycle geothermal plant using wet cooling.

The primary factor indicating the potential need for dry cooling for synthetic fuel production is the lack of sufficient water in most of the regions where the coal and oil shale are found. It appears that lack of water may be a limiting factor on the level of synthetic fuel production; consequently, the use of dry cooling could be desirable. 


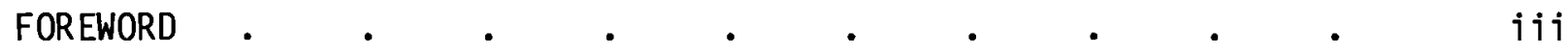

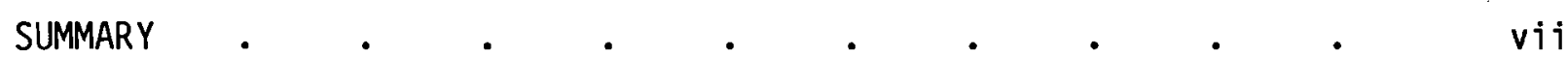

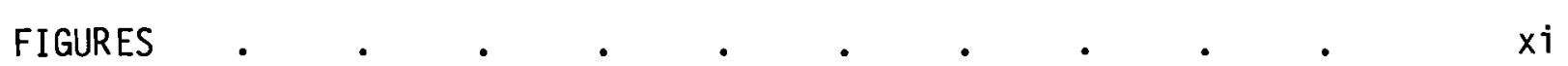

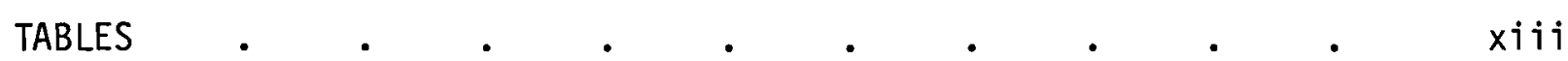

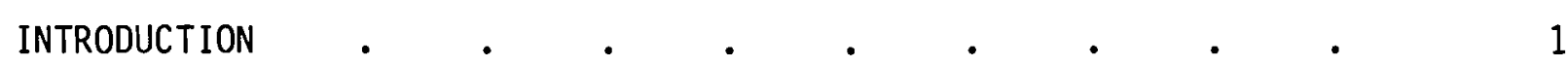

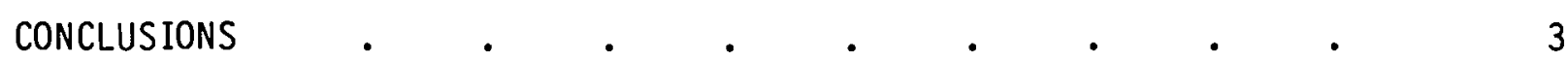

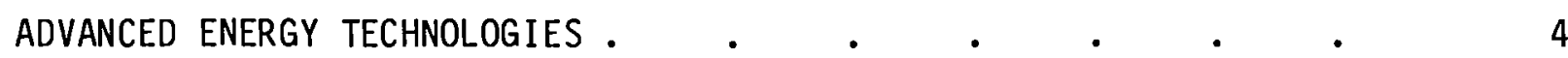

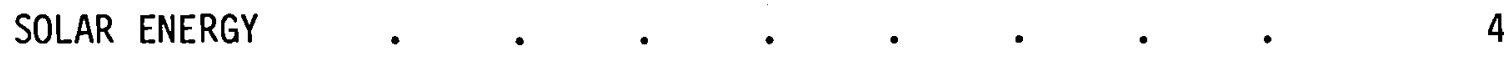

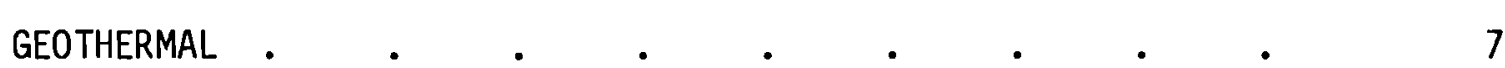

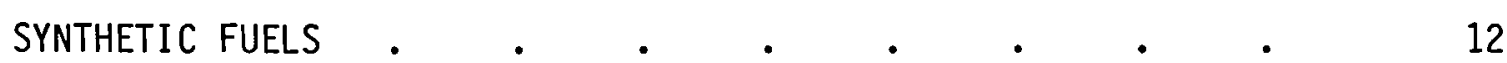

CHARACTERISTICS OF COOLING OPTIONS

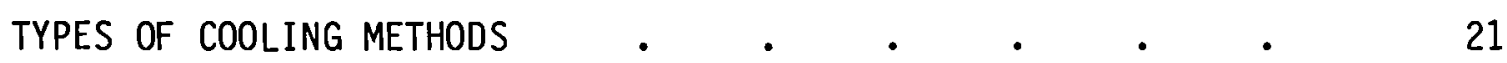

WATER CONSUMPTION

ENERGY AND RELATED WASTE HEAT GENERATION • . . . . . $\quad 30$

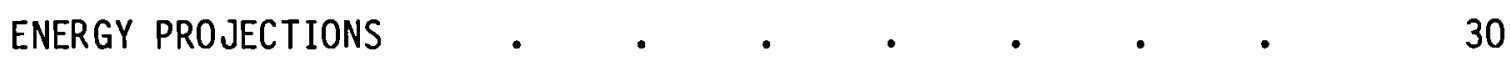

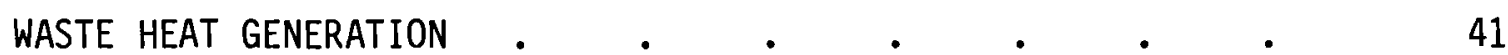

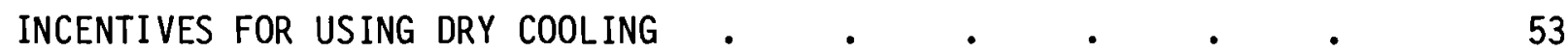

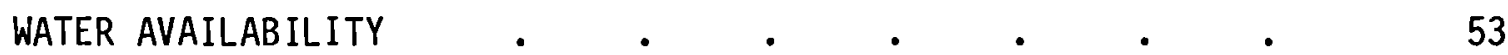

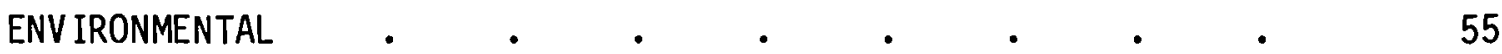

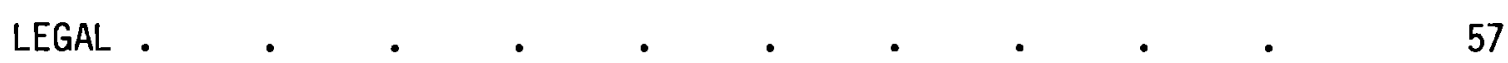

ALTERNATIVE ENERGY TECHNOLOGIES AND DRY COOLING REQUIREMENTS 61

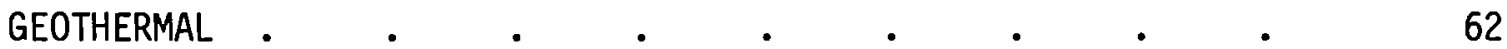

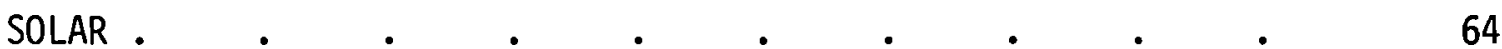

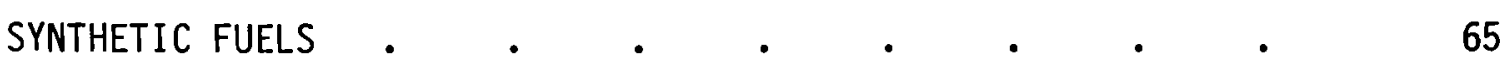




\section{CONTENTS (contd)}

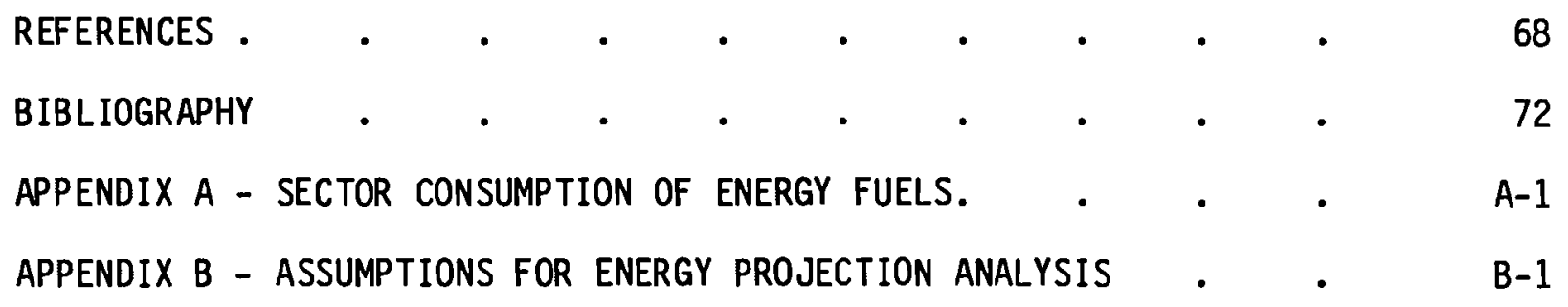




\section{FIGURES}

1 Simplified Schematic of a Solar Central Tower

2 Simplified Schematic of a Typical Geothermal Power

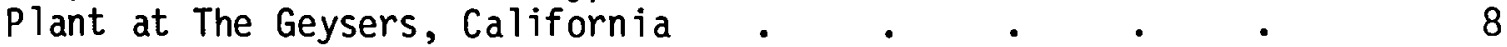

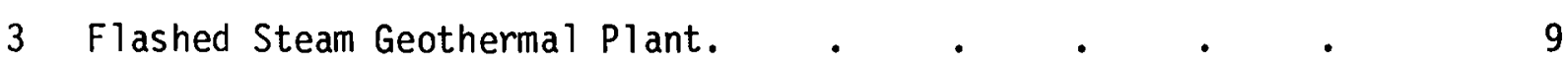

4 Simplified Schematic of a Multistage Evaporation

Binary Cycle Geothermal Power Plant . . . . . . 11

5 Possible Methods of Producing Synthetic Fuels . . . . $\quad 13$

6 Simplified Flow Diagram for a High Btu Coal Gasification

Plant Based on the Synthane Process. . . . . . 14

7 Simplified Flow Diagram for a High Btu Coal Gasification

Plant Based on the Hygas Process $. \quad . \quad . \quad . \quad . \quad 15$

8 Water Streams in a Synthetic 0il Plant $\quad . \quad . \quad . \quad . \quad 16$

9 Flow Diagram for a Possible Method of Producing Hydrogen During the Production of Synthetic $0 i 1$.

10 Water Streams in a Solvent Refined Solid Fuel Plant . . $\quad 18$

11 Flow Diagram for an $0 i l$ Shale Plant . $\quad . \quad \ldots \quad$. $\quad . \quad 18$

12 Schematic of an $0 i 1$ Shale Upgrading Plant . . . . . . 19

13 Schematic of a Once-Through Cooling System $\quad$ - $\quad$ e $\quad$ e 22

14 Schematic of an Evaporative Cooling System $\quad$ - $\quad$ e $\quad 24$

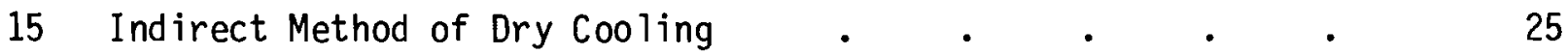

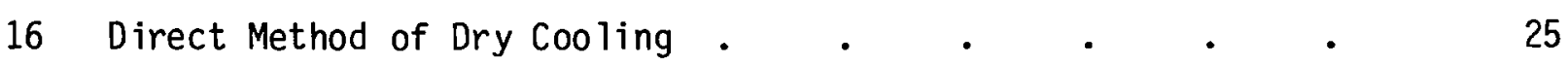

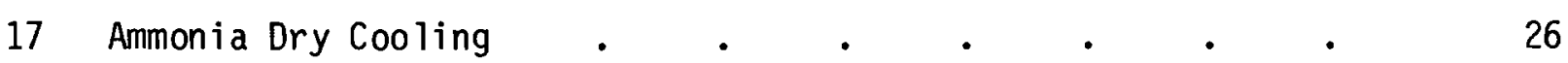

18 Combination Wet/Dry Cooling System Using Separate Cooling Modules . $\quad . \quad$. $\quad . \quad \ldots \quad . \quad . \quad$.

19 Energy Balance of an Energy Conversion Process . $\quad$ • $\quad 42$ 


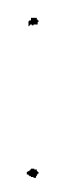




\section{$\underline{\text { TABLES }}$}

1 Possible Solar Central Receiver Plant Development Schedule . . . . . . . .

2 Cooling Water Requirements . $\quad . \quad$. $\quad . \quad 20$

3 Major Cost Summary for Optimized Cooling Tower System • • 28

4 Typical Water Consumption Data for Alternative

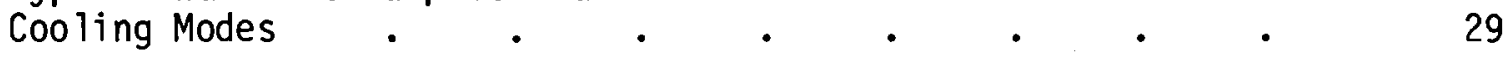

5 Scenarios of Energy Consumption . $\quad . \quad \ldots \quad$. $\quad . \quad 31$

6 Comparisons of 1985 Supply Estimates . . . . . . 34

7 Comparisons of 2000 Supply Estimates $\quad$. $\quad$ • $\quad . \quad . \quad 35$

8 Comparisons of 2020 to 2025 Supply Estimates . . . . 35

9 Projections of Energy Supply from Alternative Energy Technologies

Projections of Energy Supply from Alternative Energy
Technologies, Based on Hudson Institute Study . . . $\quad 39$

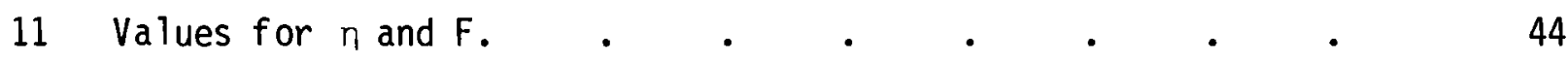

Percentage of Geothermal Energy Consumption Utilized by
Electric Utilities...$\quad$. . . . . 45

\begin{tabular}{l} 
Percentage of Solar Energy Consumption Utilized by \\
Electric Utilities. \\
\hline
\end{tabular}

$14 \begin{aligned} & \text { Percentage of Solar Electric Generation Due to } \\ & \text { Selected Technologies . . . . . . . . } 46\end{aligned}$

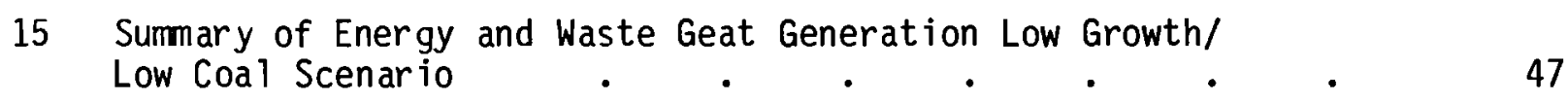

16 Surmary of Energy and Waste Heat Generation Intermediate Growth/Populist Scenario $. \quad . \quad . \quad . \quad . \quad$. 


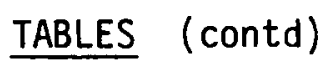

17 Sumary of Energy and Waste Heat Generation Intermediate Growth/Establishment Scenario . . . .

18 Summary of Energy and Waste Heat Generation High Growth/High Coal Scenario

19 Distribution of Cooling Requirements Low Growth/Low Coal Scenario

20 Distribution of Cooling Requirements Intermediate Growth/ Populist Scenario . . . . . . .

21 Distribution of Cooling Requirements Intermediate Growth/

Establishment Scenario . . . . . .

22 Distribution of Cooling Requirements High Growth/High Coal Scenario

23 Energy Production Requiring Dry Cooling . • • . 62

24 Water Consumption as a Percentage of Available Surface Water to Convert Coal to an Equivalent $5.8 \times 10^{12} \mathrm{Btu} /$ day of Product.

25 Water Consumption to Convert 011 Shale to $1 \times 10^{6}$ barrels/ day of Synthetic Crude . $. \quad . \quad . \quad . \quad$. 


\section{INTRODUCTION}

According to projections made by the Department of Energy (DOE 1979) the United States is going to require a primary energy supply of 125 Q (quadrillion Btu) by the year 2000 and 169 Q by 2025. Comparing these projections with the 1977 energy supply of 80 Q, it is apparent that massive increases in energy production will be required.

Due to this energy demand along with efforts in the United States to become energy independent, numerous advanced energy generation technologies are being developed. These development programs are investigating the potential for turning into useful energy the thermal energy that is stored in the earth, as well as the energy available from the sun, wind, waves, tides and falling water. Other programs involve the conversion of more abundant resources, such as coal, into energy forms that are more readily used or are environmentally acceptable.

Although many advanced energy technologies have been investigated for filling the energy supply and demand gap, including fuel cells, thermionic converters, and fusion, the following are technologies that have potential for supplying energy in the not-too-distant future:

- solar

- geothermal

- coal gasification

- coal liquef action

- clean solid fuel from coal

- oil shale.

Associated with the development of these technologies is the use of water to satisfy cooling requirements.

The following report discusses the various technologies with the purpose of analyzing the waste heat generation characteristics, possible means of rejecting this waste heat, and the incentives and potential for using dry or wet/dry cooling. To achieve these objectives this report has been written with five sections plus a section highlighting the major conclusions. The first 
section (following the conclusions) provides background information on the various advanced energy technologies that are likely to require significant cooling. Next, a section discussing the various cooling options that have potential for satisfying these cooling needs and the water consumption characteristics of these options has been provided. The third section uses the available energy projections to indicate the amount of energy that is likely to be produced by the various technologies and to develop projections of the amount of waste heat that might be associated with the projected level of development. The energy projection that has been used as the primary forecast in this report is the study performed by the Hudson Institute (HI) (Candela et al. 1975 and 1977). The reason for selecting this study as a basis is that it considers alternative energy sources in some detail. The fourth section discusses the incentives for using dry cooling that generally apply to all the technologies. The final section presents specific characteristics of each technology and discusses how these characteristics affect the potential use of dry cooling. Based on this information, and the information presented in the first four sections, an estimate of the magnitude of the energy production that might require dry cooling is computed.

The information contained in this report has been obtained from a review of the pertinent literature. Based on this information suitable calculations were performed to allow projections of the potential dry cooling requirements for the advanced energy technologies. 


\section{CONCLUSIONS}

The analysis of the advanced energy generation systems, the potential for using dry cooling, and the waste heat generation characteristics of the advanced technologies results in the following conclusions:

- The magnitude of the waste heat expected to be generated indicates the following percentages of total cooling requirements would be needed by advanced energy technologies:

a. $1 \%$ to $2 \%$ in 1985

b. $17 \%$ to $40 \%$ in 2000

c. $24 \%$ to $76 \%$ in 2025

- Dry cooling could be required for flashed steam and dry steam geothermal plants if balancing withdrawal and reinjection of the geothermal fluid becomes a requirement.

- Binary cycle geothermal plants and plants using the hot dry rocks geothermal resource are even more likely to require dry cooling since these plants will need an outside source of water.

- Solar central tower plants have a high potential for the use of dry cooling since they are likely to be located in the Southwest where water availability problems are already apparent.

- The high water consumption associated with the projected synthetic fuel production levels indicates that dry cooling will be desirable, perhaps even mandatory, to achieve a high level of synthetic fuel production.

- In the year 2000, between 2.5 and $13 \mathrm{GW}$ of electrical energy produced by advanced power generation systems may require dry cooling.

- In the year 2025, this requirement may increase to between 4.5 and $81 \mathrm{GW}_{\mathrm{e}}$. 


\section{ADVANCED ENERGY TECHNOLOGIES}

The following section gives brief descriptions of the advanced energy technologies that are likely to provide a significant amount of energy in the foreseeable future. Only the aspects of the various technologies where cooling is likely to be required have been discussed in detail.

\section{SOLAR ENERGY}

Solar energy can be utilized in a variety of ways. Only the methods used to generate electricity will be considered since these will be the only energy generation techniques requiring extensive cooling.

The four primary solar electric generation technologies currently being pursued are:

- solar thermal

- ocean thermal

- photovoltaics

- wind energy.

Only the solar thermal power plants are likely candidates for dry cooling towers. Ocean thermal energy conversion plants (OTEC) by their very nature will not require dry cooling since these plants will rely on the cool ocean water as a heat sink. Photovoltaic and wind energy systems involve the relatively direct conversion of sunlight or wind energy to electricity and will require essentially no cooling.

Several types of solar thermal plants have been designed. Figure 1 (Bereny 1977) is a schematic of a central tower thermal electric plant. This arrangement is quite similar to a conventional nuclear or fossil fueled plant except that the heat source has been replaced by a solar collector field, and a means of storing the thermal energy has been provided. Storage is optional, but it does extend the time that the plant is available for power generation. The heliostat field consists of an array of independently steerable mirrors that are operated to reflect incident sunlight to the receiving tower, which in turn results in extremely high concentration of the solar energy. A 


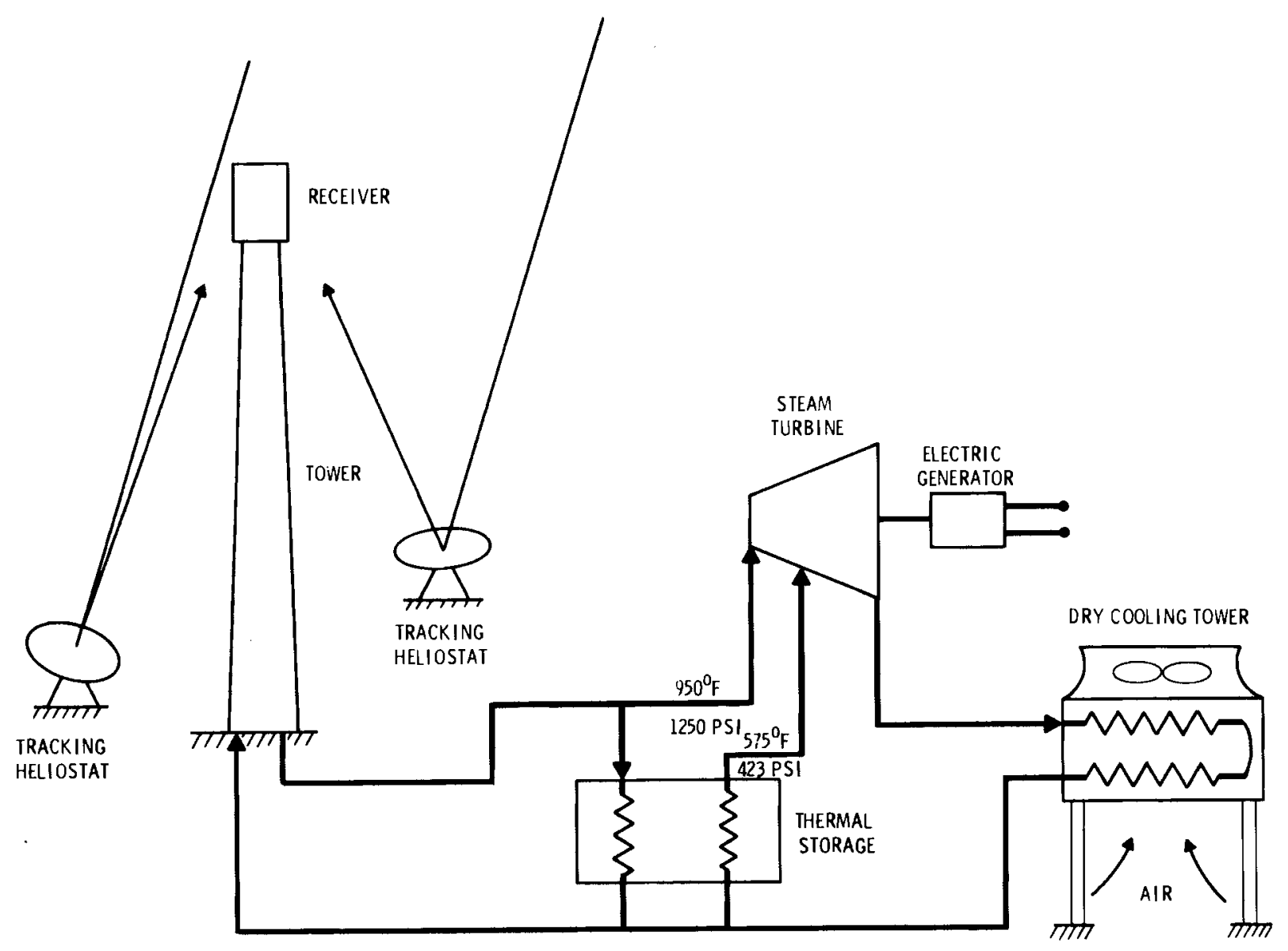

FIGURE 1. Simplified Schematic of a Solar Central Tower Power Plant

working fluid passed through the focal point can be heated to high temperatures. Consequently, these kinds of plants are predicted to have thermal efficiencies in the range of $30 \%$ to $40 \%$. This means that the amount of cooling required for these plants will be comparable to present-day nuclear or coal fired plants for a given amount of electricity generated.

A study by Vant-Hull (1977) has also investigated the possibility of using liquid sodium. In this design, the liquid sodium would be circulated between the central receiver and the thermal storage medium. This results in a receiver design that is more efficient due to the superior heat transfer characteristics of liquid sodium. The power cycle would still be a steam/water 
power cycle utilizing the high temperature liquid sodium to generate steam. Since the power cycle is the common water/steam rankine cycle the potential for wet cooling has not been obviated.

Another method for solar energy collection is the dispersed parabolic trough collector system. This system requires that the solar energy be collected in an array of movable troughs (for tracking purposes) that have a parabolic cross section. Due to the shape of the trough the solar energy is concentrated on a line. Pipes are placed upon these lines of focus and a working fluid is passed through the pipes to be heated. A tracking device is required so that the focused sunlight always intercepts the pipes. These systems are not likely to be as efficient as the central tower concept, because the line focusing of the sun's rays rather than a point focus leads to lower temperatures. This system also suffers from heat loss from the pipes as the working fluid is transported back to the power plant. Efficiencies on the order of $15 \%$ to $20 \%$ are expected (Backus and Brown 1976).

Fixed mirror concepts and solar ponds are also being investigated. The fixed mirror system is similar to the parabolic trough design except the mirrors are built into the ground and are immovable. Tracking is accomplished by moving the absorbing pipe. Solar ponds involve constructing large shallow ponds to absorb the thermal energy. Since only relatively low temperatures will be achieved, thermal efficiencies of around 5\% to $15 \%$ could be expected (Backus and Brown 1976).

The most likely solar thermal electric concept to be used is the central power plant. The study by Bennington et a1. (1978) states that "a principal solar thermal system for electric utilities is the central receiver concept..." The National Science Foundation has chosen the central receiver design for top priority (Backus and Brown 1976). Based on a comparative technical and economic assessment of the alternative solar and conventional system concepts, the solar central receiver plant appeared to be economically competitive and was identified as the preferred system in an Aerospace Corporation study (1975). The Federal Government is pursuing most vigorously the central receiver concept. According to Caputo and Truscello (1976): "It is presently 
considered to be the most advantageous system for electric power generation since it shows an economic advantage of at least $20 \%$ compared to other choices using solar thermal energy."

Depending on the level of effort devoted to the development of solar power plants, commercialization may occur in the 1985 to 2000 time frame. Table 1 indicates a possible development schedule (Bennington et al. 1978). Caputo and Trusce110 (1976) state that commercial plant startup by 1990 with greater than $5 \%$ commercial power production by 2000 is the time frame of interest.

\section{TABLE 1. Possible Solar Central Receiver Plant} Development Schedule

\begin{tabular}{|c|c|c|c|c|c|c|c|c|}
\hline \multirow{2}{*}{$\begin{array}{c}\text { System } \\
\text { Description }\end{array}$} & \multicolumn{3}{|c|}{ Pilot System } & \multirow{2}{*}{$\frac{\text { Early }}{\text { Size }}$} & \multicolumn{2}{|c|}{ Commercial System } & \multicolumn{2}{|c|}{ Ultimate System } \\
\hline & Size & Year & Cost & & Year & Cost & Size & $\cos t$ \\
\hline $\begin{array}{l}\text { Solar Thermal } \\
\text { Central Receiver } \\
\text { c.f. }=0.5(\mathrm{a})\end{array}$ & $10 \mathrm{MW}$ & 1981 & $4000 \$ / \mathrm{kW}$ & $100 \mathrm{MW}$ & 1986 & $2300 \$ / \mathrm{kW}$ & $100 \mathrm{MW}$ & $1400 \$ / \mathrm{kW}$ \\
\hline $\begin{array}{l}\text { Solar Thermal } \\
\text { Central Receiver } \\
\text { c.f. }=0.36 \text {, Fuel } \\
\text { Saver }\end{array}$ & $5 \mathrm{MW}$ & 1978 & $N-A$ & $100 \mathrm{MW}$ & 1990 & $2300 \$ / \mathrm{kW}$ & $100 \mathrm{MW}$ & $860 \$ / \mathrm{kW}$ \\
\hline $\begin{array}{l}\text { Solar Thermal } \\
\text { Combined Cycle } \\
\text { Hybrid, c.f. }=0.5 \text {. } \\
\text { Intermediate }\end{array}$ & & & & $100 \mathrm{MW}$ & 1990 & $1200 \$ / \mathrm{kW}$ & $100 \mathrm{MW}$ & $690 \$ / \mathrm{kW}$ \\
\hline
\end{tabular}

(a) c.f. = capacity factor

\section{GEOTHERMAL}

Electricity generation from a geothermal energy source utilizes the basic steam Rankine cycle. The boiler has been replaced by the steam or hot water that is produced from wells. Three kinds of geothermal resources are either currently being utilized or have significant potential for future utilization: Vapor dominated (or dry steam), hot water (or wet steam), and hot dry rock. At present only the vapor dominated and hot water resources are being used for power generation. 
The vapor-dominated resource is the most desirable since it is characterized by the production of high quality steam from the geothermal wells. Al though it is relatively rare, systems using the dry steam resource have already been commercialized. The Geysers in California is a good example. Figure 2 is a simplified heat balance diagram that is typical of power plants at The Geysers. This $\mathrm{plant}$ has a heat rate of $21,690 \mathrm{Btu} / \mathrm{kWh}$ which translated into a plant efficiency of $16 \%$ (Mathew 1973).

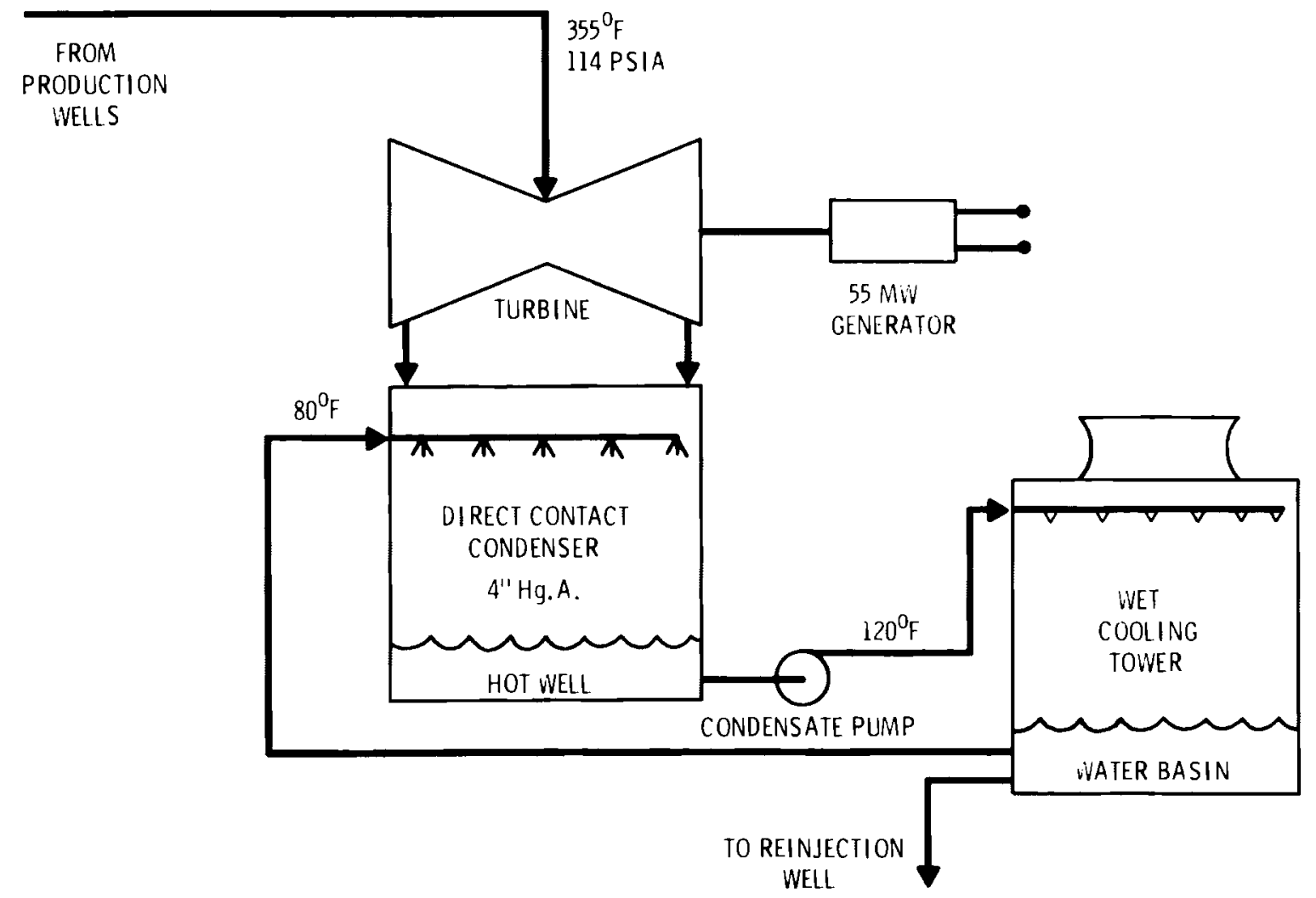

FIGURE 2. Simplified Schematic of a Typical Geothermal Power Plant at The Geysers, California

The hot water resource is 20 times as common as dry steam (University of 0klahoma 1975) but is utilized in much the same way. In the hot water resource, however, a mixture of boiling water and flash steam is produced by the production wells. Consequently, separators and/or flash tanks must be 
provided to allow further flashing of the water and to separate the water from the steam. The steam is then used in the power plant while the water is sent to a reinjection wel1. Figure 3 (Robertson 1978) indicates a possible configuration for this kind of power plant. The resource is usually at a lower temperature and consequently the efficiency for these kinds of plants is lower, on the order of $12 \%$.

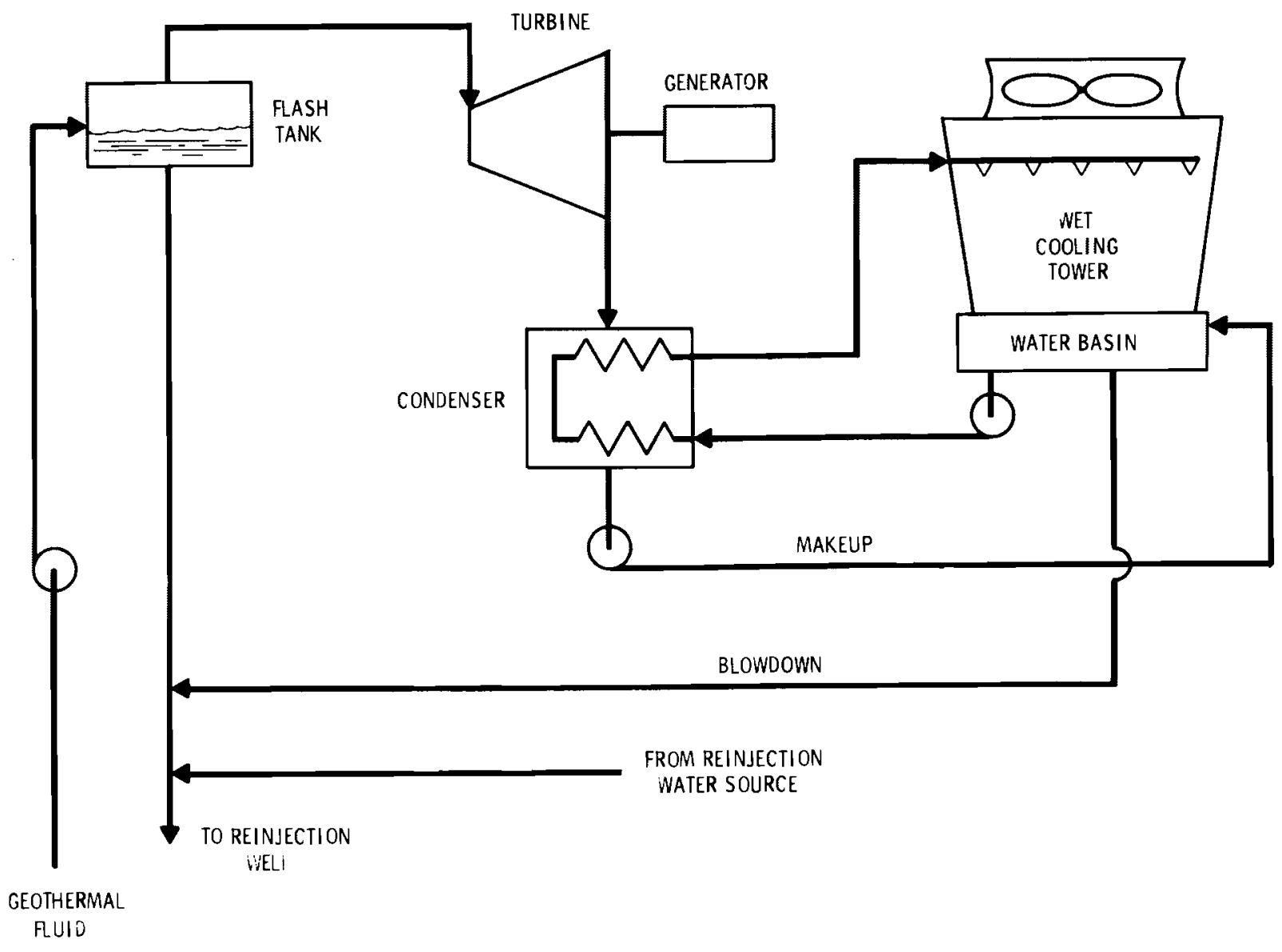

FIGURE 3. Flashed Steam Geothermal Plant

Hot water resources are being utilized for electricity production in a number of countries including New Zealand, Mexico, Japan, Iceland, El Salvador, and Philippines (Jónsson 1976). At present the hot water resources in the U.S. 
are not being extensively utilized although development work is being conducted. Rex (1978) reports that the first commercial hot water/wet steam facility will probably be the 48-MW plant under construction by Republic Geothermal in the East Mesa field in the Imperial Valley of California. The second commercial wet steam plant is likely to be a 50-MW plant near Milford, Utah. This plant is a joint venture of Phillips Petroleum Co., and Rogers International.

Techniques to utilize the hot dry rock resource are currently under development. This resource is characterized by a subterranean region of hot rock with little or no water available. Utilization of this resource will require fracturing of the rocks (hydraulic and nuclear methods have been proposed) and pumping water down to the fractured zone. The resulting hot water or steam * will be withdrawn and used in power plants similar to the plants already discussed. Hot dry rock resources are relatively abundant, but development of the necessary technology will probably cause the development of this resource to lag behind (Maslan et al., 1975).

When the geothermal resource is of low quality, that is, highly saline, contains large quantities of noncondensable gases, or is at too low a temperature to justify flashing, it is frequently suggested that a binary cycle plant be used. These kinds of plants are currently under development. Figure 4 is a schematic of a design that was studied for the site at Niland, California. This particular plant has a reported thermodynamic efficiency of $16.5 \%$. This relatively high efficiency is due to the high resource temperature of 228 !C. The reason for using a binary cycle in this case is the high concentration of solids in the geothermal fluid; it consists of approximately 250,000 ppm or about $1 / 4$ solids (Robertson 1978).

It has also been suggested that the total water/steam flow could be accelerated to high speed through a converging/diverging nozzle. This flow would then be directed to the vanes of an impulse turbine (University of Oklahoma 1975) (somewhat analogous to a water wheel). This process will require the development of nozzles and turbines that can operate under two-phase flow conditions and withstand the corrosion problems associated with high-salinity geothermal brines and the erosion problems caused by the high fluid velocities. 


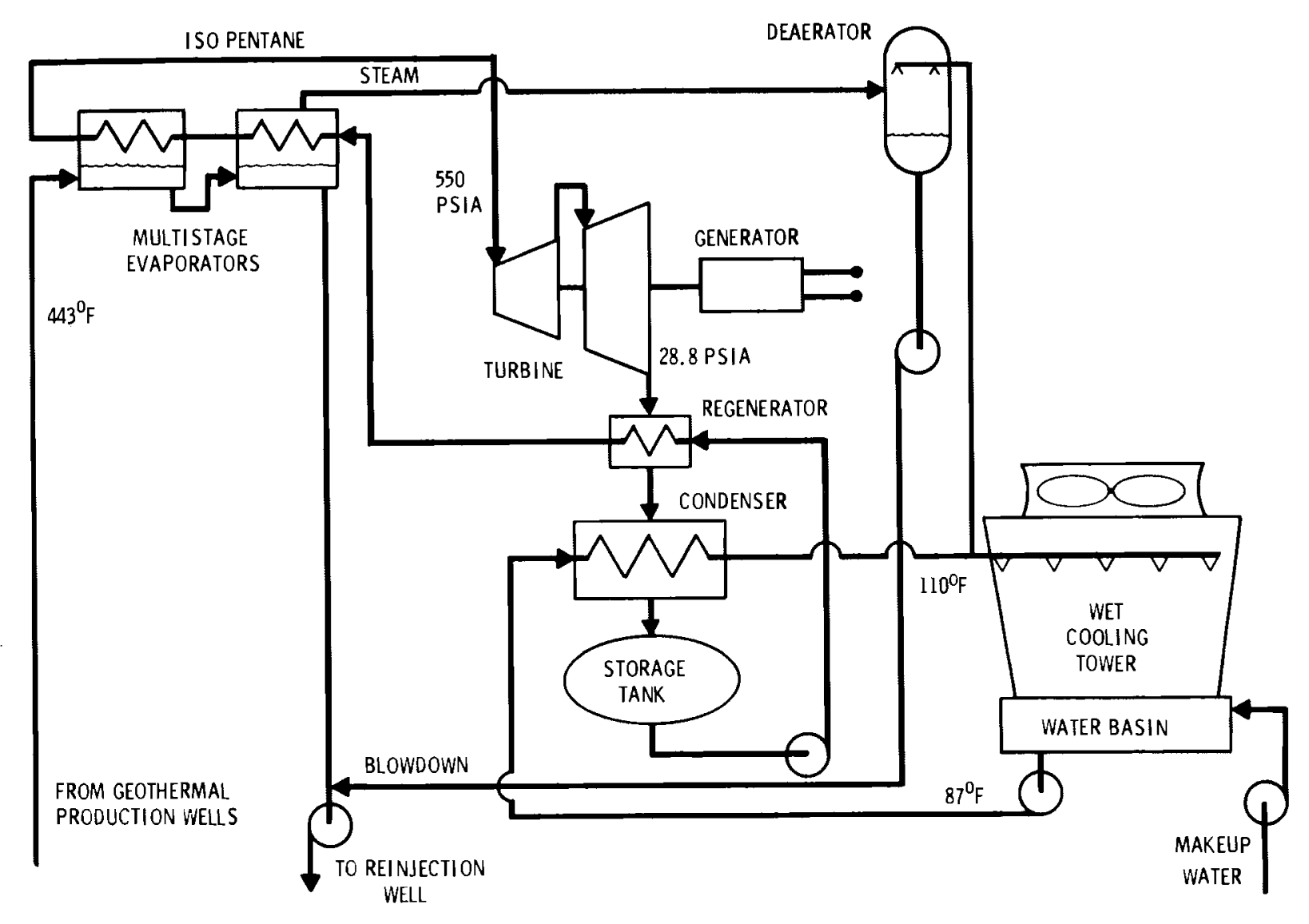

FIGURE 4. Simplified Schematic of a Multistage Evaporation Binary Cycle Geothermal Power Plant

The amount of heat rejection associated with any geothermal power plant is significant because of the low plant efficiencies. For example, Ermak (1977) has reported geothermal plant efficiencies in the range of $8 \%$ to $18 \%$. Systems using a $190^{\circ} \mathrm{C}$ resource have efficiencies of $8 \%$ to $11 \%$, while plants using a resource at $285^{\circ} \mathrm{C}$ have efficiencies of $13 \%$ to $17 \%$. These efficiencies are significantly lower than a nuclear or fossil fueled power plant. They are in the range of one-half to one-fourth of a typical nuclear plant with an efficiency of $32 \%$. Consequent $1 y$, for a given amount of electricity produced, a geothermal plant rejects two to six times as much heat as a comparably sized nuclear plant, since $Q=E_{\text {out }}(1 / n-1)$. 


\section{SYNTHETIC FUELS}

Synthetic fuels include low (approximately 100 to $200 \mathrm{Btu} / \mathrm{ft}^{3}$ ), intermediate (approximately 300 to $650 \mathrm{Btu} / \mathrm{ft}^{3}$ ), and high (approximately 900 to $1050 \mathrm{Btu} / \mathrm{ft}^{3}$ ) Btu gas from coal, liquids such as oil from coal and oil shale, and solid fuels from coal. A variety of processes have been suggested or are being developed to form these products. Figure 5 (Probstein and Gold 1978) illustrates the varity of methods available. The impetus for forming synfuels is that vast oil shale and coal resources in the United States can be converted to replace products that are in limited supply or to provide fuels that are more environmentally acceptable. Water is used in a variety of places in the conversion processes; primarily, it is used for cooling although in the oil shale technologies spent shale disposal may require the highest water consumption.

A number of conversion processes have been developed for producing gas from coal. These processes include the Lurgi, HYGAS, BI-GAS, Synthane, and $\mathrm{CO}_{2}$ acceptor processes for producing high Btu gas. Low and intermediate Btu gas production process include the Lurgi, Koppers-Totzek, Bureau of Mines Stirred Fixed Bed, Westinghouse Fluidized-Bed Gasifier, and the Ash Agglomerating Fluidized-Bed Gasifier (University of OKlahoma 1975). While there are a great number of processes available, they all rely primarily on variations of the following four subprocesses (Harrington et al. 1977):

- gasification

- gas purification

- shift conversion

- methanation.

The first and last subprocesses are where methane $\left(\mathrm{CH}_{4}\right)$ is actually produced. The other processes serve to remove harmful or useless components of the gas and prepare the gas for the methanation step.

In the gasification step, coal, steam, oxygen (or air in the case of low Btu gasification) and possibly hydrogen are combined to produce low or intermediate Btu gas. This gas consists primarily of carbon monoxide (CO), carbon dioxide $\left(\mathrm{CO}_{2}\right)$, hydrogen gas $\left(\mathrm{H}_{2}\right)$, and a small amount of methane. Figures 6 


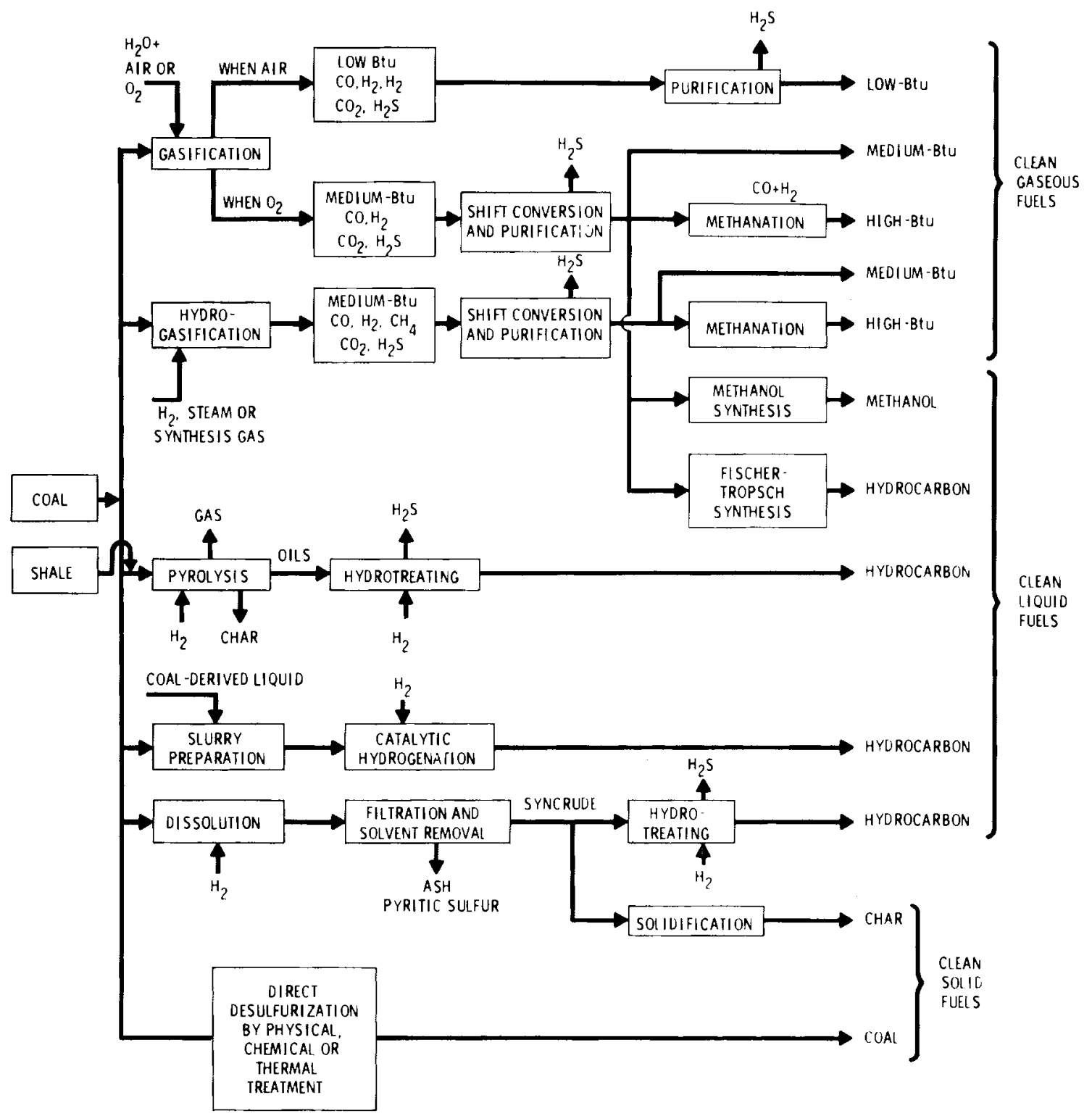

FIGURE 5. Possible Methods of Producing Synthetic Fuels

and 7 are flow diagrams for two of the proposed pipeline gasification processes (Probstein and Gold 1978). These figures indicate where water is used and where cooling is required. 


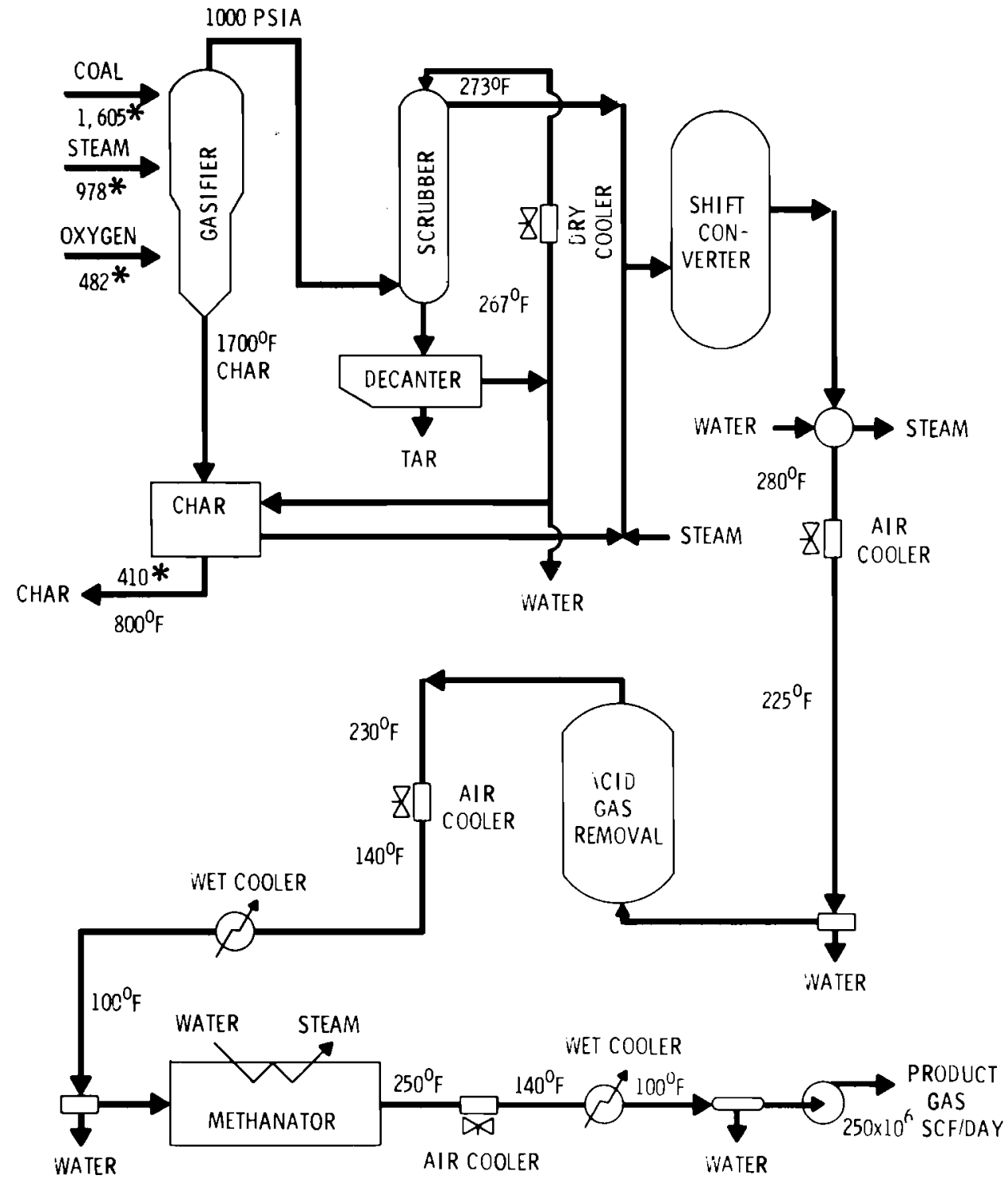

* flow rates in $10^{3}$ LBHR

\section{FIGURE 6. Simplified Flow Diagram for a High Btu Coal Gasification Plant Based on the Synthane Process}

The production of synthetic crude from coal can be achieved by the following three methods (University 0k1ahoma 1975):

- catalytic conversion

- hydrogenation

- pyrolysis. 


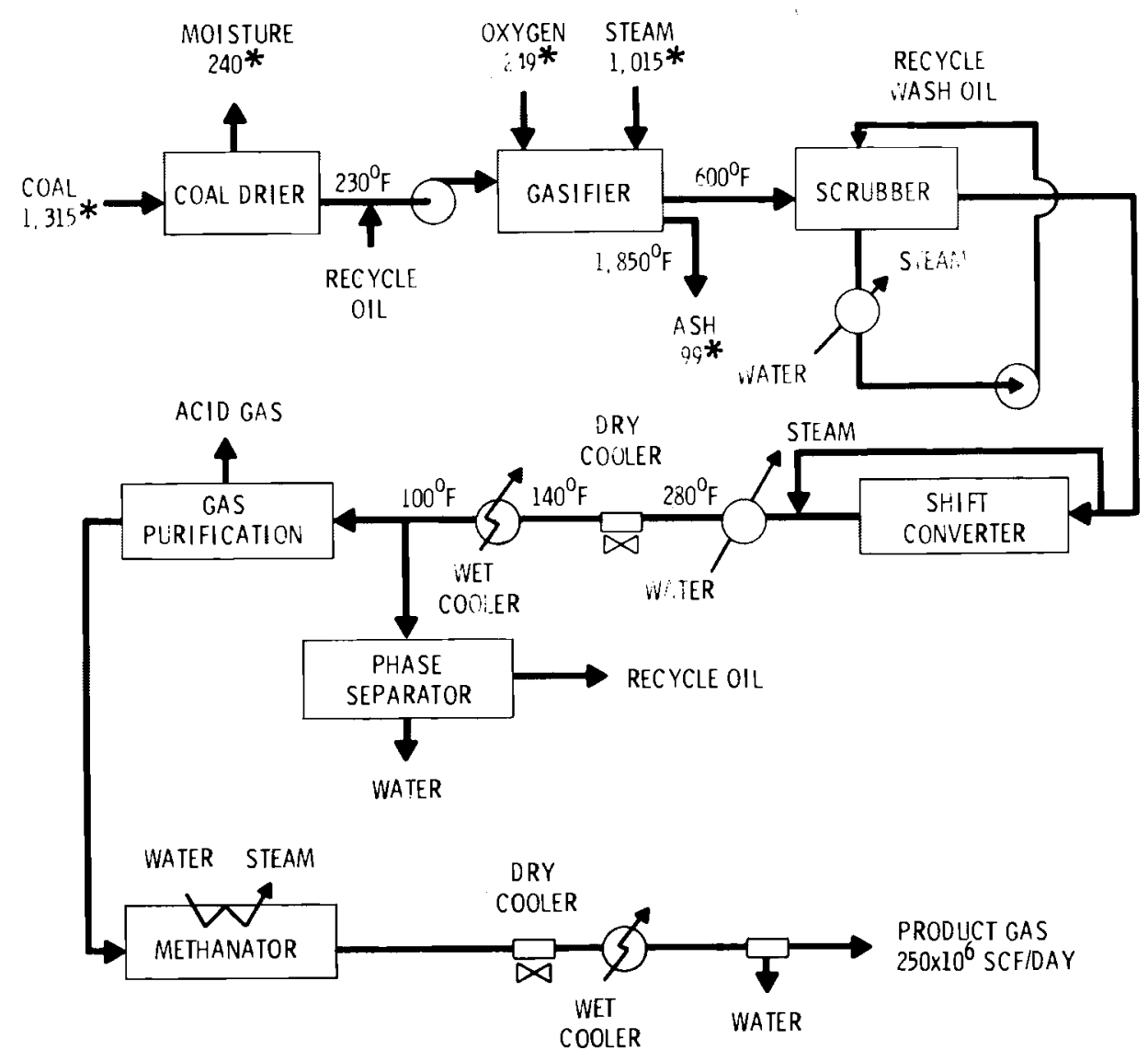

* FLOW RATES IN $10^{3}$ LB/HR

FIGURE 7. Simplified Flow Diagram for a High Btu Coal Gasification Plant Based on the Hygas

Process

Based on these three basic methods a variety of processes have been investigated including the Synthoil, H-Coal, Solvent Refined Coal, Consol Synthetic Fue 1, COED, TOSCOAL, and Fischer-Tropsch processes (University of Ok lahoma 1975).

In the catalytic conversion method, intermediate Btu gas is formed and then combined with hydrogen and carbon monoxide in the presence of a catalyst to produce the liquid fuel. This step is followed by a purification and shift conversion step before the actual liquefaction step takes place. In the hydrogenation method, hydrogen is reacted with the coal either as a gas in the presence of a catalyst or in the form of a hydrogen-rich solvent. Pyrolysis requires 
that the coal be heated in the absence of an oxidizer until it decomposes. This results in the production of gases, char, and a liquid hydrocarbon. Normally, the processes involve one of these liquefaction methods along with a cleaning step for sulfur removal and a step to improve the quality of the product.

A typical coal liquefaction plant flow diagram is shown in Figure 8 (Probstein and Gold 1978). The process shown is based on the Synthoil process being developed by the Pittsburgh Energy Research Center of DOE and will produce low-sulfur fuel oil. A flow diagram indicating a possible method of producing hydrogen in a coal liquefaction plant is shown in Figure 9 (Probstein and Gold 1978).

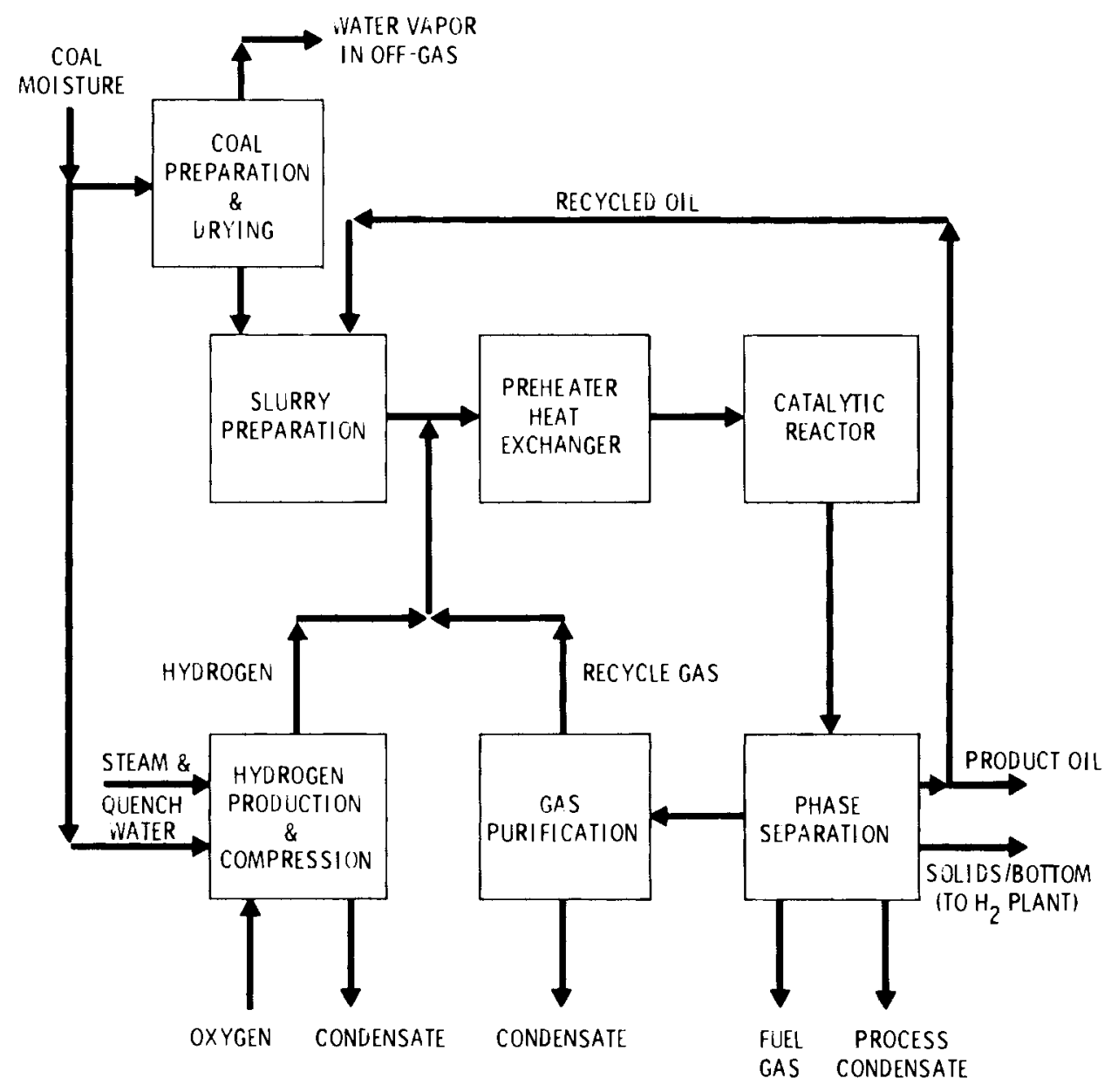

FIGURE 8. Water Streams in a Synthetic 0 il Plant 


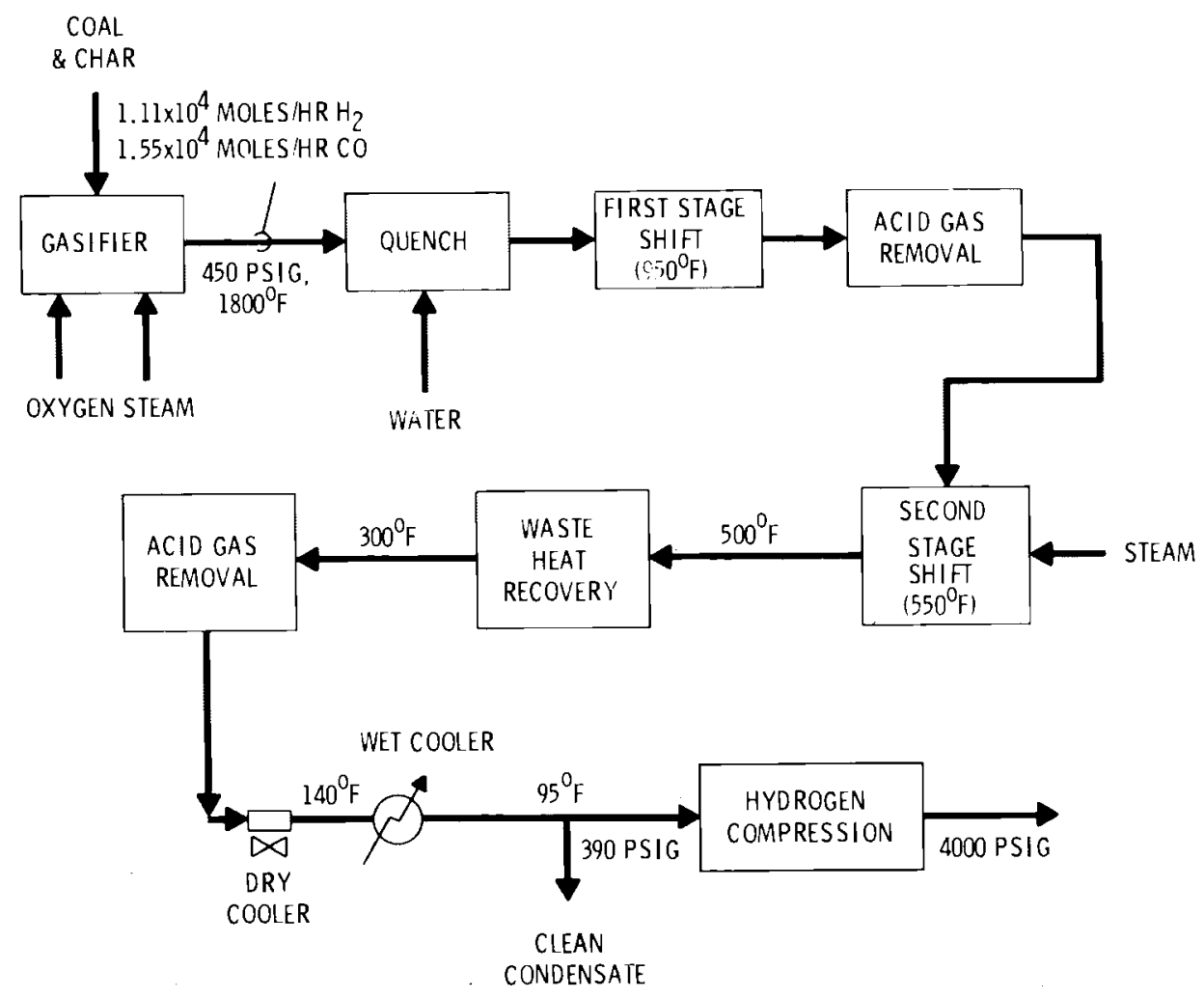

FIGURE 9. Flow Diagram for a Possible Method of Producing Hydrogen During the Production of Synthetic 0 il

The last coal conversion process considered is the conversion of coal to a clean solid fuel. Figure 10 (Probstein and Gold 1978) indicates the primary water streams in a plant designed to produce solvent refined solid fuel. This process is comparable to the solvent refining process for coal liquefaction except the plant is designed to produce primarily a solid fuel.

Liquid fuels are the primary product of oil shale conversion technologies. A flow diagram for an oil shale plant is shown in Figure 11 with a more detailed diagram of the upgrading plant shown in Figure 12 (Probstein and Gold 1978). The method used for production of synthetic liquids from oil shale is the pyrolysis method. The method is analogous to the pyrolysis method used for coal liquefaction except oil shale is used as the feed stock. The pyrolysis reaction is called retorting. It is the choice of retorting technology that distinguishes the major oil shale processing methods. The major surface 


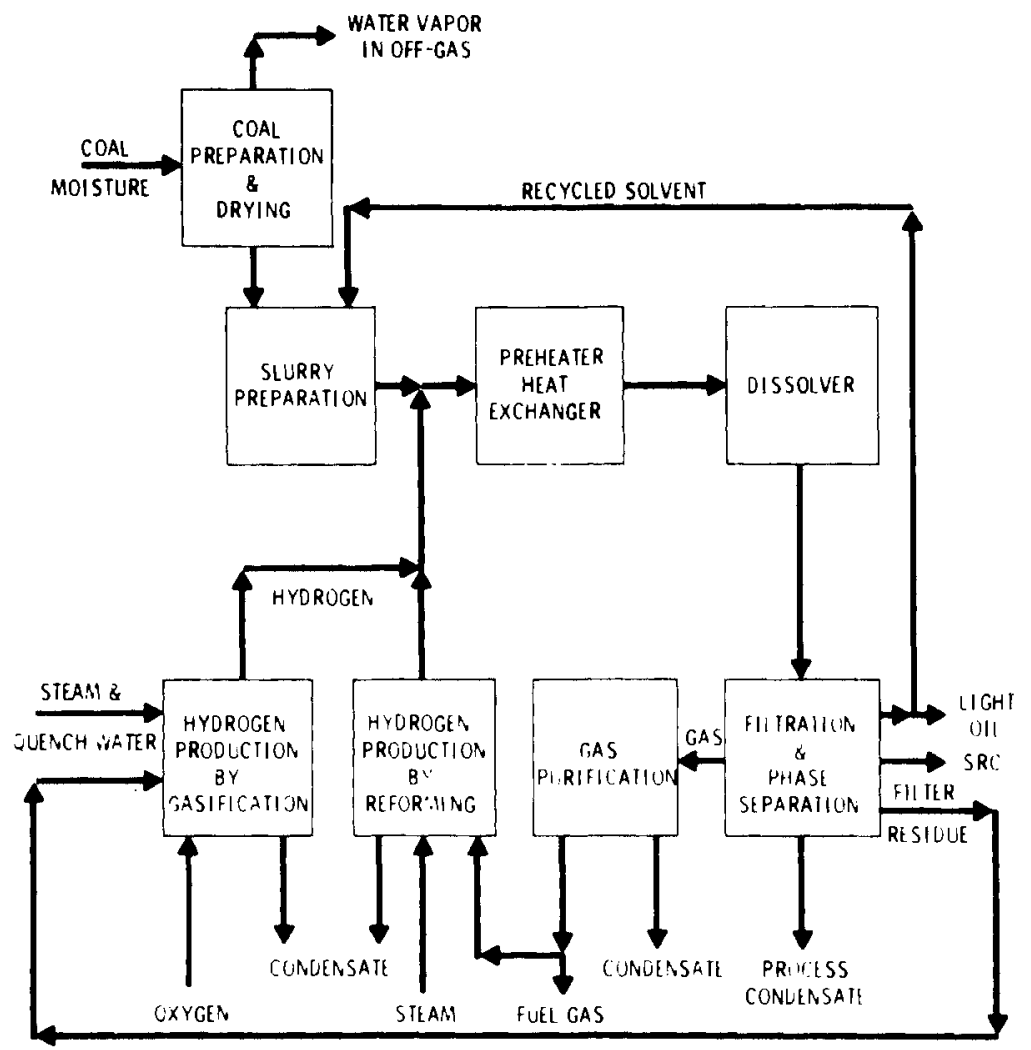

FIGURE 10. Water Streams in a Solvent Refined Solid Fuel Plant

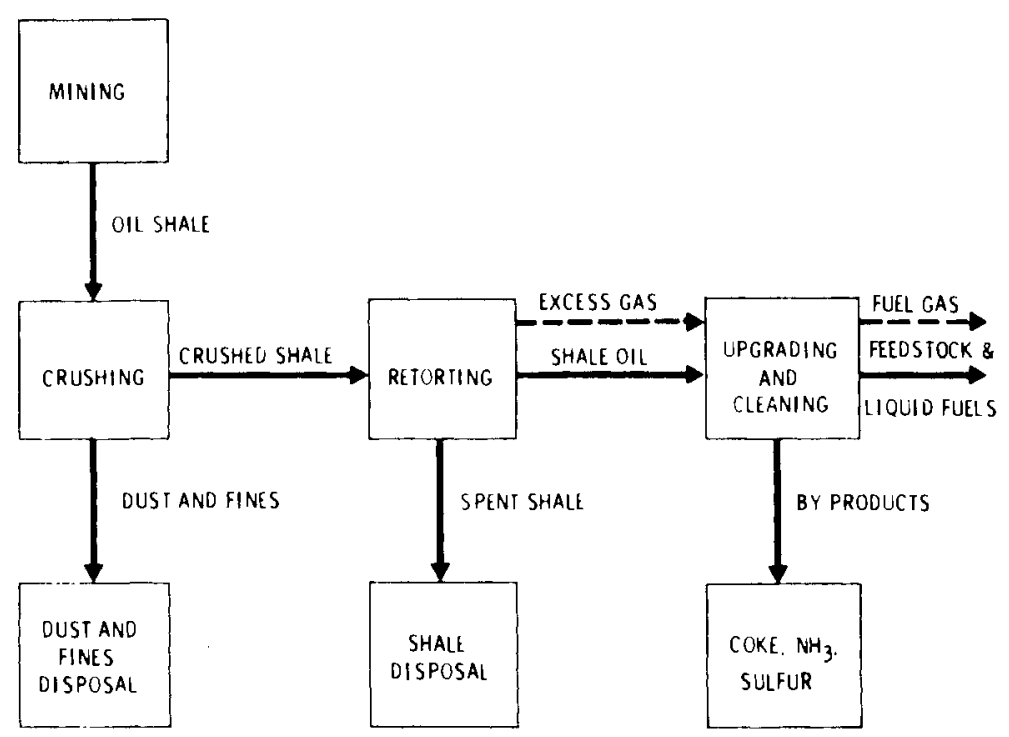

FIGURE 11. Flow Diagram for an 0 il Shale Plant 


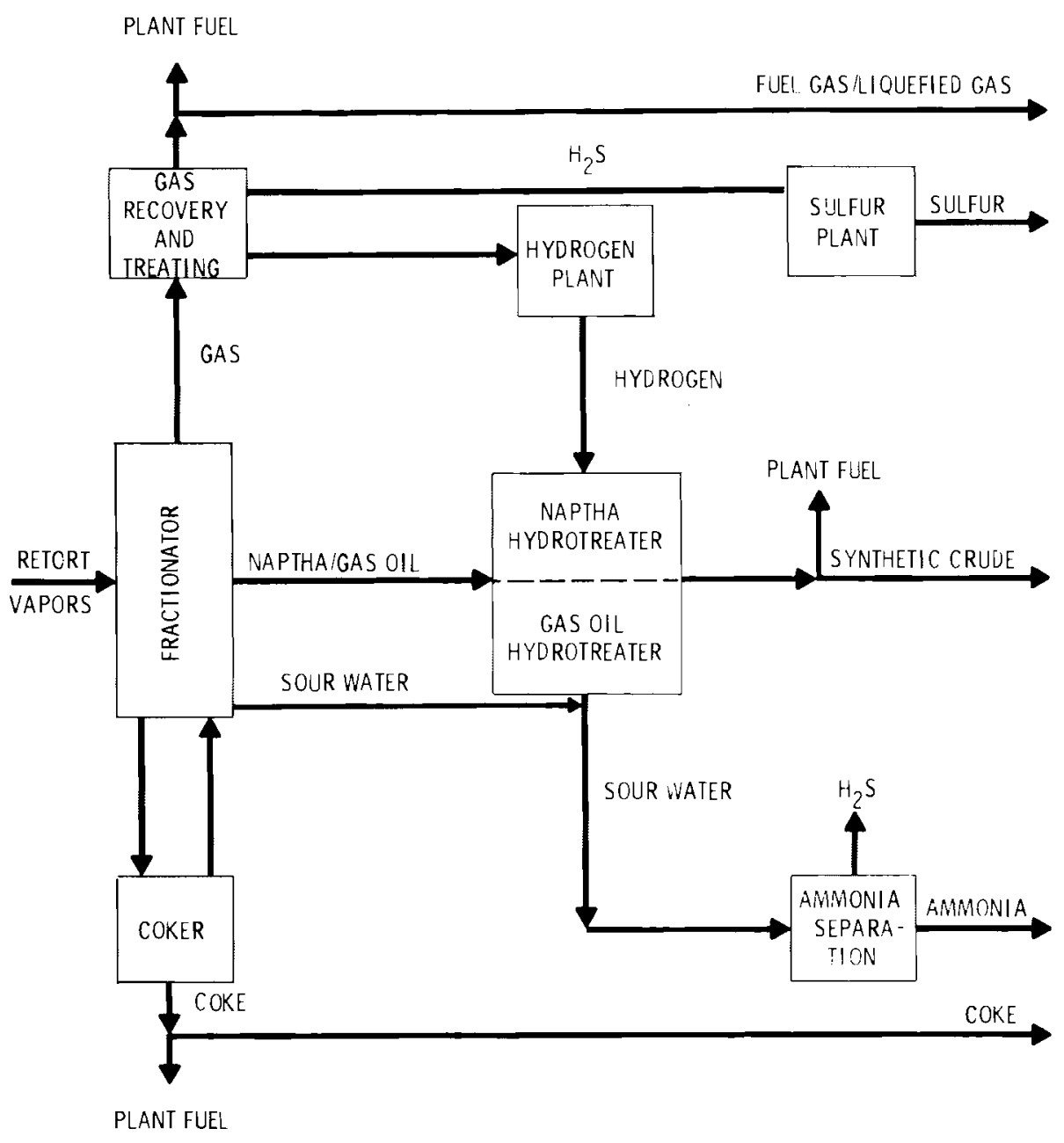

FIGURE 12. Schematic of an $0 i 1$ Shale Upgrading Plant

retorting methods include the Bureau of Mines Gas Combustion, Union 0il "A" and the Tosco II (University of Oklahoma 1975). In situ (underground) retorting includes the Bureau of Mines and the Garrett processes (University of Oklahoma 1975).

Probste in and Gold (1978) have performed an indepth analysis of the various processes being developed for production of synfuels. One result of this study has been estimates of water consumption for the various plants based on different levels of wet/dry cooling. Their results are presented in Table 2. The column, High Wet Cooling, tabulates the expected water consumption for cooling if air coolers are used only when it is clearly cheaper than wet 
cooling, even when water has a low value. This occurs only when cooling high temperature streams, typically above $140^{\circ} \mathrm{F}$. The Intermediate and Minimum Practical Wet Cooling columns indicate the water used for cooling when increasing amounts of dry cooling are used to replace wet cooling.

\section{TABLE 2. Cooling Water Requirements}

\begin{tabular}{ccc}
$\begin{array}{c}\text { Minimum Practical } \\
\text { Wet Cooling, } \\
\text { gal } / 106 \mathrm{Btu}\end{array}$ & $\begin{array}{c}\text { Intermediate } \\
\text { Wet Cooling, }\end{array}$ & $\begin{array}{c}\text { High Wet } \\
\text { Cooling, }\end{array}$ \\
$\mathrm{y}$ & gal $/ 10^{6} \mathrm{Btu}$ & $\mathrm{gal} / 10^{6} \mathrm{Btu}$ \\
\hline
\end{tabular}

\begin{tabular}{|c|c|c|c|}
\hline Synthane & 5.9 to 6.5 & 6.9 to 8.0 & 12.9 to 16.4 \\
\hline Hygas & 5.3 to 5.5 & 6.0 to 6.1 & 11.1 to 11.4 \\
\hline Lurgi & 8.6 to 9.6 & 14.2 to 15.9 & 17.3 to 19.3 \\
\hline \multicolumn{4}{|l|}{ Coal Liquefaction } \\
\hline Synthoil & 7.0 to 8.2 & 7.9 to 9.1 & 12.9 to 15.0 \\
\hline \multicolumn{4}{|l|}{ Clean Coal } \\
\hline SRC & 2.7 to 2.8 & 3.2 to 3.3 & 7.3 to 7.5 \\
\hline \multicolumn{4}{|l|}{0 il Shale } \\
\hline Paraho Direct & --- & 11.6 & -- \\
\hline Paraho Indirect & -- & 13.3 & --- \\
\hline TOSCO II & --- & 8.5 & -- \\
\hline
\end{tabular}

Below 270 to $300^{\circ} \mathrm{F}$ useful heat cannot be extracted from a process stream; therefore, further cooling is needed. The most economic procedure is probably to cool to 130 to $140^{\circ} \mathrm{F}$ with air coolers and below that with wet coolers (Probstein and Gold 1978). There is a tradeoff for a given process depending on the cost of water and money. 


\section{CHARACTERISTICS OF COOLING OPTIONS}

Al1 the energy generation processes considered require cooling in one form or another. The technologies involving electrical generation use cooling primarily to cool the steam condenser. Condensing the steam dramatically increases the power output of the plant. From a thermodynamic standpoint it increases the efficiency of the plant. In a synthetic fuel plant the four kinds of loads that require cooling are: turbine condensers, gas purification, process streams, and gas compressors.

\section{TYPES OF COOLING METHODS}

There are basically four major classes of cooling methods. These are:

- once-through

- cooling ponds and lakes

- wet cooling

- dry cooling.

Wet cooling and dry cooling are further subclassified depending on whether the air flow is naturally or mechanically induced. Dry cooling may also include the use of an intermediate heat transfer fluid such as ammonia. A fifth classification can be identified which is actually a combination of wet cooling and dry cooling, the so-called wet/dry cooling method.

\section{Once-through Cooling}

Once-through cooling simply involves withdrawing water from a water body, circulating it through the condenser, and returning it to the same water body. Figure 13 illustrates the principle. The advantage of this cooling method is the reduced costs for equipment and operation; however, it has a serious disadvantage in that large amounts of heat are dumped into the river or other water body. This can be detrimental to the river ecology. This problem can be alleviated somewhat by proper design of the discharge; however, there are a limited number of sites where this is an acceptable solution. 


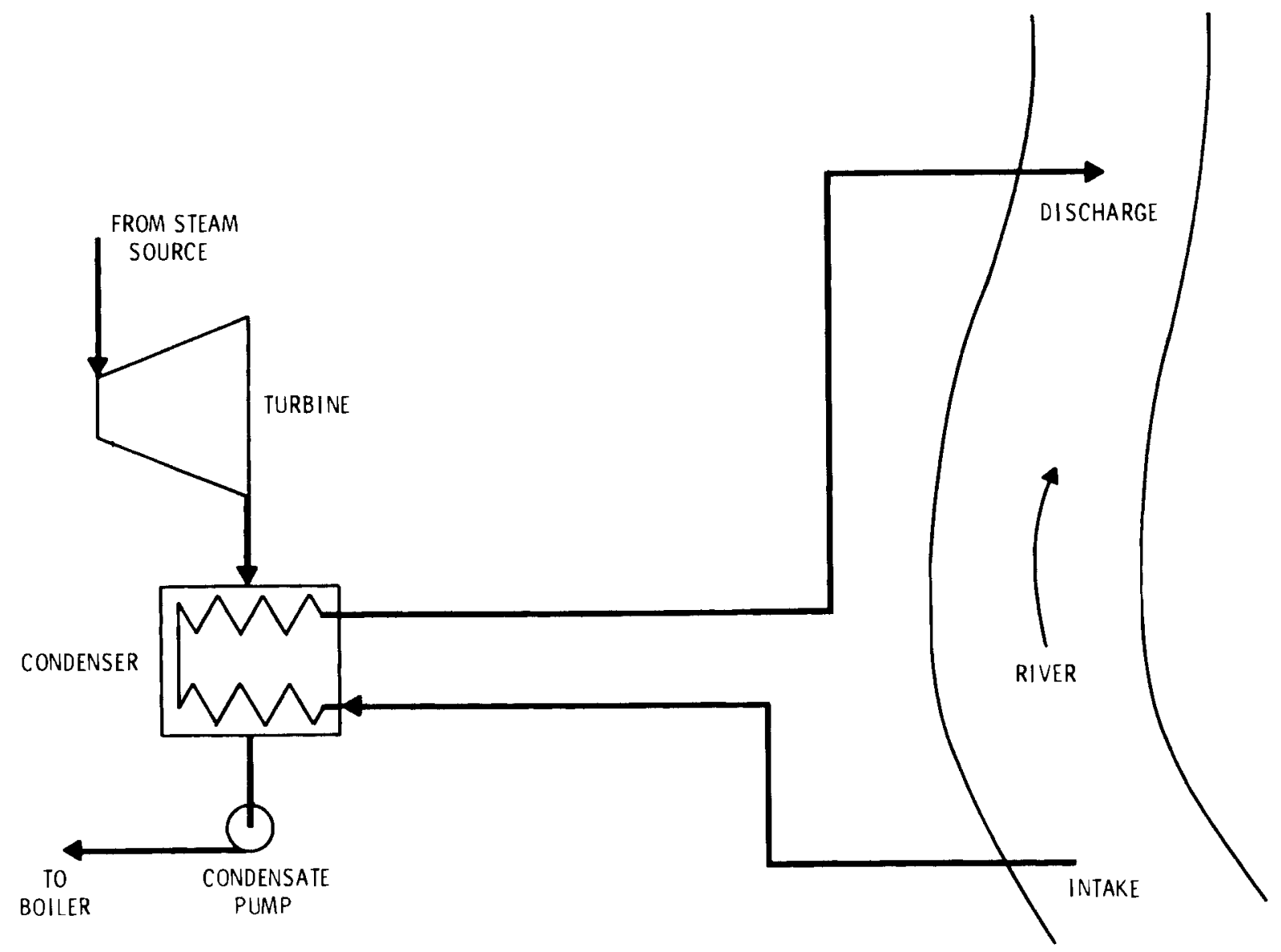

FIGURE 13. Schematic of a Once-Through Cooling System

Cooling Ponds and Lakes

This cooling method is similar to once-through cooling except the water body is constructed. The Environmental Protection Agency has defined cooling lakes as any manmade water impoundments which impede the flow of a navigable stream, while cooling ponds are manmade impoundments which do not impede the flow of a navigable stream (Hendrickson, 1978). Generally, this method is used if the flow in a river at an available site is insufficient for once-through cooling, but there would be enough water to replace what is lost through evaporation from the pond or lake and to control mineral build-up. It is not oncethrough cooling in the pure sense since the water does eventually get recirculated. 
Cooling ponds and lakes have a higher consumptive use of water than oncethrough cooling. This is because the water temperature will be higher due to the limited water available for cooling. Also, cooling ponds require large areas; typically 1 to 2 acres/MW of plant capacity. This amount of land may not be available at a proposed plant site. The pond can be used for other purposes, such as a source for municipal water supply and for recreation (Federa 1 Power Conservation, 1971).

\section{Wet Cooling}

Cooling towers are generally employed when the first two options are precluded due to water supply, land availability, or environmental considerations. Wet cooling towers are the most common type of cooling tower used on new plants at the present time. An example of an evaporative wet cooling tower is shown in Figure 14. The schematic indicates a fan to pull the air through the tower (mechanical draft), although the tower can be designed such that the buoyancy of the heated air in the tower will create a draft in the tower (natural draft). In the wet tower system the cooling water is allowed to flow over fill or packing material that disperses the water into droplets and aids evaporation. Since wet towers rely primarily on latent heat transfer, significant quantities of water are consumed. Also, a certain percentage of the cooling water must be released from the system (blowdown) and replenished (make-up) in order to keep the contaminants in the water from reaching too high a concentration.

Although wet towers do reduce the water withdrawal rate, their consumptive use is much higher; also, the blowdown water increases the salinity of the receiving water. There are other problems associated with wet towers. For example, under certain weather conditions, fogging and icing can be a problem (Cooling w/0 Water..., 1973). Furthermore, the public may regard cooling tower vapor as an eyesore and source of pollution (Crutchfield 1970).

Dry Cooling

Dry cooling towers are being developed to overcome some of the difficulties associated with the previously mentioned cooling options. A dry tower uses large finned heat exchangers that are cooled by air flowing past them. 


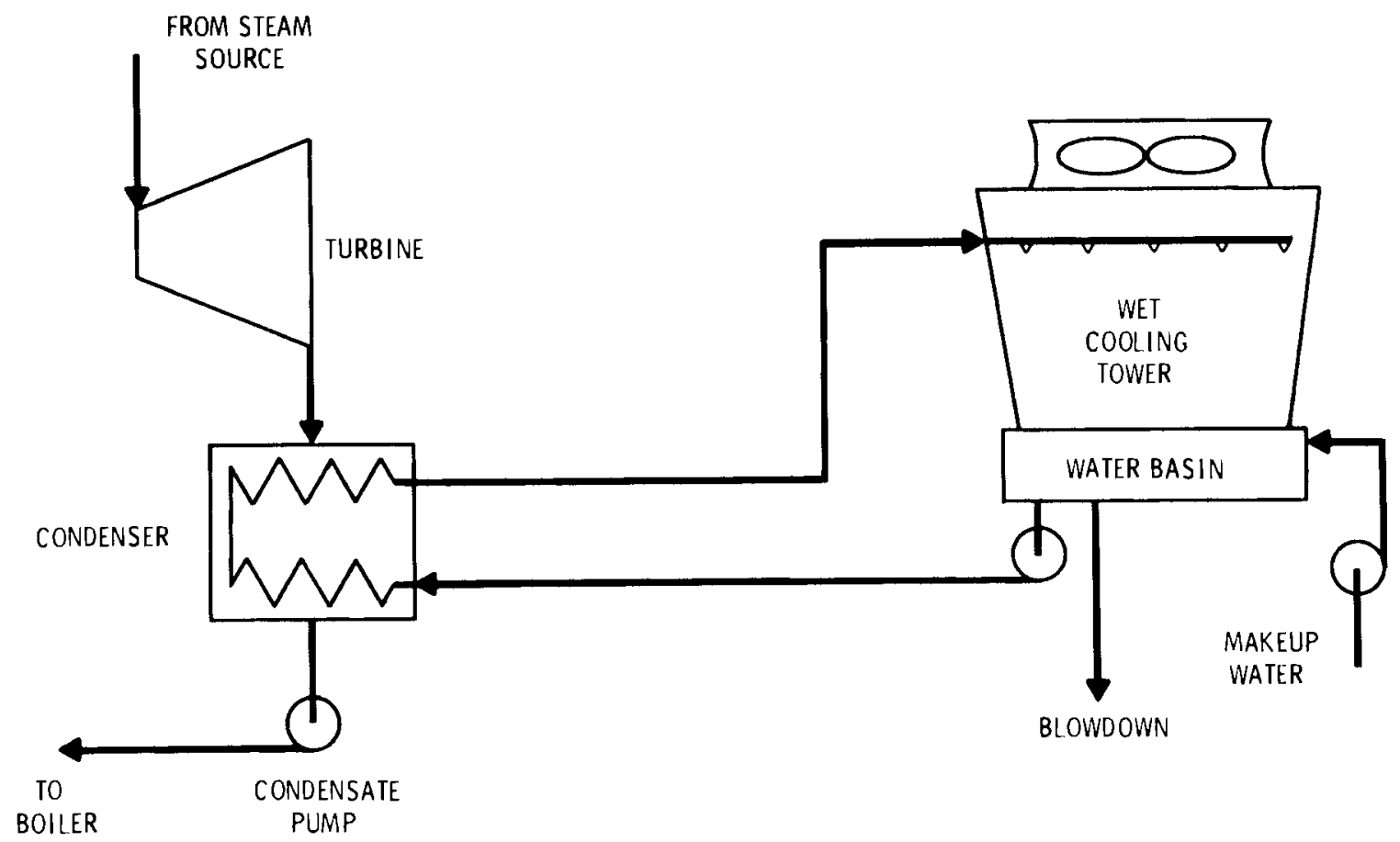

FIGURE 14. Schematic of an Evaporative Cooling System

This method is analogous to the radiator in an automobile. No evaporation occurs, and all the heat transfer is by conduction and convection.

There are two basic types of dry cooling towers: direct and indirect (Figures 15 and 16). The indirect system is similar to a wet tower except that the cooling element consists of large finned cooling coils that do not allow the cooling medium (usually water) to come in contact with the air. In the direct method, the condenser is actually replaced by the dry cooling tower. The steam is condensed directly in the cooling tower. This method requires large steam ducts to the tower. A third dry cooling method is being developed, which involves the use of an intermediate heat transfer fluid. Ammonia is the fluid that is apparently best suited for this application. This system in operation will function much like the direct system. The ammonia, which is vaporized in the steam condenser, is condensed in the dry cooling tower and returned as a liquid. Figure 17 illustrates the ammonia-dry cooling concept. 


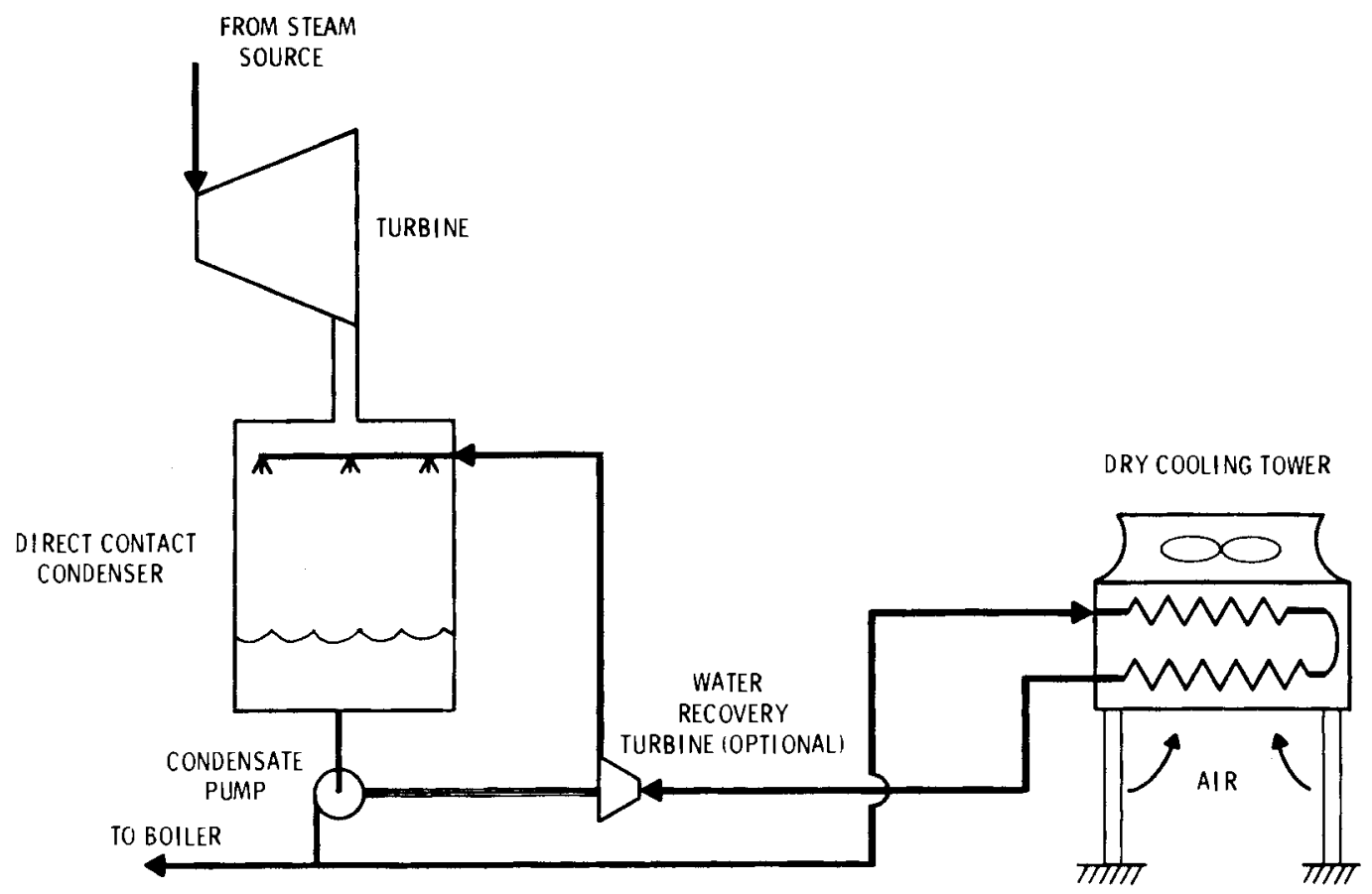

FIGURE 15. Indirect Method of Dry Cooling

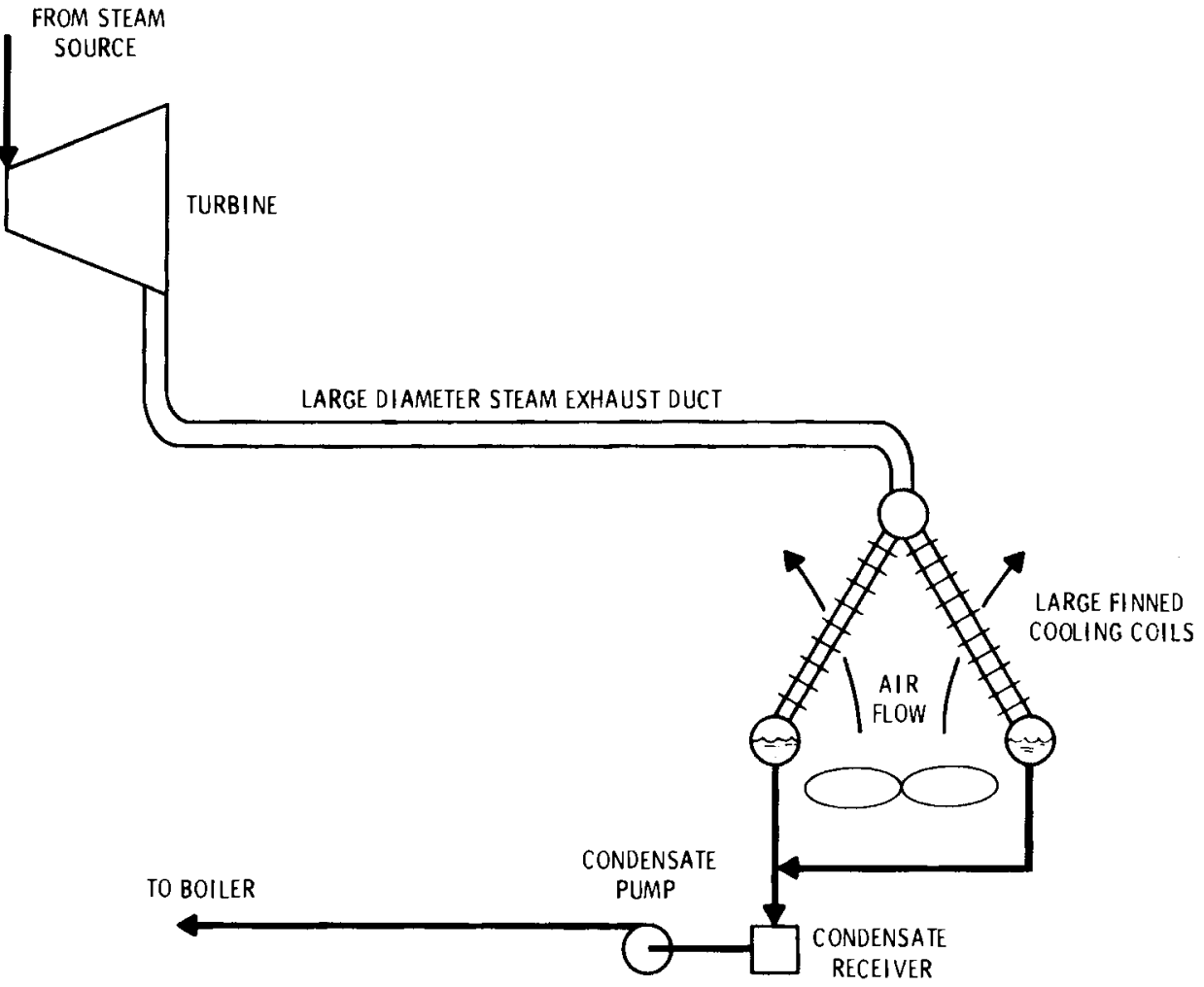

FIGURE 16. Direct Method of Dry Cooling 


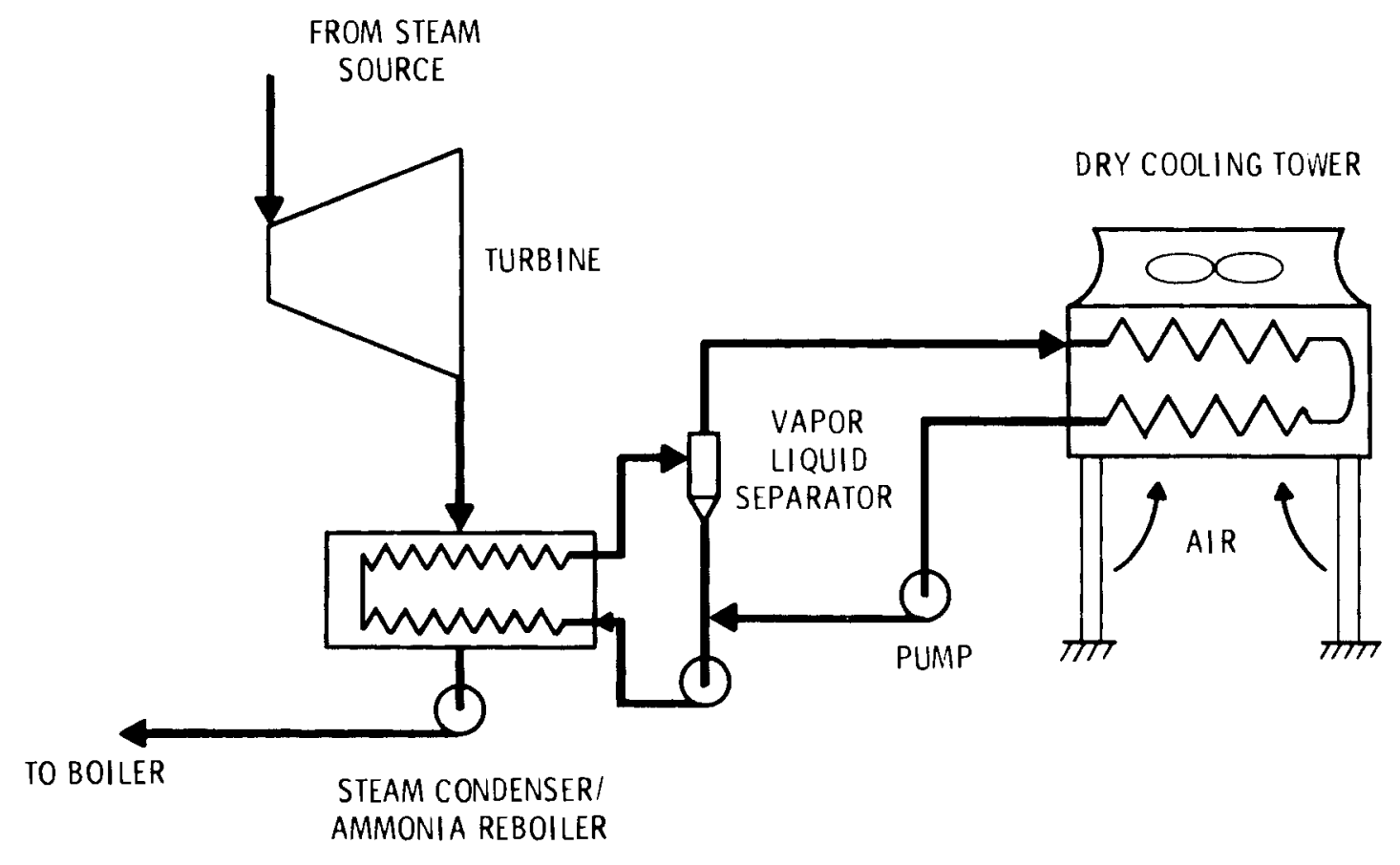

FIGURE 17. Ammonia Dry Cooling

The advantages of using dry cooling include:

- no heat addition to bodies of water

- no icing or fogging problems

- reduced maintenance costs (no chemical additives or periodic cleaning is required)

- plants can be sited without regard for water availability

- additional $\mathrm{plants}$ can be added at sites that may be water constrained

- water consumption is essentially zero

- no pollution problems from cooling tower drift.

The primary disadvantage of dry cooling towers is that the temperature at which they reject heat is dependent on the dry bulb temperature rather than the wet bulb temperature, as in a wet tower. This means that the dry towers must be significantly larger to reject a given amount of heat, which results in high capital expense, and dry towers cannot cool the water to as low a temperature since the dry bulb temperature is generally higher than the wet bulb 
temperature. This places a performance penalty on the power plant; that is, the efficiency will be much lower. Some of these disadvantages are offset in the ammonia system (Alleman et al., 1976) because it:

- makes more efficient use of the available temperature differences - therefore, smaller surface area required -- about $35 \%$ less

- uses smaller transfer ducts -- piping costs would be approximately onehalf of the indirect system cost

- reduces pumping costs

- does not require freeze protection.

Wet/Dry Cooling

In an effort to take advantage of the good features of a dry cooling system while reducing some of the disadvantages, wet/dry systems are being deve1oped. An example of this type of system is shown in Figure 18 (General Electric Co. 1976). The wet and dry towers do not necessarily have to be separate. Typically, the dry portion of the cooling system will handle more of the load, but when weather conditions are such that the efficiency of the $p l a n t$ is affected, the wet tower will be used to supply additional cooling. This results in low water consumption while keeping the cooling towers at a more economical size than an all dry tower system. Hu (1976) has concluded that wet/dry cooling systems can provide a significant economic advantage over all dry while closely matching the dry tower conservation of water. Table 3 is a result of his study which exemplifies the economics of dry, wet, and wet/dry cooling.

Another method of improving the performance of dry cooling is deluge cooling. This method involves deluging the dry cooling coils with water during adverse weather conditions. The resulting evaporation augments the cooling capability of the dry tower and thus allows smaller size towers. Corrosion and deposition of contaminants are significant problems with deluge cooling. 


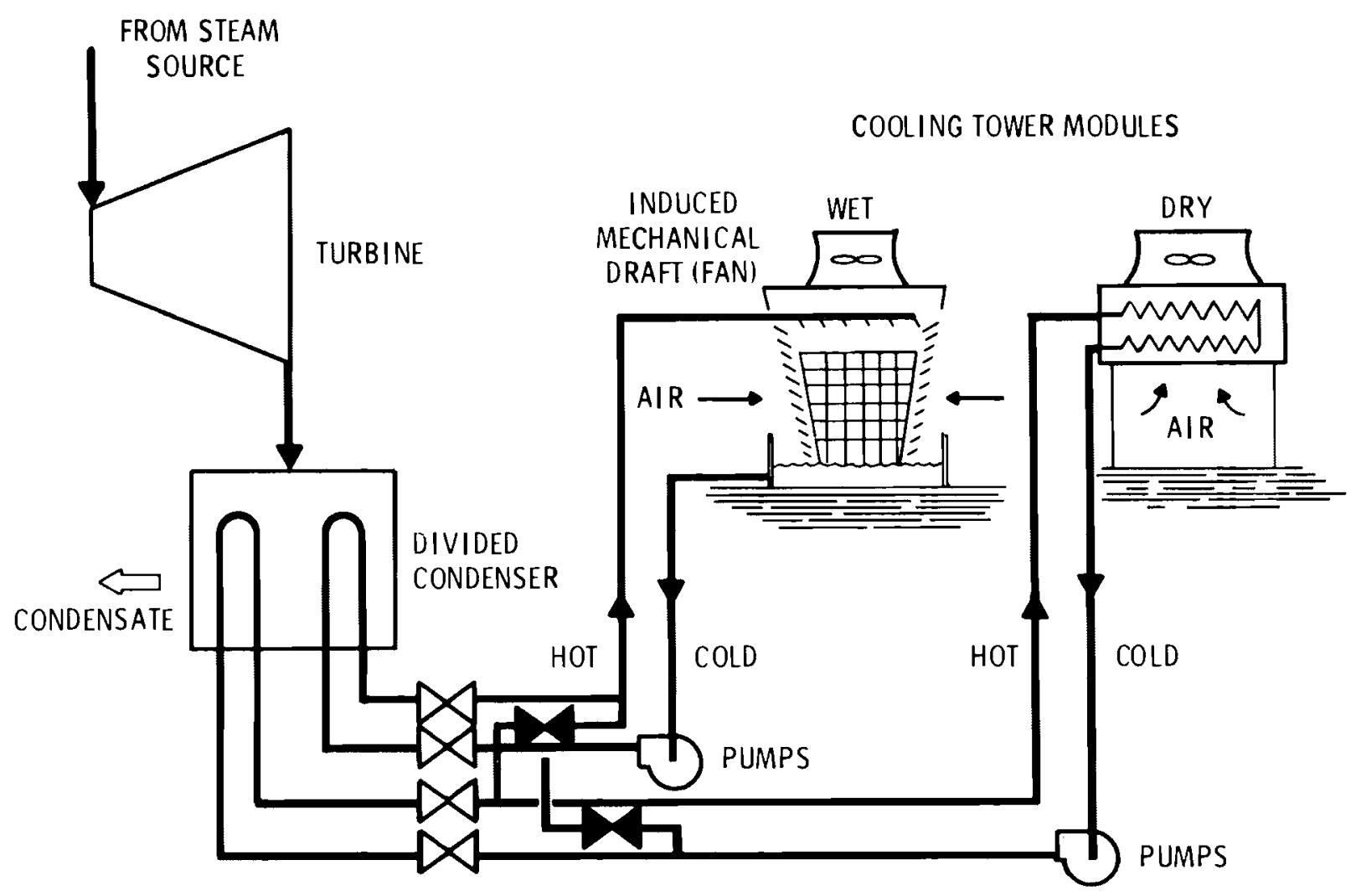

FIGURE 18. Combination Wet/Dry Cooling System Using Separate Cooling Modules

TABLE 3. Major Cost Summary for Optimized Cool ing Tower System (mil/kWhr)

\begin{tabular}{|c|c|c|c|c|c|c|c|c|}
\hline \multirow[t]{2}{*}{ Site: } & Middletown, & Mech. & $\begin{array}{l}\operatorname{Pri} \\
\% \mathrm{M} \\
\mathrm{Me}\end{array}$ & $\begin{array}{l}\text { ing re } \\
\text { ake-up } \\
\text { ch. Se }\end{array}$ & $\begin{array}{l}\text { ear: } \\
\text { Pequi } \\
\text { eries }\end{array}$ & $\begin{array}{l}1985 \\
\text { irement } \\
\text { - Wet } / 0 \\
\end{array}$ & isy - & \multirow{2}{*}{$\begin{array}{l}\text { Mech. } \\
\text { Wet }\end{array}$} \\
\hline & $\operatorname{Dry}(H)(a)$ & Dry $(\mathrm{L})(\mathrm{b})$ & $1 \%$ & $10 \%$ & $20 \%$ & $30 \%$ & $40 \$$ & \\
\hline $\begin{array}{l}\text { Total Capital Cost } \\
\text { (Direct } 8 \text { Indirect } \\
\text { Capital Costs) }\end{array}$ & 2.83 & 5.61 & 3.82 & 3.10 & 2.91 & 2.62 & 2.51 & 1.41 \\
\hline $\begin{array}{l}\text { Total Capac ity Penalty } \\
\text { (Capacity \& Auxiliary } \\
\text { Power) }\end{array}$ & 2.82 & 1.73 & 1.35 & 1.06 & 0.88 & 0.86 & 0.84 & 0.59 \\
\hline $\begin{array}{l}\text { Total Operating Penalty } \\
\text { (Replacement \& Auxiliary } \\
\text { Energies, Make-up Water } \\
\text { \& Maintenance) }\end{array}$ & 2.09 & 1.14 & 0.91 & 0.94 & 0.92 & 0.99 & 0.99 & 0.55 \\
\hline $\begin{array}{l}\text { Total Evaluated } \\
\text { Cost (Sum of Capital \& } \\
\text { Penalty Costs) }\end{array}$ & 7.74 & 3.48 & 6.08 & 5.10 & 4.71 & 4.47 & 4.34 & 2.55 \\
\hline \multicolumn{9}{|c|}{$\begin{array}{l}\text { (a) }=4 \text { Hack Pressure Turbine } \\
\text { (b) L - Conventional Low Back Pressure Turbine }\end{array}$} \\
\hline
\end{tabular}




\section{WATER CONSUMPTION}

All the various cooling options have different water consumption characteristics. If identical atmospheric conditions are assumed, Edmonds et al. (1975) reports the following qualitative ranking (from high to low water consumption):

1. cooling ponds

2. mechanical-draft cooling towers (wet)

3. spray ponds

4. natural draft cooling towers (wet)

5. wet/dry cooling towers

6. once-through cooling.

Dry cooling water consumption is essentially zero (minor consumption could be attributed to tube leakage). Table 4 (General Electric Co., 1976) demonstrates the difference in plant water consumption for various cooling methods. The values quoted include inplant usage as well as evaporation and drift losses. These results are generally consistent and demonstrate that cooling ponds consume the most water, while dry cooling is the best solution from a water consumption standpoint.

TABLE 4. Typical Water Consumption Data for Alternative Cooling Modes

\begin{tabular}{|c|c|c|}
\hline \multirow[b]{2}{*}{ Cooling Mode } & \multicolumn{2}{|c|}{$\begin{array}{l}\text { Approximate Annual } \\
\text { gal/hr/gross kWe }\end{array}$} \\
\hline & Fossin(a) & Nuclear (LWR) (b) \\
\hline $\begin{array}{l}\text { Once-through } \\
\text { Spray pond } \\
1 \text { acre/MW pond } \\
2 \text { acre/MW pond } \\
\text { Mechanical draft wet towers } \\
\text { Natural draft wet tower } \\
\text { Dry tower (in-plant) } \\
\text { Peak shaved dry/wet system }\end{array}$ & $\begin{array}{l}0.30 \\
0.40 \\
0.50 \\
0.68 \\
0.43 \\
0.38 \\
0.022(c) \\
0.02-0.05\end{array}$ & $\begin{array}{l}0.45 \\
0.60 \\
0.75 \\
1.0 \\
0.65 \\
0.57 \\
0.015 \\
0.02-0.07\end{array}$ \\
\hline
\end{tabular}

(a) Fossil - 40\% gross efficiency with $15 \%$ heat loss up the stack

(b) Nuclear - 33\% gross efficiency

(c) Includes ash sluicing 


\section{ENERGY AND RELATED WASTE HEAT GENERATION}

The framework in which dry cooling will play an important role can best be described by analyzing the projections of energy development. None of the processes utilized to produce or convert energy are $100 \%$ efficient. Consequently, significant quantities of energy are lost as waste heat. Based on the Nation's increasing need for energy and the fact that water availability problems are becoming apparent in certain areas of the United States, it soon becomes evident that dry cooling will play an important role. The actual magnitude of the future role of dry cooling cannot be precisely assessed; however, by looking at projections for energy development and the associated waste heat generation, the probable role of dry cooling can be estimated.

\section{ENERGY PROJECTIONS}

A variety of energy projections are presented in this section. Since forecasts are somewhat imprecise by nature, none of the projections agree entirely with one another.

The energy projections obtained from the HI study (Candela et al., 1975 and 1977) are based on six scenarios that attempt to bracket the range of plausible possibilities. Only the following four primary scenarios will be discussed: low growth/low coal; intermediate growth/populist; intermediate growth/establishment; and high growth/high coal. The results of the four scenarios are presented in Table 5. The values listed for 1972 are the initial conditions used at the start of each scenario. The following discussion serves to briefly indicate the character of each scenario; for a more detailed discussion, the reader is referred to the source report.

The low growth/low coal scenario is characterized as a pessimistic assessment. The low growth rates indicated may occur as a result of short, unusually deep, and closely spaced recessions rather then a severe depression. The utilization of coal is assumed to follow a slow growth pattern. This results in high import rates of $0 i 1$ and natural gas and associated high energy costs. 


\section{TABLE 5. Scenarios of Energy Consumption - Btu $\times 10^{15}$}

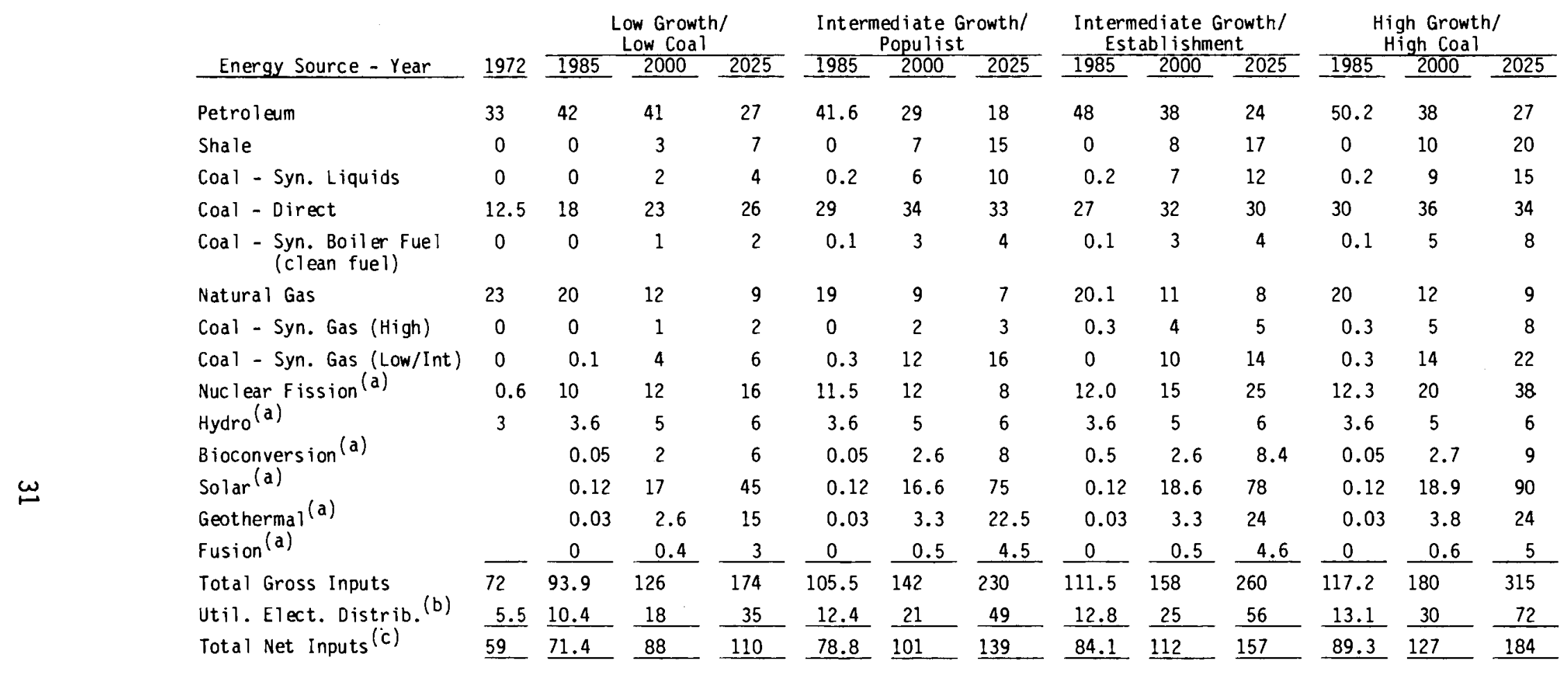

(a) These values represent raw energy consumed based on a conversion efficiency of $10,000 \mathrm{Btu} / \mathrm{kWh}$ (this is an equivalent conversion efficiency of $34 \%$.

(b) Indicates amount of electricity generated.

(c) These values are equal to the total gross inputs minus the energy consumed for electricity generation plus the anount of electricity generated plus any power plant waste heat utilization. 
The two intermediate growth scenarios are quite similar, except there is a distinction made as to whether industry and government decisions will determine energy policy or if popular opinion will be the overriding influence. The intermediate growth scenarios are based on recent growth trends. The study indicates that the scenario most likely to occur is the intermediate growth/ establishment scenario. This scenario assumes that the establishment (i.e., the major decision makers in industry and government) will have the most significant effect on policy decisions that determine energy use and production patterns. The intermediate growth/populist scenario, on the other hand, is a projection of what would occur if popular opinion had more influence.

The high growth/high coal scenario portrays the effects of success in developing alternative energy sources and there is a resultant high growth in energy use. Coal is extensively used in this scenario as a primary energy source and as a raw material for synthetic fuels. The high use of coal indicates success in dealing with environmental problems associated with coal use.

The study indicates that the four scenarios should bracket the potential future growth in U.S. energy supply and demand. The intermediate growth/ establishment scenario should predict what is most likely to occur. It is noted that none of the individual scenarios can be expected to portray the trends that might occur for the entire time span to year 2025. Changing public opinion, external influences such as OPEC, technological break-throughs, and unforeseen "surprises" will cause the actual trends to exhibit characteristics of some or all of the scenarios. This means that the actual future growth should be bracketed by the trends resulting from each scenario. Since each scenario is considered to hold true over the entire time span, the predictions should portray a range of values that include what will actually occur.

Before heavy reliance can be placed on the values presented in Table 5 , these values must be compared with results of other projections. Table 6 is based on data reported in a U.S. Department of Commerce study (1975) and has 
been adapted to include a more recent Department of Energy (DOE) study (DOE 1979) and the ranges of the Hudson Institute scenarios. This table summarizes energy supply estimates for 1985 from seven other studies. The values used by the HI study are within the range of values predicted by the other studies, except for coal. The HI study predicts a somewhat larger supply of coal. The total supply values are quite close to the total supply predicted by the other studies. This indicates that the HI study projects a somewhat higher emphasis on coal use.

Tables 7 and 8 present similar information for the years 2000 and 2020 to 2025, respectively. These tables are based on information in the 1978 Annual Report to Congress (prepared by DOE) and have been compared to the HI study. Caution should be exercised when analyzing these projections since they are primary energy supply estimates and as such do not consider supply of synthetic fuels. Consequently, the coal supply values include coal that would be used for synthetic fuel production. Information was contained in the study that allowed the values for synthetic fuels and shale oil production to be tabulated for the Energy Information Administration (EIA) projection (it was necessary to assume a conversion efficiency of $80 \%$ for the low Btu synthetic gas production).

In the year 2000 some differences are apparent. The HI study indicates a somewhat higher emphasis on synthetic fuel production, but most significantly the other fuels category is projected to supply a much higher amount of energy. If the contribution from hydropower is included, the HI study may be predicting three to five times higher availability of energy from these sources (compare high value with high and low value with low). The total supply values are bracketed by the HI study, however. The low growth scenario appears to more closely match the other studies.

In the years 2020 to 2025 the same trends are apparent. The HI study predicts from four to ten times higher contribution from other technologies (including hydropower). This indicates that the emphasis in the HI study is on heavier utilization of renewable resources. 


\section{TABLE 6. Comparisons of 1985 Supply Estimates ( $10^{15}$ Btu)}

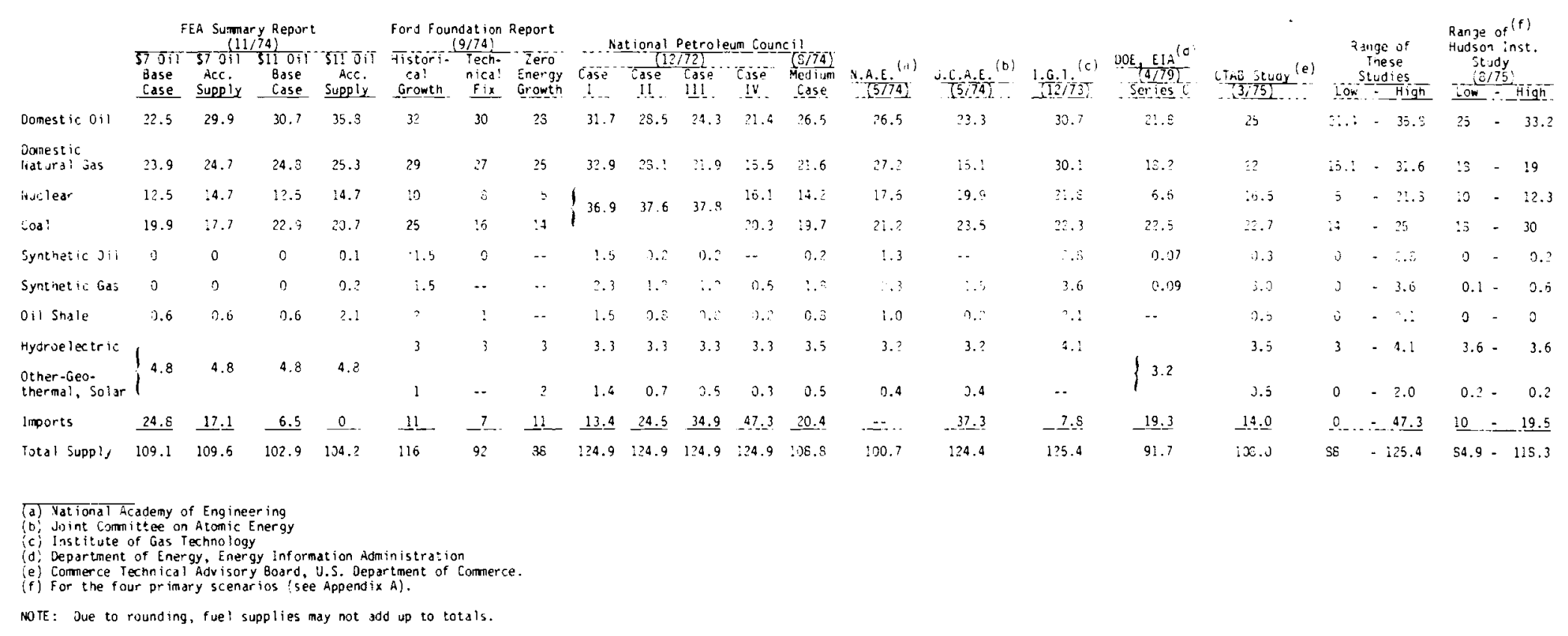




\section{TABLE 7. Comparison of 2000 Supply Estimates ( $\left.10^{15} \mathrm{Btu}\right)$}

\begin{tabular}{|c|c|c|c|c|c|c|}
\hline & $\begin{array}{c}\text { EIA(a) } \\
(1978) \\
\text { Series C } \\
\end{array}$ & BNL/DJA(a) & $\begin{array}{l}\operatorname{ETA}-(a) \\
\text { MACRO }\end{array}$ & FOSSIL2(a) & LEAP (a) & $\begin{array}{l}\text { Range of (b) } \\
\text { H.I. Study } \\
(8 / 75) \\
\text { Low - High } \\
\end{array}$ \\
\hline Domestic 0 il & 23.1 & 20.2 & 32.9 & 21 & 24.9 & 20 to 23 \\
\hline $\begin{array}{l}\text { Domestic } \\
\text { Natural Gas }\end{array}$ & 19.3 & 18.3 & (c) & 18 & 19.3 & 8 to 10 \\
\hline Nucl ear & 16.9 & 11.7 & 12.5 & 16 & 16.9 & 12 to 20 \\
\hline Coal 1 & 37.6 & 44.6 & 43.1 & 38 & 46.9 & 24 to 41 \\
\hline Synthetic 0 il & 2.6 & (d) & (d) & (d) & (d) & 2 to 9 \\
\hline Synthetic Gas & 4.5 & (d) & (d) & (d) & (d) & 12 to 19 \\
\hline Shale 0 il & 1.8 & (e) & (e) & (e) & (e) & 3 to 10 \\
\hline Hydroelectric & & & & & & 5 to 5 \\
\hline $\begin{array}{l}\text { Other - Geothermal } \\
\text { solar }\end{array}$ & 5.0 & 10.4 & 9.0 & 10 & 5.1 & 22 to 26 \\
\hline Imports & 12.0 & 12 & 25.6 & 20 & 12.0 & 10 to 23 \\
\hline Total Supply & 122.8 & 117.2 & 123.1 & 122 & 125.1 & 117 to 181 \\
\hline
\end{tabular}

(a) Based on information Reference DOE, I978

(b) For the four primary scenarios (see Appendix A)

(c) Included under oil

(d) These are primary energy projections, therefore synthetic fuels were not tabulated

(e) Not tabulated, probably included under domestic oil.

TABLE 8. Comparison of 2020 to 2025 Supply Estimates ( $10^{15}$ Btu)

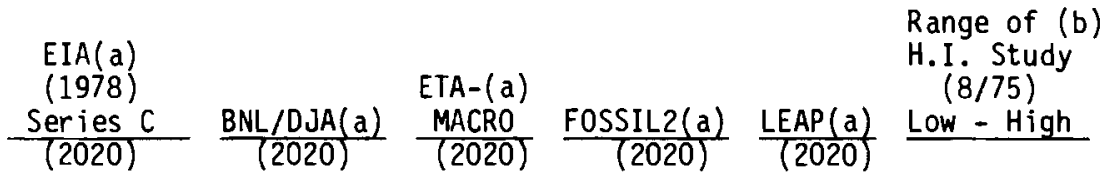

\begin{tabular}{|c|c|c|c|c|c|c|}
\hline Domestic $0 i 1$ & 15.2 & 19.5 & 18.1 & 10 & 20.3 & 12 to 14 \\
\hline Domestic Natural Gas & 11.4 & 17.7 & (c) & 10 & 11.4 & 6 to 7 \\
\hline Nuc lear & 43.6 & 18.5 & 39.9 & 24 & 43.6 & 8 to 38 \\
\hline Coal 1 & 47.2 & 75.1 & 86.7 & 74 & 78 & 28 to 42 \\
\hline Synthetic 0 il 1 & 11.0 & (d) & (d) & (d) & (d) & 4 to 15 \\
\hline Synthetic Gas & 11.8 & (d) & (d) & (d) & (d) & 8 to 30 \\
\hline $\begin{array}{l}\text { Sha le } 0 i 1 \\
\text { Hydroe lectric }\end{array}$ & $i^{5.1}$ & (e) & (e) & (e) & (e) & $\begin{array}{l}7 \text { to } 20 \\
6 \text { to } 6\end{array}$ \\
\hline $\begin{array}{l}\text { Other - Geothermal, } \\
\text { sol ar }\end{array}$ & 7.4 & 18.5 & 37. & 21 & 8.0 & 69 to 128 \\
\hline Imports & 8.3 & $\underline{5.0}$ & $\underline{12.8}$ & $\underline{29}$ & $\underline{8.3}$ & 7 to 8 \\
\hline Total Supply & 161 & 154.3 & 194.5 & 167 & 169.7 & 155 \\
\hline
\end{tabular}

(a) Based on information Reference DOE, 1978

(b) For the four primary scenarios (see Appendix A)

(c) Inc luded under oil

(d) These are primary energy projections, therefore synthetic fuels were not tabulated

(e) Not tabulated, probably included under domestic oil. 
For discussion purposes in the subsequent section on waste heat generation it will be assumed that the HI study may over-emphasizes solar and geothermal by a factor of 5 in the year 2000 and by a factor of 10 in the year 2025 .

Other sources have projected values for energy supply from alternative energy sources. Many of these projections have been summarized in Table 9. Energy projection values that are found in the literature are not presented on a consistent basis. Some authors present energy values on a fuel displaced basis. This method is used for solar, geothermal, and hydropower so that an estimate of fuel displaced due to use of these technologies can be assessed. Typically, the output energy of the technology is converted to an equivalent energy input as if the plant were a conventional power plant. Normally, a value of around $10,000 \mathrm{Btu} / \mathrm{kWh}$ is used to perform this conversion. This is equivalent to assuming the plant has a thermal efficiency of $34 \%$. Other authors present values on the installed electrical capacity of future power plants. This is not necessarily a good value to use for comparison since the capacity factor (the average output of a plant divided by its design output) is not the same for various technologies. Still other authors will present values on actual electricity generated. Therefore, certain assumptions were required so that Table 9 could be presented in a consistent manner to ease later comparisons. The assumptions that have been used throughout this report to perform the required conversions are listed in Appendix B. The values for solar and geothermal cannot be directly compared with the previous tables since Table 9 only considers solar and geothermal electricity generated and in the case of solar, it only indicates values for electricity generated by central tower power plants. Residential heating and industrial process heat has been excluded.

To facilitate comparison, Table 10, based on the HI study, has been constructed. This table includes values for the energy content of synthetic fuels expected to be produced as we 11 as the amount of electrical energy expected to be generated due to solar central tower plants and geothermal power plants. The synthetic fuel values are taken directly from Table 5, while the solar and geothermal values are developed in the next section and are presented here 
TABLE 9. Projections of Energy Supply from Alternative Energy Technologies, Quadritiion Btu

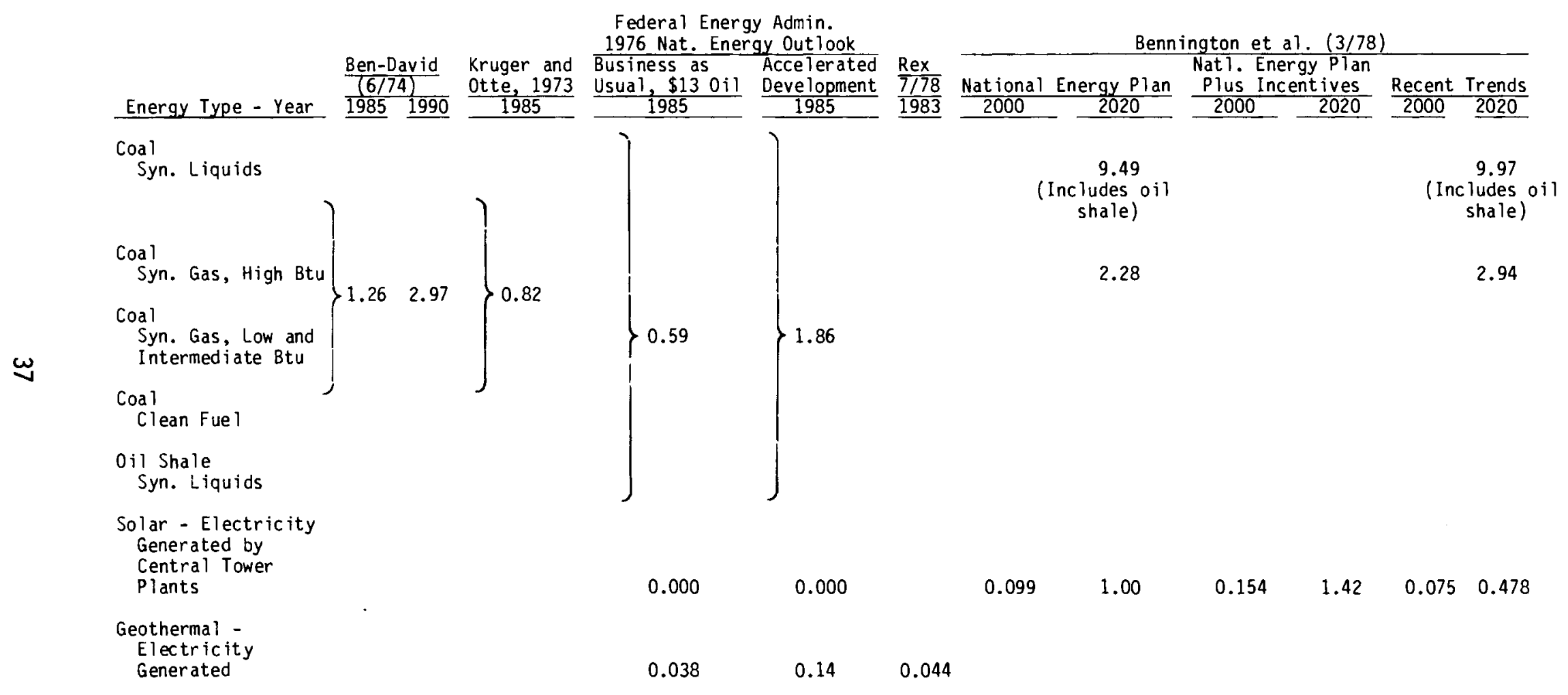


TABLE 9. (contd)

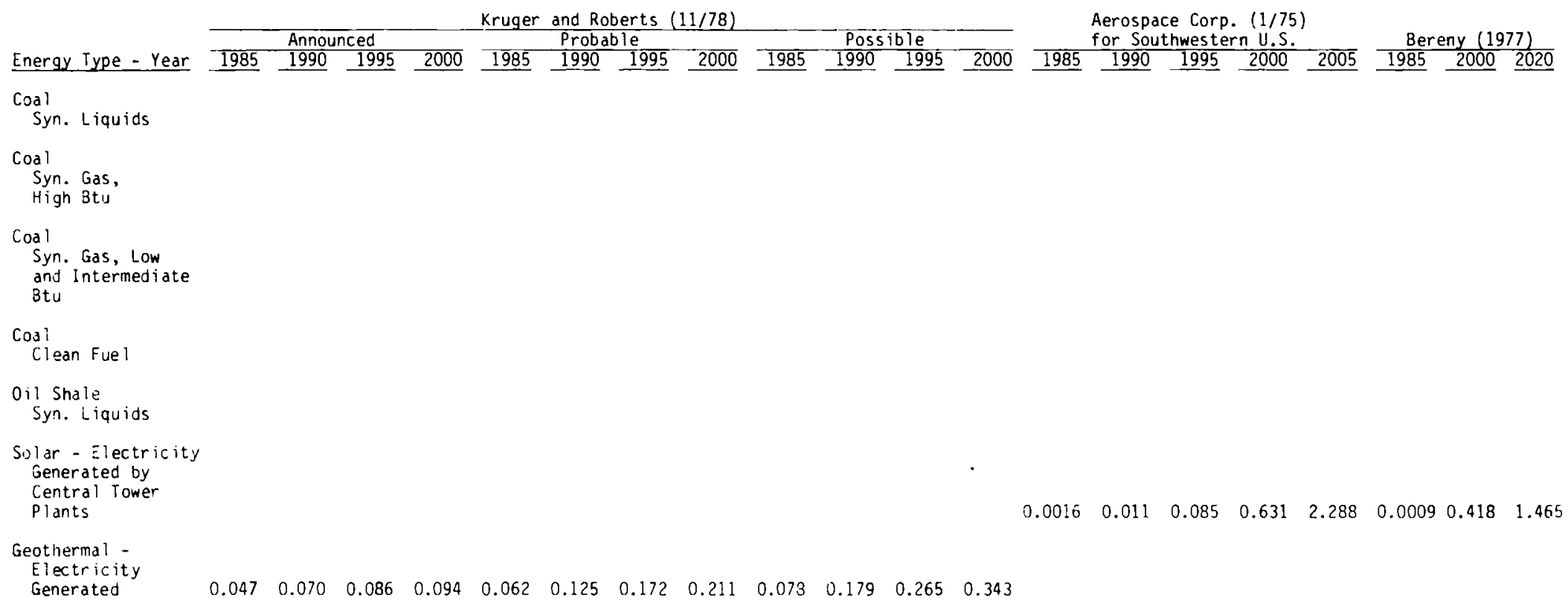




\section{TABLE 10. Projections of Energy Supply from Alternative Energy Technologies, Based on Hudson Institute Study, Quadrillion Btu}

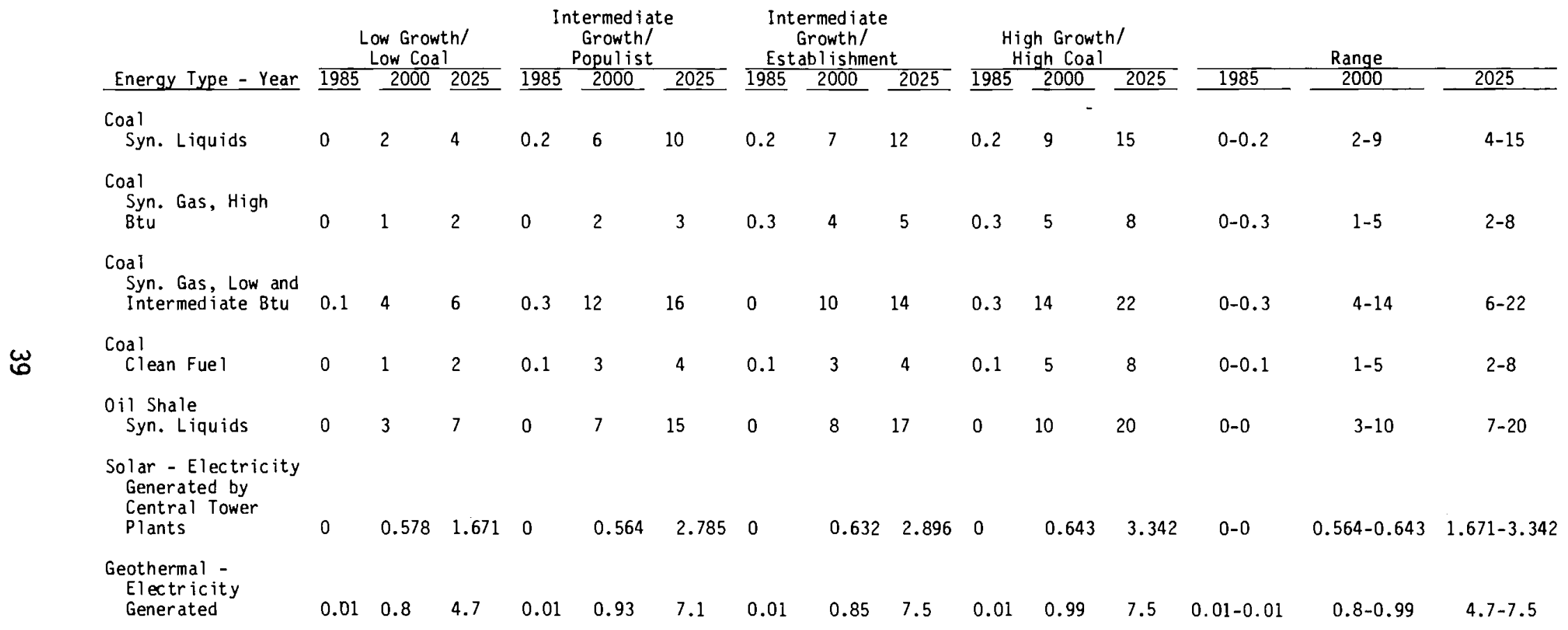


solely for convenience. These values can be compared directly with the other energy projections listed in Table 9. A value-by-value comparison of these projections with the ranges given in the HI study indicates some general differences in the way various researchers have viewed the development of alternative energy sources. The HI values are generally consistent with the synthetic liquid and coal gasification values derived by Bennington et al. (1978) and the Federal Energy Administration business as usual (BAU) in the near and far-term projection. The studies by Ben-David et a1. (1974) and Kruger and Otte (1973) indicate higher production of synthetic gas in 1985 than the HI study. In the 1985 time frame the HI study agrees with many of the solar projections; however, Bennington et al. and the FEA (BAU) predict lower solar generation. In the 2000 and 2020 to 2025 time frame the HI study predicts much higher values for solar energy. The HI geothermal predictions are similar. For 1985 the HI study predicts a lower contribution from geothermal; however, by the years 2000 to 2025 the HI study predicts a much higher contribution from geothermal.

Large discrepancies in projections far in the future are to be expected. Relatively small changes in assumed growth rates can have major effects after a long time span. It would be difficult to determine which projections are more correct; all projections should be viewed as qualitative and only indicative of what could occur. The HI study has been used as a basis for cooling requirement calculations. It should be noted that the $H I$ study does portray a future with much heavier reliance on geothermal and solar than other authors. This could be a valid assumption, especially in light of the 1973 Arab oil embargo and the recent trends in OPEC oil prices.

Significantly, a recent report (Griffin 1979) states that the Nation's energy plan has as its goal the supply of $20 \%$ of the U.S. energy needs from solar resources by the year 2000. Another study by a panel of solar experts concluded that by the year 2020 the sun could provide $20 \%$ of the total energy demand (Backus and Brown 1976); while an ERDA (now DOE) study indicates that $25 \%$ of the Nation's energy needs can be met by solar by the year 2020 (Bereny 1977). Referring to Table 5, the HI study projects only $11 \%$ to $13 \%$ of the Total Gross Energy Input will be supplied by solar in the year 2000. The solar contribution is projected to be from $26 \%$ to $33 \%$ in the year 2025 . 
By comparing highest projection with highest projection, and lowest with lowest, it appears that the HI study projects 2 to 3.5 times higher solar central tower contribution in the year 2025 time frame. (The actual value would be somewhat lower since the other studies only project out to the year 2020.) In the year 2000 the HI study projects 1 to 7.5 times higher solar use and a 3 to 8.5 times higher geothermal use.

\section{WASTE HEAT GENERATION}

Any energy conversion plant, whether it converts energy into electricity or into another form (i.e., gas from coal) can be modeled from an energy balance standpoint by Figure 19. $E_{i n}$ is the raw energy that is brought into the plant, while $E_{\text {out }}$ is the useful energy taken out of this plant. $Q_{D}$ represents the heat energy lost directly to the environment. These losses are due to stack losses from combustion of fuels and convective and radiative heat lost from piping and vessels. $Q_{I}$ is the energy that must be dissipated to the environment through a heat exchange device. $Q_{I}$ and $Q_{D}$ combined constitute the total heat energy lost, $Q$. In electric generating $p l a n t s ~ Q$ is much larger than the actual amount of electricity generated.

A plant conversion or thermal efficiency can be defined as follows:

$$
n=\frac{E_{\text {out }}}{E_{\text {in }}}
$$

Since the plant is assumed to be operating in a steady-state condition, i.e., no energy storage within the plant, the following equation can be written based on conservation of energy considerations:

$$
E_{\text {in }}=Q+E_{\text {out }}
$$




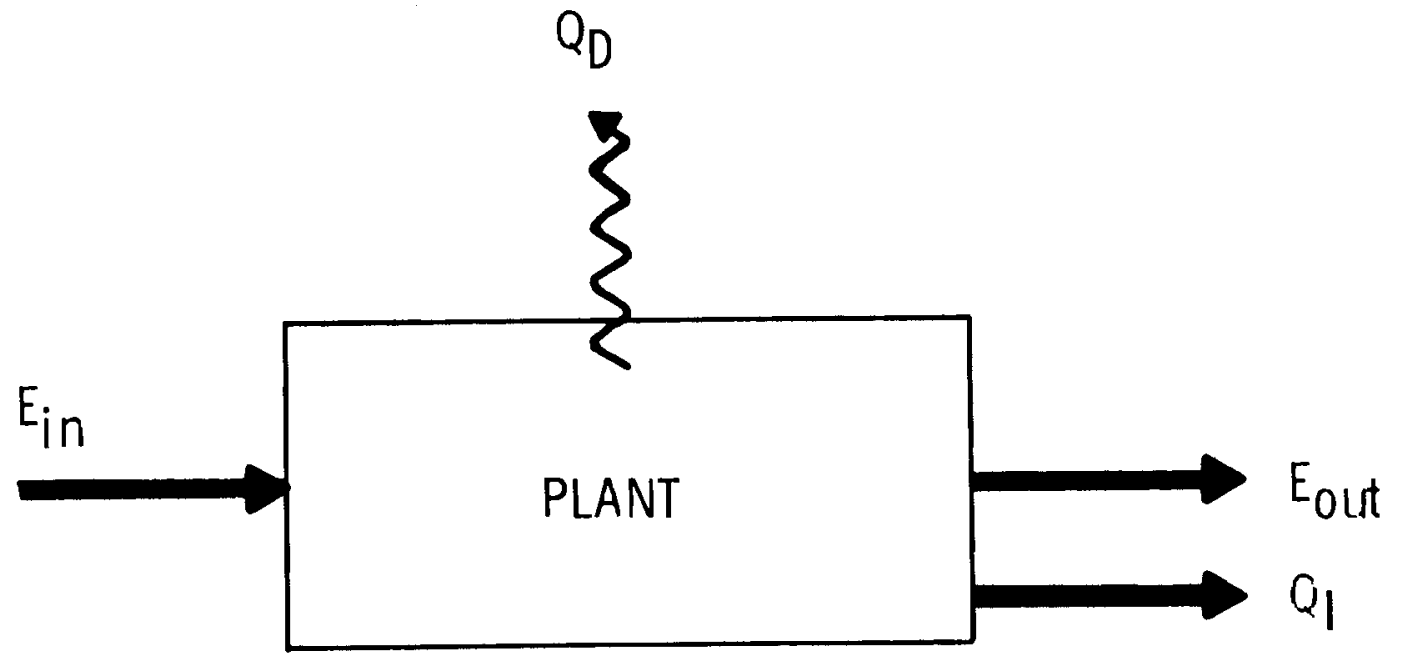

FIGURE 19. Energy Balance of an Energy Conversion Process

A third equation can be derived by combining Equations (1) and (2) that gives $Q$ as a function of $n$ and $E_{\text {out }}$. The result is:

$$
Q=E_{\text {out }}(1 / n-1)
$$

If the amount of energy produced and the plant efficiency is known the amount of heat lost can be calculated.

With further information quantifying the fraction of $Q$ that is lost directly, values for $Q_{I}$ and $Q_{D}$ can be obtained, namely:

$$
\begin{aligned}
& Q_{D}=F \times Q \\
& Q_{I}=Q-F \times Q
\end{aligned}
$$

where

$$
F=\text { fraction of waste heat lost directly. }
$$

Values for $n$ and $F$ have been obtained from the literature (Probstein and Gold 1978; University of OKlahoma 1975; Ermak 1978 and 1971) and are listed in 
Table 11 for the alternative energy sources as well as for conventional power plants. The median values have been used for all subsequent calculations.

Calculations of the amounts of waste heat generated have been based on the appropriate values from Table 5. The values for solar and geothermal have been converted to actual electrical energy generated based on the distribution indicated in Tables 12 through 14. Only the contribution to solar electric from central tower power plants has been considered since they are the only plants that are likely to require cooling towers. The resultant energy produced as well as the associated heat lost to the environment and through a cooling device have been summarized for the four scenarios in Tables 15 through 18. For comparison, the values for fossil fuel and nuclear power plants have been included. (These values are based on the appropriate conversion efficiencies and the distributions indicated in Appendix A.) When reviewing these values, it should be kept in mind that the HI study may be projecting an energy impact from solar and geothermal that is around a factor of 5 higher in the year 2000 and a factor of 10 higher in the year 2025. To reflect this possibility the calculations in parenthesis in Tables 15 through 18 have been listed. These calculations were performed with the assumption that the solar and geothermal values may be high by a factor of 5 and 10 in the years 2000 and 2025 , respectively. The electrical energy that would have been generated by these technologies was redistributed in equal share to the nuclear and conventional fueled power $\mathrm{plants.}$

The heat loss values for the synthetic fuel technologies have been based on an energy output due solely to the product synthetic fuels produced. In actuality, this is not quite correct since there are by-products associated with synthetic fuel production. Heat balances performed by Probstein and Gold indicate that the by-products may constitute an additional $7 \%$ energy output based on the product produced for synthetic 1iquids; $0 \%$ to $13 \%$ for synthetic gas; up to $37 \%$ for clean fue 1 ; and $10 \%$ to $20 \%$ for oil shale. This means that if the by-products are considered, the actual waste heat generated as shown in Tables 15 through 18 should be increased by the appropriate percentage. These additions have not been indicated since the qualitative nature of energy projection and the approximate nature of the assumptions used do not warrant this kind of detail. 
TABLE 11. Values for $n$ and $F$

\begin{tabular}{|c|c|c|}
\hline Technology & $\begin{array}{c}\text { Plant Conversion } \\
\text { or Thermal Efficiency, } \\
n\end{array}$ & $\begin{array}{l}\text { Fraction of } \\
\text { Unrecovered Heat } \\
\text { Lost Directly, F }\end{array}$ \\
\hline $\begin{array}{l}\text { Coal } \\
\text { Syn. Liquids }\end{array}$ & 0.70 to $0.75(72.5)$ & 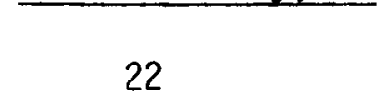 \\
\hline $\begin{array}{l}\text { Coal } \\
\text { Syn. Gas, High Btu }\end{array}$ & 65 to $70(67.5)$ & 28 to $41(34.5)$ \\
\hline $\begin{array}{l}\text { Coal } \\
\text { Syn. Gas, Low and } \\
\text { Intermediate Btu }\end{array}$ & 65 to $95(80)$ & $30(a)$ \\
\hline $\begin{array}{l}\text { Coal } \\
\text { Clean Fue } 1\end{array}$ & 75 to $80(77.5)$ & 37 \\
\hline $\begin{array}{l}\text { 0il Shale } \\
\text { Syn. Liquids }\end{array}$ & 57 to $72(64.5)$ & $30(a)$ \\
\hline $\begin{array}{l}\text { Solar Electric } \\
\text { Central Tower }\end{array}$ & 30 to $40(35)(c)$ & $5(b)$ \\
\hline Geothermal & 8 to $18(13)$ & $5(b)$ \\
\hline $\begin{array}{l}\text { Fossil Fueled } \\
\text { Power Plant }\end{array}$ & 38 to 40 (39) & 15 \\
\hline $\begin{array}{l}\text { Nuclear Fueled } \\
\text { Power Plant }\end{array}$ & 32 to $33(32.5)$ & 5 \\
\hline
\end{tabular}

\footnotetext{
( ) indicates the median value

(a) Value is median of range given by Probstein and Gold for Synfue? production (20 to $40 \%$ )

(b) $5 \%$ assumed. Assumption based on analogy with a nuclear plant, i.e., no stack losses from combustion of fuel as in a fossil fueled plant.

(c) $35 \%$ has been used since the Mitre study indicates that central tower electric generation will be the primary method.
} 
TABLE 12. Percentage of Geothermal Energy Consumption Utilized by Electric Utilities (a)

\begin{tabular}{lcccc}
\multicolumn{1}{c}{ Scenario Name } & & \multicolumn{3}{c}{ Year } \\
$\begin{array}{l}\text { Low Growth/ } \\
\text { Low Coal }\end{array}$ & $\frac{2000}{100}$ & $\frac{2025}{91}$ & $\frac{}{91}$ \\
$\begin{array}{l}\text { Intermediate Growth/ } \\
\text { Populist }\end{array}$ & 100 & 83 & 93 \\
$\begin{array}{l}\text { Intermediate Growth/ } \\
\text { Establishment }\end{array}$ & 100 & 76 & 91 \\
$\begin{array}{l}\text { High Growth/ } \\
\text { High Coal }\end{array}$ & 100 & 77 & 91
\end{tabular}

(a) Based on "sector consumption of energy fuels" reported in the HI Study, (see Appendix A).

TABLE 13. Percentage of Solar Energy Consumption(a) Utilized by Electric Utilities

\begin{tabular}{|c|c|c|c|}
\hline \multirow[b]{2}{*}{ Reference } & \multicolumn{3}{|c|}{ Year } \\
\hline & 1985 & 2000 & 2025 \\
\hline Mitre Study & 0 & 36 & 40 to 43 \\
\hline Bereny & 26 & 63 & 43 \\
\hline Median & 13 & 50 & 42 \\
\hline
\end{tabular}

(a) Excluding Bioconversion 
TABLE 14. Percentage of Solar Electric Generation Due to Selected Technologies

\begin{tabular}{|c|c|c|c|c|c|c|}
\hline \multirow{3}{*}{ Technology } & \multicolumn{6}{|c|}{ Year } \\
\hline & 1985 & & 2000 & & $2020(0)$ & \\
\hline & $\begin{array}{c}\text { Fuel D isplaced } \\
\text { quads/year }\end{array}$ & $\%$ of Total & $\begin{array}{l}\text { Fuel Displaced } \\
\text { guads/year }\end{array}$ & q of Total & $\begin{array}{l}\text { Fuel Displaced } \\
\text { guads/year }\end{array}$ & \% of Total \\
\hline Solar Thermal & $-(0.003)$ & $\begin{array}{l}0(a)(4) \\
\text { median }=2\end{array}$ & $0.3(1.31)$ & $\begin{array}{l}15(25) \\
\text { median }=20\end{array}$ & $(4.58)$ & $\begin{array}{l}24(28) \\
\text { median }=26\end{array}$ \\
\hline Ocean Therma1 & $-(0.006)$ & $0(8)$ & $-(0.65)$ & $0(12)$ & $2.4(2.62)$ & $20(16)$ \\
\hline Photovoltaics & $-(0.006)$ & $0(8)$ & $-(1.96)$ & $0(37)$ & $0.2(5.23)$ & $2(32)$ \\
\hline Wind Energy & $-(0.056)$ & $100(79)$ & $1.7(1.31)$ & $85(25)$ & $6.6(3.92)$ & $55(24)$ \\
\hline Total & $(0.071)$ & & $2.0(5.23)$ & & $12.1(16.4)$ & \\
\hline
\end{tabular}

- Less than 0.01 quad/year

(a) The Mitre study projects that only the wind energy systems will be commercial by 1985 .

(b) These values for year 2020 were used to distribute the electricity generated in year 2025

( ) Indicates values based on the study by Bereny, 1977. The other values are from the Mitre study, 1978.

The values presented in Tables 15 through 18 are better understood if the distribution of cooling requirements for alternative energy sources and conventional power sources are compared with each other. Tables 19 through 22 have been developed for that purpose and serve to summarize the cooling requirements through the year 2025. In addition to the values based on the HI study, the values in parentheses indicate the cooling distribution if the contribution from solar and geothermal sources is taken to be a factor of 5 less in the year 2000 and a factor of 10 less in the year 2025. The energy that would have been produced by solar and geothermal sources was distributed equally to nuclear and fossil fueled plants.

In sumary, it appears that the actual cooling needs for alternative energy sources will be quite small in 1985 on the order of $1 \%$ to $2 \%$ of the total cooling requirements. In the year 2000 alternative energy sources could require between $33 \%$ and $40 \%$, and by the year 2025 the range could be $59 \%$ to $76 \%$ of the total. If the contribution from solar and geothermal is less by a factor of 5 in the year 2000 and by a factor of 10 in the year 2025, the 
TABLE 15. Summary of Energy and Waste Heat Generation Low Growth/Low Coal Scenario, Quadrillion Btu

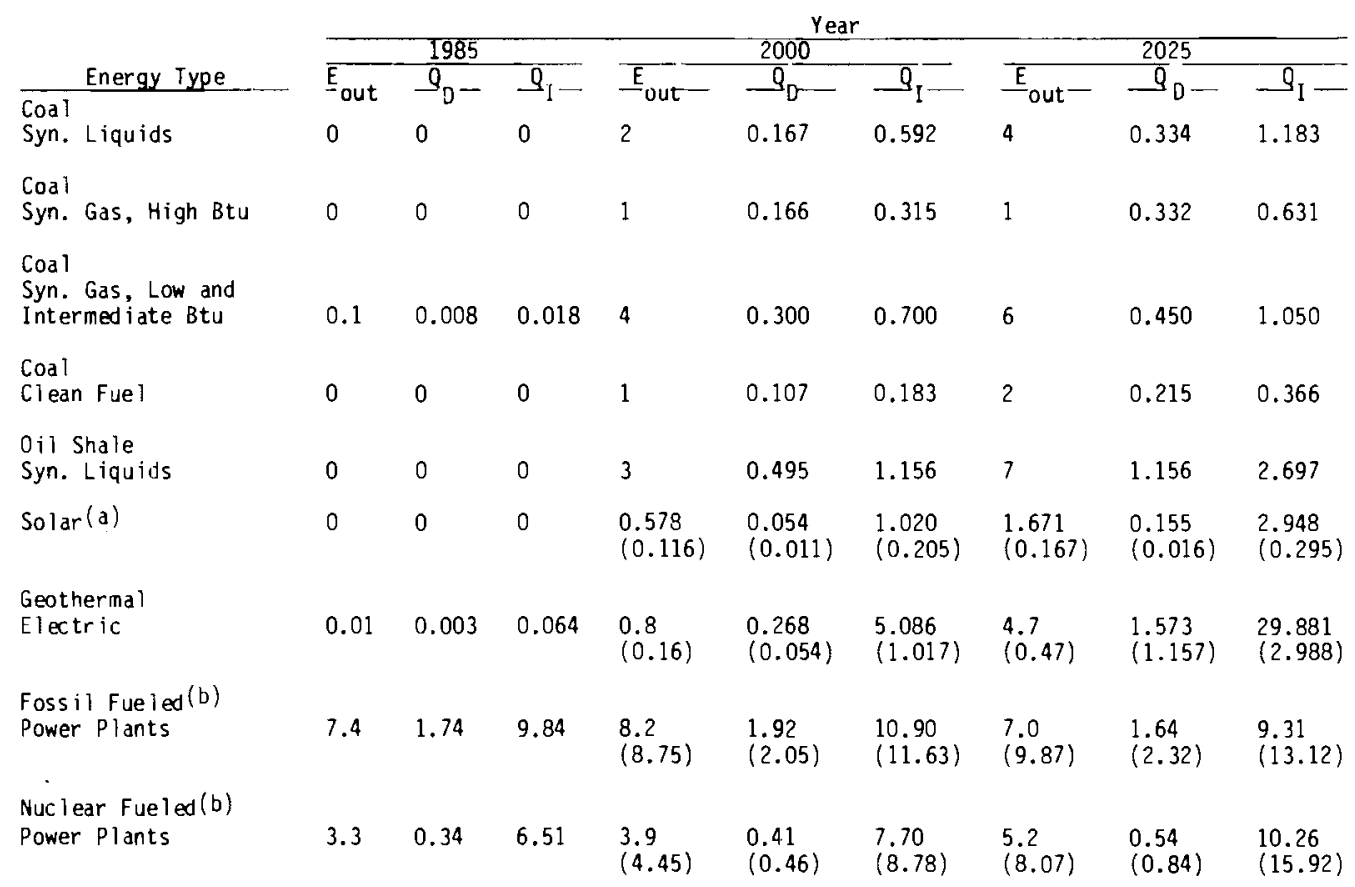

(a) Contribution from central tower power plants only. Based on percentages in Tables 13 and 14

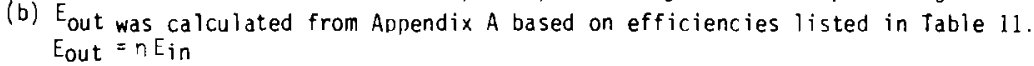

percentages would be: $17 \%$ to $27 \%$ in the year 2000 and $24 \%$ to $34 \%$ by the year 2025. The values indicate that a significant portion of the cooling needs by the year 2000 could be due to the alternative energy technologies and an even higher share of the total cooling requirement will be needed by the year 2025 . 
TABLE 16. Summary of Energy and Waste Heat Generation Intermed iate Growth/Populist Scenario, Quadrillion Btu

\begin{tabular}{|c|c|c|c|c|c|c|c|c|c|}
\hline \multirow{3}{*}{ Energy Type } & \multicolumn{9}{|c|}{ Year } \\
\hline & \multicolumn{3}{|c|}{1985} & \multicolumn{3}{|c|}{2000} & \multicolumn{3}{|c|}{2025} \\
\hline & $\bar{E}_{\text {out }}$ & $\theta_{0-}$ & $Q_{1-}$ & $E_{\text {out - }}$ & $\underline{q}_{0}$ & $\overline{9}_{\mathrm{I}}-$ & $\bar{E}_{\text {out- }}$ & $\mathbf{Q}_{\mathrm{D}}$ & $\mathrm{Q}_{\mathrm{I}}$ \\
\hline $\begin{array}{l}\text { Coal } \\
\text { Syn. Liquids }\end{array}$ & 0.2 & 0.017 & 0.059 & 6 & 0.501 & 1.775 & 10 & 0.834 & 2.959 \\
\hline $\begin{array}{l}\text { Coal } \\
\text { Syn. Gas, High Btu }\end{array}$ & 0 & 0 & 0 & 2 & 0.332 & 0.631 & 3 & 0.498 & 0.946 \\
\hline $\begin{array}{l}\text { Coal } \\
\text { Syn. Gas, Low and } \\
\text { Intermed iate Btu }\end{array}$ & 0.3 & 0.023 & 0.053 & 12 & 0.900 & 2.100 & 16 & 1.200 & 2.800 \\
\hline $\begin{array}{l}\text { Coal } \\
\text { Clean Fuel }\end{array}$ & 0.1 & 0.011 & 0.018 & 3 & 0.322 & 0.549 & 4 & 0.430 & 0.732 \\
\hline $\begin{array}{l}\text { Oil Shale } \\
\text { Syn. Liquids }\end{array}$ & 0 & 0 & 0 & 7 & 1.156 & 2.697 & 15 & 2.477 & 5.779 \\
\hline Solar(a) & 0 & 0 & 0 & $\begin{array}{l}0.546 \\
(0.113)\end{array}$ & $\begin{array}{l}0.052 \\
(0.010)\end{array}$ & $\begin{array}{l}0.995 \\
(0.199)\end{array}$ & $\begin{array}{l}2.785 \\
(0.279)\end{array}$ & $\begin{array}{l}0.259 \\
(0.026)\end{array}$ & $\begin{array}{l}4.914 \\
(0.491)\end{array}$ \\
\hline Geothermal & 0.01 & 0.003 & 0.064 & $\begin{array}{l}0.93 \\
10.186\end{array}$ & $\begin{array}{l}0.311 \\
(0.062)\end{array}$ & $\begin{array}{l}5.913 \\
(1.183)\end{array}$ & $\begin{array}{l}7.1 \\
(0.71)\end{array}$ & $\begin{array}{l}2.376 \\
(0.238)\end{array}$ & $\begin{array}{l}45.140 \\
(4.514)\end{array}$ \\
\hline $\begin{array}{l}\text { Fossil Fueled(b) } \\
\text { Power Plants }\end{array}$ & 8.9 & 2.09 & 11.83 & $\begin{array}{l}11.3 \\
(11.9)\end{array}$ & $\begin{array}{l}2.65 \\
(2.79)\end{array}$ & $\begin{array}{l}15.02 \\
(15.82)\end{array}$ & $\begin{array}{l}11.3 \\
(15.7)\end{array}$ & $\begin{array}{l}2.65 \\
(3.68)\end{array}$ & $\begin{array}{l}15.02 \\
(20.87)\end{array}$ \\
\hline $\begin{array}{l}\text { Nuc l ear Fue led (b) } \\
\text { Power Plants }\end{array}$ & 3.7 & 0.38 & 7.30 & $\begin{array}{l}3.9 \\
(4.5)\end{array}$ & $\begin{array}{l}0.41 \\
(0.47)\end{array}$ & $\begin{array}{l}7.70 \\
(8.88)\end{array}$ & $\begin{array}{l}2.6 \\
(7.05)\end{array}$ & $\begin{array}{l}0.27 \\
(0.73)\end{array}$ & $\begin{array}{l}5.13 \\
(13.91)\end{array}$ \\
\hline
\end{tabular}

(a) Contribution from central tower plants only. Based on percentages in Tables 13 and 14.

(b) Eout was calculated from Anpendix 4 based on efficiencies listed in Table 11.

$E_{\text {out }}=n E_{\text {in }}$ 


\section{TABLE 17. Summary of Energy and Waste Heat Generation Intermediate Growth/Establishment Scenario, Quadrillion Btu}

\begin{tabular}{|c|c|c|c|c|c|c|c|c|c|}
\hline \multirow{2}{*}{ Energy Type } & \multicolumn{9}{|c|}{ Year } \\
\hline & Fout & $\frac{1985}{00}$ & 01 & Fout & 2000 & तI & Fout & $\frac{2025}{00}$ & 01 \\
\hline Coal & & & & & & & & & \\
\hline Syn. Liquids & 0.2 & 0.017 & 0.059 & 7 & 0.584 & 2.071 & 12 & 1.001 & 3.550 \\
\hline $\begin{array}{l}\text { Coal } \\
\text { Syn. Gas, High Btu }\end{array}$ & 0.3 & 0.050 & 0.095 & 4 & 0.664 & 1.261 & 5 & 0.831 & 1.577 \\
\hline $\begin{array}{l}\text { Coal } \\
\text { Syn. Gas, Low and } \\
\text { Intermediate Btu }\end{array}$ & 0 & 0 & 0 & 10 & 0.750 & 1.750 & 14 & 1.050 & 2.450 \\
\hline $\begin{array}{l}\text { Coal } \\
\text { Clean Fue } 1\end{array}$ & 0.1 & 0.011 & 0.013 & 3 & 0.322 & 0.549 & 4 & 0.430 & 0.732 \\
\hline $\begin{array}{l}011 \text { Shale } \\
\text { Syn. Liquids }\end{array}$ & 0 & 0 & 0 & 8 & 1.321 & 3.082 & 17 & 2.807 & 6.550 \\
\hline Solar(a) & 0 & 0 & 0 & $\begin{array}{l}0.632 \\
(0.126)\end{array}$ & $\begin{array}{l}0.059 \\
(0.012)\end{array}$ & $\begin{array}{l}1.115 \\
(0.223)\end{array}$ & $\begin{array}{l}2.896 \\
(0.290)\end{array}$ & $\begin{array}{l}0.269 \\
(0.027)\end{array}$ & $\begin{array}{l}5.109 \\
(0.511)\end{array}$ \\
\hline Geothermal & 0.01 & 0.003 & 0.064 & $\begin{array}{l}0.85 \\
(0.17)\end{array}$ & $\begin{array}{l}0.284 \\
(0.057)\end{array}$ & $\begin{array}{l}5.404 \\
(1.081)\end{array}$ & $\begin{array}{l}7.5 \\
(0.75)\end{array}$ & $\begin{array}{l}2.510 \\
(0.251)\end{array}$ & $\begin{array}{l}47.683 \\
(4.768)\end{array}$ \\
\hline $\begin{array}{l}\text { Fossi1 Fue led }(b) \\
\text { Power Plants }\end{array}$ & 9.5 & 2.23 & 12.63 & $\begin{array}{l}13.7 \\
(14.3)\end{array}$ & $\begin{array}{l}3.21 \\
3.36\end{array}$ & $\begin{array}{l}18.21 \\
(19.01)\end{array}$ & $\begin{array}{l}11.3 \\
(16.0)\end{array}$ & $\begin{array}{l}2.65 \\
(3.75)\end{array}$ & $\begin{array}{l}15.02 \\
(21.27)\end{array}$ \\
\hline $\begin{array}{l}\text { Nucl ear Fue led }(b) \\
\text { Power'Plants }\end{array}$ & 3.9 & 0.41 & 7.70 & $\begin{array}{l}4.9 \\
(5.5)\end{array}$ & $\begin{array}{l}0.51 \\
(0.57)\end{array}$ & $\begin{array}{l}9.67 \\
(10.85)\end{array}$ & $\begin{array}{l}8.1 \\
(12.8)\end{array}$ & $\begin{array}{l}0.84 \\
(1.33)\end{array}$ & $\begin{array}{l}15.98 \\
(25.26)\end{array}$ \\
\hline
\end{tabular}

(a) Contribution from central tower plants only. Based on percentages in Tables 13 and 14. (b) $E_{\text {out }}$ was calculated from Appendix $A$ based on efficiencies listed in Table 11.
$E_{\text {out }}=n E_{\text {in }}$ 


\section{TABLE 18. Surmary of Energy and Waste Heat Generation High Growth/High Coal Scenario, Quadrillion Btu}

\begin{tabular}{|c|c|c|c|c|c|c|c|c|c|}
\hline \multirow[b]{3}{*}{ Energy Type } & \multicolumn{9}{|c|}{ Year } \\
\hline & \multicolumn{3}{|c|}{1985} & \multicolumn{3}{|c|}{2000} & \multicolumn{3}{|c|}{2025} \\
\hline & Eout & $Q D$ & QI & Eout & $Q 0$ & QI & Eout & $\overline{Q D}$ & QI \\
\hline $\begin{array}{l}\text { Coal } \\
\text { Syn. Liquids }\end{array}$ & 0.2 & 0.017 & 0.059 & 9 & 0.751 & 2.663 & 15 & 1.252 & 4.438 \\
\hline $\begin{array}{l}\text { Coal } \\
\text { Syn. Gas, High Btu }\end{array}$ & 0.3 & 0.050 & 0.095 & 5 & 0.831 & 1.577 & 8 & 1.329 & 2.523 \\
\hline $\begin{array}{l}\text { Coal } \\
\text { Syn. Gas, Low and } \\
\text { Intermediate Btu }\end{array}$ & 0.3 & 0.023 & 0.053 & 14 & 1.050 & 2.450 & 22 & 1.650 & 3.850 \\
\hline $\begin{array}{l}\text { Coal } \\
\text { Clean Fue } 1\end{array}$ & 0.1 & 0.011 & 0.013 & 5 & 0.537 & 0.915 & 8 & 0.859 & 1.463 \\
\hline $\begin{array}{l}\text { Oil Shale } \\
\text { Syn. Liquids }\end{array}$ & 0 & 0 & 0 & 10 & 1.651 & 3.853 & 20 & 3.302 & 7.705 \\
\hline Solar (a) & 0 & 0 & 0 & $\begin{array}{l}0.643 \\
(0.129)\end{array}$ & $\begin{array}{l}0.060 \\
(0.012)\end{array}$ & $\begin{array}{l}1.134 \\
(0.227)\end{array}$ & $\begin{array}{l}3.342 \\
(0.334)\end{array}$ & $\begin{array}{l}0.310 \\
(0.031)\end{array}$ & $\begin{array}{l}5.896 \\
(0.590)\end{array}$ \\
\hline Geothermal & 0.01 & 0.003 & 0.064 & $\begin{array}{l}0.99 \\
(0.198)\end{array}$ & $\begin{array}{l}0.331 \\
(0.060)\end{array}$ & $\begin{array}{l}6.294 \\
(1.259)\end{array}$ & $\begin{array}{l}7.5 \\
(0.75)\end{array}$ & $\begin{array}{l}2.510 \\
(0.251)\end{array}$ & $\begin{array}{l}47.683 \\
(4.768)\end{array}$ \\
\hline $\begin{array}{l}\text { Fossil Fueled (b) } \\
\text { Power Plants }\end{array}$ & 9.1 & 2.14 & 12.10 & $\begin{array}{l}16.4 \\
(17.1)\end{array}$ & $\begin{array}{l}3.85 \\
(4.01)\end{array}$ & $\begin{array}{l}21.80 \\
(22.73)\end{array}$ & $\begin{array}{l}19.5 \\
(24.4)\end{array}$ & $\begin{array}{l}4.58 \\
(5.73)\end{array}$ & $\begin{array}{l}25.93 \\
(32.44)\end{array}$ \\
\hline $\begin{array}{l}\text { Nuc lear Fue led (b) } \\
\text { Power Plants }\end{array}$ & 4.0 & 0.42 & 7.89 & $\begin{array}{l}6.5 \\
(7.2)\end{array}$ & $\begin{array}{l}0.68 \\
(0.75)\end{array}$ & $\begin{array}{l}12.83 \\
(14.2)\end{array}$ & $\begin{array}{l}12.4 \\
(17.3)\end{array}$ & $\begin{array}{l}1.29 \\
(1.80)\end{array}$ & $\begin{array}{l}24.47 \\
(34.13)\end{array}$ \\
\hline
\end{tabular}

(a) Contribution from central tower plants only. Based on percentages in Tables 13 and 14.

(b) Eout was calculated from Anpendix $A$ based on efficiencies listed in Table 11.

$E_{\text {out }}=n E_{\text {in }}$ 
TABLE 19. Distribution of Cooling Requirements Low Growth/Low Coal Scenario

\begin{tabular}{|c|c|c|c|c|c|}
\hline \multicolumn{2}{|c|}{1985} & \multicolumn{2}{|c|}{2000} & \multicolumn{2}{|c|}{2025} \\
\hline $\begin{array}{l}\text { QI } \\
\text { Quads }\end{array}$ & $\begin{array}{l}\text { Percent } \\
\text { of Total }\end{array}$ & $\begin{array}{c}\text { QI } \\
\text { Quads }\end{array}$ & $\begin{array}{l}\text { Percent } \\
\text { of Total }\end{array}$ & $\begin{array}{c}\text { QI } \\
\text { Quads }\end{array}$ & $\begin{array}{l}\text { Percent } \\
\text { of Total }\end{array}$ \\
\hline
\end{tabular}

Alternative Energy

- Geothermal

0.082

0.5

9.052

32.7

38.756

66.4

- Solar

(4.168)

(17.0) (9.210)

$(24.1)$

- Synfue 1s

Conventional

- Fossil fueled

- Nuclear

16.35

99.5

18.60

$67.3 \quad 19.57$

33.6

(20.40)

$(83.0) \quad(29.04)$

(75.9)

Tota 1

16.432

27.652

58.326

(24.568)

$(38.250)$

( ) Assumes the HI study is a factor of 5 too high for solar and geothermal contribution in the year 2000 and a factor of 10 too high in the year 2025.

TABLE 20. Distribution of Cooling Requirements Intermediate Growth/Populist Scenario

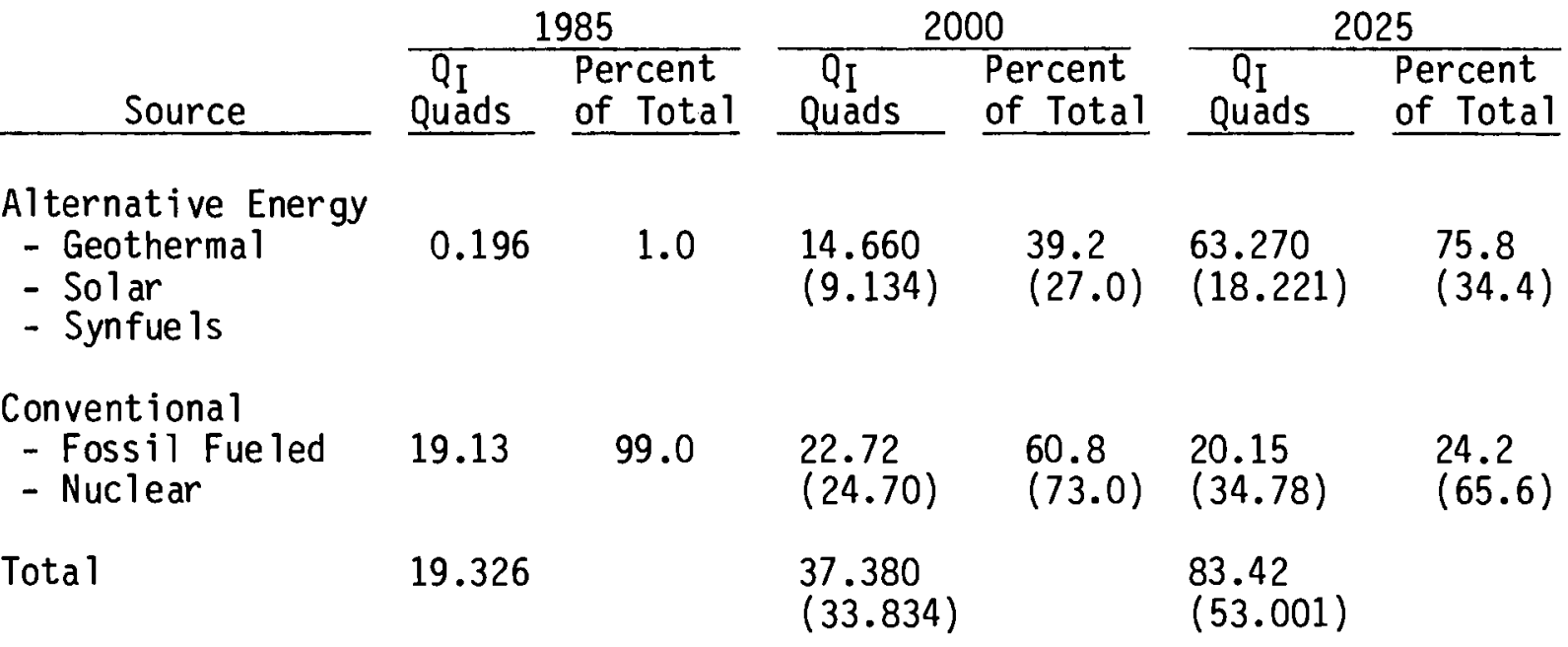

() Assumes the HI study is a factor of 5 too high for solar and geothermal contribution in the year 2000 and a factor of 10 too high in the year 2025. 
TABLE 21. Distribution of Cooling Requirements Intermediate Growth/Establishment Scenario

\begin{tabular}{|c|c|c|c|c|c|c|}
\hline \multirow{2}{*}{ Source } & \multicolumn{2}{|c|}{1985} & \multicolumn{2}{|c|}{2000} & \multicolumn{2}{|c|}{2025} \\
\hline & $\begin{array}{l}\text { QI } \\
\text { Quads }\end{array}$ & $\begin{array}{l}\text { Percent } \\
\text { of Total }\end{array}$ & $\begin{array}{c}\text { QI } \\
\text { Quads }\end{array}$ & $\begin{array}{l}\text { Percent } \\
\text { of Total }\end{array}$ & $\begin{array}{c}\text { QI } \\
\text { Quads }\end{array}$ & $\begin{array}{l}\text { Percent } \\
\text { of Tota }\end{array}$ \\
\hline $\begin{array}{l}\text { Alternative Energy } \\
\text { - Geothermal } \\
\text { - Solar } \\
\text { - Synfuels }\end{array}$ & 0.236 & 1.1 & $\begin{array}{l}15.232 \\
(10.017)\end{array}$ & $\begin{array}{l}35.3 \\
(25.1)\end{array}$ & $\begin{array}{l}67.651 \\
(20.138)\end{array}$ & $\begin{array}{l}68.6 \\
(30.2)\end{array}$ \\
\hline $\begin{array}{l}\text { Conventional } \\
\text { - Fossil fue led } \\
\text { - Nuclear }\end{array}$ & 20.33 & 98.9 & $\begin{array}{l}27.88 \\
(29.86)\end{array}$ & $\begin{array}{l}64.7 \\
(74.9)\end{array}$ & $\begin{array}{l}31.00 \\
(46.53)\end{array}$ & $\begin{array}{l}31.4 \\
(69.8)\end{array}$ \\
\hline Total & 20.566 & & $\begin{array}{l}43.112 \\
(39.877)\end{array}$ & & $\begin{array}{l}98.651 \\
(66.668)\end{array}$ & \\
\hline
\end{tabular}

( ) Assumes the HI study is a factor of 5 too high for solar and geothermal contribution in the year 2000 and a factor of 10 too high in the year 2025.

TABLE 22. Distribution of Cooling Requirements High Growth/High Coal Scenario

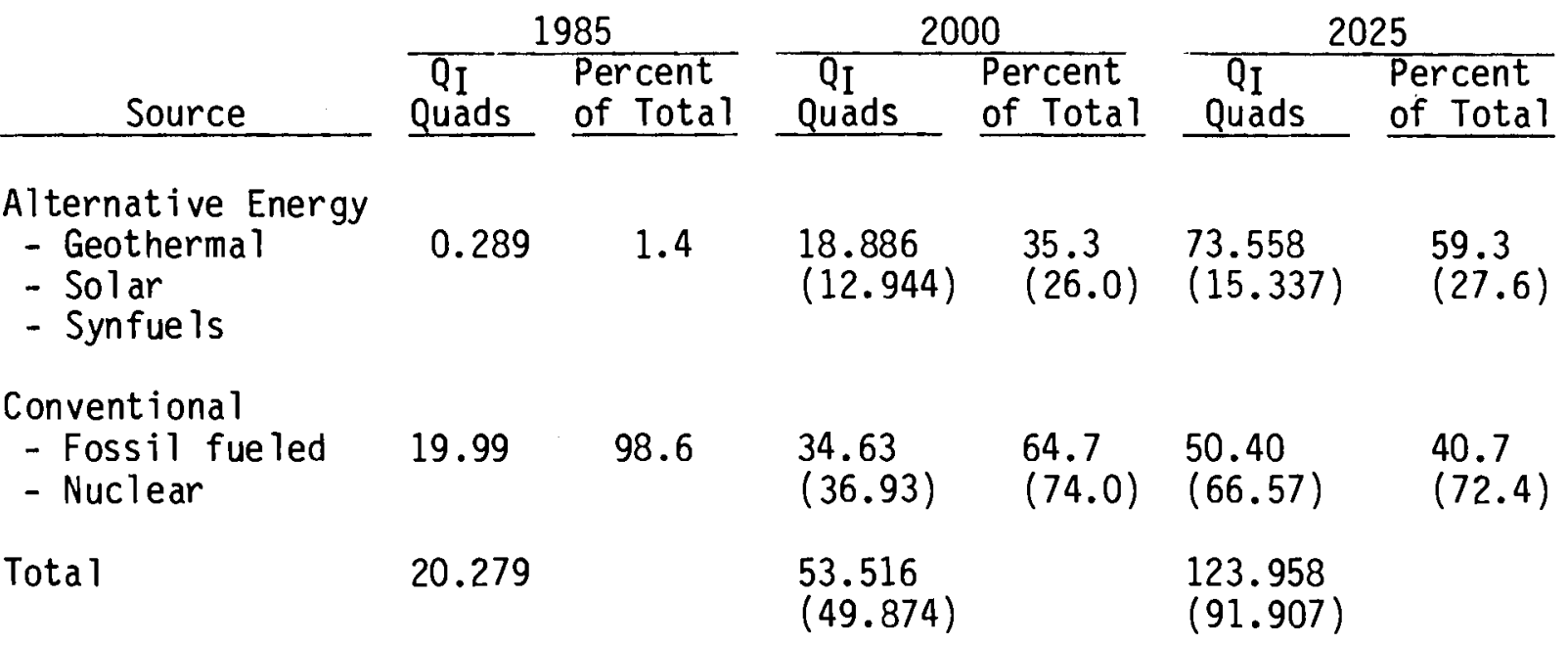

( ) Assumes the HI study is a factor of 5 too high for solar and geothermal contribution in the year 2000 and a factor of 10 too high in the year 2025 . 


\section{INCENTIVES FOR USING DRY COOLING}

Based on contemporary trends an understanding of the incentives to use dry cooling can be gained and expected requirements for dry cooling can be qualitatively assessed. There are three main considerations that can accelerate the use of dry cooling. They are: water availability problems, environmental concerns, and legal requirements.

\section{WATER AVAILABILITY}

When siting a power plant, water availability is the most important consideration (Ritchings and Lotz 1963). Anywhere from $60 \%$ to $90 \%$ of the raw energy brought into a power plant must be dissipated as waste heat. Typically, water has been used as the heat sink; consequently, all power plants will need to be located near a reliable source of cooling water, unless a method that does not use significant quantities of water can be employed. The U.S. Water Resources Council (1978) reports that approximately 4200 bgd (billion gallons per day) of water precipitate on the contiguous United States. Much of this water evaporates immediately leaving about 1450 bgd to accumulate in ground and surface storage; flow to the ocean, Gulf of Mexico, or across the nation's boundaries; to be consumptively used; or to be evaporated from reservoirs. of this potential $1450 \mathrm{bgd}$, on ly 675 bgd are considered available 95\% of the time.

In 1975 withdrawals were at 338.5 bgd. Withdrawals are projected to decrease to 306.4 bgd by the year 2000; however, water consumption is expected to increase from 106.6 bgd to 135.1 bgd in the same time frame. The decrease in withdrawal is based on assumed water use efficiency and recycling improvements. The dramatic increase in water consumption is due primarily to steam electric generation, agriculture, and the manufacturing and mineral industries. It is anticipated that problems of water for energy production will emerge first in the Missouri, Ohio, and Upper Colorado regions where large coal and oil shale deposits are located. The consumptive use of water for agricultural and municipal growth has been taking place at a rate proportional to the rate of growth of population, while consumptive use for industrial and utility 
plant growth is exponential (Hu 1976). The U.S. Water Resources Council projects that by the year 2000 inadequate surface water supply is or will be severe in 17 subregions that are located mainly in the Midwest and Southwest.

Two studies have been performed that estimate the need for wet/dry cooling through the year 2000 based on water availability. These studies only considered water use for nuclear and fossil fueled power plants.

One study, performed by the General Electric Company (1976), indicated that the following areas will be facing critical water supply problems for cooling use in thermal power plants:

- Texas Gulf region

- California

- Upper Colorado river basin

- Lower Colorado river basin

This study noted that the Texas Gulf region and California probably could obtain enough cooling water from ocean, waste, and ground water, thereby avoiding wet/dry cooling. The Colorado River basin, on the other hand, was projected to require 6 to 23 GWE of nuclear power plants that may require wet/dry cooling by the year 2000. In addition, a PNL study (Hendrickson 1978) determined that another 5 to 19 GWE from fossil fueled power plants may require wet/ drying cooling in this region. This indicates a total projected need of 11 to 42 GWE in the Colorado River Basin by the year 2000.

Another study was conducted by the Hanford Engineering Development Laboratory (Peterson and Sonnichsen 1976). This study looked at 217 river basins or water resource subregions in the United States and concluded that, except for a few isolated plants, no dry or wet/dry cooling will be required until 1990. Between 1990 and 2000 the following requirements for dry or wet/dry cooling were projected for nuclear and fossil fueled power plants: 


$\begin{array}{lr}\text { California } & 14-22 \text { GWE } \\ \text { Denver Area } & 2-5 \\ \text { Southern Great Plains } & 4-11 \\ \text { Upper Colorado River Basin } & 1-2 \\ \text { Lower Colorado River Basin } & 2-4 \\ \text { Great Basin } & -\frac{1}{44} \text { GWE } \\ \quad \text { Total } & 22\end{array}$

The difference in the low end of the estimates arises because the General Electric study assumed California could satisfy all of its cooling water requirements by the use of saline water and with water transfers, while the HEDL study assumed only $3 / 4$ of the water requirement could be met in this manner. Based on this information, Hendrickson 1978 concluded that it was reasonable to expect approximately $20 \mathrm{GWE}$ of wet/dry cooling to be required by the year 2000. Most of this will be in the Southwest.

\section{ENVIRONMENTAL}

Environmental concerns will ultimately lead to policy decision and regulation that make it difficult to use cooling methods that previously were in widespread use. The primary environmental problems are the large amounts of heat released to water bodies, entrainment of aquatic organisms in cooling water intakes, increased salinity, blowdown of cooling tower water containing water treatment chemicals and heat, and pollution from cooling tower drift.

The following is a list of critical environmental factors pertaining to power $\mathrm{plant}$ cooling systems that environmental impact statements are expected to address (U.S. Environmental Protection Agency 1973).

1. Rate of cooling water withdrawal, with respect to:

a. local and regional water supply and uses and the effect of proposed withdrawals thereon

b. entrainment and subsequent kill of planktonic organisms in passing through the condenser

2. Intake design and hydraulics with respect to entrapment and damage to fish 
3. Temperature $r$ ise across the condenser

4. Effluent mixing zone

a. a maximum temperature of discharge increase in temperature above natural

b. size and geometry

5. Land requirements for cooling systems, particularly ponds

6. Water loss

7. Local meteorological effects such as fog or ice

8. Drift characteristics and terrestrial impact

9. Chemical or physical cooling water treatment program

10. Blowdown

a. cycles (multiples) of concentration and flowrate

b. treatment and/or disposal

11. Overall minimization of waste discharge to water, air, and land

12. Cost implications of environmentally desirable refinements or alternatives.

Entrainment of organisms is a problem with cooling water intake. Aquatic organisms can be swept through the power plant cooling system and depending on such factors as the design, time and temperature of exposure, and the species of the organisms, certain fractions will be killed. Also, fish can be impinged on the screens protecting the plant inlet, or the fish can become trapped in the inlet structure. These problems are most of ten associated with oncethrough cooling since this method requires the highest withdrawal rate. Cooling tower plumes and the vapor from cooling ponds can cause or increase fog and ice conditions. Usually this is not a problem but under certain weather conditions fog or ice can occur. Another problem that is associated with cooling towers is called drift. Drift consists of droplets of water from wet cooling towers that are entrained by the moving air. In contrast to the water vapor that is evaporated from the cooling water, drift can contain pollutants. These pollutants may consist of chemicals used for cooling water treatment or in the case of saline water cooling towers, the drift will contain salts that may be deposited on the surrounding area. 
Blowdown from towers and ponds also has an environmental problem associated with it. Since ponds and towers have a high consumptive use of water, the salinity of the water is increased; consequently, the water that is used for blowdown is more saline than the original water source. The purpose of blowdown is to keep the cooling water concentration at an acceptable level. However, the blowdown water can increase the salinity of the receiving water.

A final environmental problem is the thermal load placed on water bodies. This is a significant problem with once-through cooling since this system requires that all the heat be absorbed by the water body. This results in potentially detrimental physical and biological changes to the water body. As the temperature of water is increased, its ability to hold dissolved oxygen decreases. Since oxygen is required for respiration of most living organisms, for adequate bacterial decomposition of organic matter, and for chemical oxidation, the lower availability of oxygen can have significant impact on the ecology of a water body. In addition, the increased bouyancy of heated water can cause stratification.

All of these environmental problems serve as incentives for the use of dry cooling or wet/dry cooling since the environmental impacts of the dry cooling technologies can be significantly less. It has been suggested that there may be a beneficial effect from dry towers due to increased ventilation in inversion prone areas (U.S.EPA 1973). However, there may be the potential of weather modifications by dry towers, such as triggering cumulus cloud formation, and it has been suggested that the meteorological consequences of large heat releases should be assessed (U.S.EPA 1973). The problem of large heat releases is associated with all cooling methods. Either directly or indirectly all cooling systems result in the addition of heat to the atmosphere and ultimately this heat is dissipated to space.

\section{LEGAL}

There are many legal constraints which can affect the feasibility of using a particular cooling method. These constraints generally fall into two 
categories: 1) laws and regulations that set permissible levels of pollutants (this includes heat) in waterbodies and 2) constraints affecting the legal availability of water.

The Federal Water Pollution Control Act Amendments of 1972 (FWPCA) have had significant impact on cooling system selection. The FWPCA set a goal of eliminating all discharge of pollutants (including heat) into navigable water by 1980 . This resulted in a number of EPA regulations that were designed to force all new generating plants to utilize some kind of closed cycle cooling system if they were put on line after January 1, 1974, or if the plant was larger than 500 MWE and was put on line after January 1, 1970. In addition, the only heat discharge that would be allowed from new steam electric plants would be from blowdown of the recirculated cooling water or from blowdown of cooling ponds. These EPA requirements were subsequently set aside in a court case, leaving the status of once-through cooling in limbo. It appears, however, that closed cycle cooling will be the rule for future power plants, especially for inland sites (Hendrickson 1978).

The decision to use dry cooling is likely to be primarily affected by an inability to obtain adequate water. The laws and regulations controlling transfer of water rights are quite complex and vary from place to place, and may even be specific to a given water basin. Briefly, there are two basic doctrines covering acquisition of water rights. They are: the appropriation system, and riparian rights. These basic concepts have then been further modified depending on the given area. The appropriation system states that the first person to make use of the water has prior rights to that water. In other words, if a stream is over appropriated, the first user has the right to use the water he needs; the second person then takes $h$ is share, and so on until the water is used up. Those with the most recent water rights may get no water at all. An appropriation right can be lost through nonuse.

In the riparian system, the water right is based on ownership of land that is in contact with the water. The water must be used on the riparian 1 and and the use must be reasonable with the use of other riparian owners. 
Hendrickson (1978) has evaluated the various means by which a utility might acquire water rights. He concludes that except for water from Federal reclamation and storage projects, acquisition of new water rights in the west is not likely to be a significant source of water. Many of the Western states have streams that are fully appropriated and the paper rights exceed the yield of the stream. In other states where water is not fully appropriated, utilities may have trouble obtaining rights of sufficient quantity and seniority. Another source of water rights may be the transfer of existing water rights to an alternative use. Generally, this is a possible alternative; however, some states such as California, Montana, and North Dakota have restrictions on transferring agricultural quality water to industrial uses.

Another source of water is the ground-water resource. This resource is covered by four water law systems. In most of the East, Midwest, and Texas a landowner is allowed to pump as much water as he wants; however, pumping permits may be required. A modification of this law is a reasonable-use rule that is similar to the riparian surface-water system. A second modification is the correlative-right rule which basically allocates a share of the ground water that is proportional to the landowner's surface ownership. The fourth system is the prior appropriation system which applies in the majority of the Western states.

Ground-water use is often restricted. For example, California can require prorata cut-backs if an aquifer is overdrawn, while other states have quota systems which may exclude new users. Still other states prohibit mining of ground water (withdrawing faster than the recharge rate).

Hendrickson has identified the following three legal uncertainties affecting the acquisition of water: Indian water rights, other Federal reserved rights, and preservation of instream water. The uncertainties associated with Indian water rights and other Federal reserved rights is due to the implicit reservation doctrine. This doctrine states that when public lands are set aside by Congress for special use such as national parks, forests, and Indian reservations, enough of the water originating on or flowing over the land is 
also reserved by implication. This leaves many questions unanswered such as: How much water has been reserved? Where can this water be used? For what purposes can this water be used? Until these questions are resolved, a great deal of uncertainty will remain as to water availability in some areas. Most of the reserved land was set aside in the latter part of the 19th Century; consequently, few prior claims to the water exist. This means that fairly large amounts of water can come under the influence of the implicit reservation doctrine. A Supreme Court case in 1963 determined that five Indian reservations in Arizona, California and Nevada were entitled to approximately 1 million acre-ft annually, which constitutes about $15 \%$ of the available water supply in the lower Colorado River Basin.

Recently there has been a trend toward preserving instream water for aesthetic, recreation, and fish and wildlife purposes. The National Wild and Scenic Rivers Act of 1968 states that no Federal agency may assist in a water resource project which would have a direct and adverse effect on the natural river value as determined by the Management Agency. Upstream and downstream of the protected area development may be allowed if no unreasonable impacts will occur. Also, at the state level, administrative steps and/or legislative actions are being taken to preserve instream water. 


\section{ENERGY TECHNOLOGIES AND DRY COOLING REQUIREMENTS}

A combination of many factors leads to the need for dry cooling when producing energy. Each energy-producing technology (geothermal, solar, or synthetic fuels) has different requirements which affect the potential for use of dry cooling.

Table 23 summarizes the amount of energy produced by energy technologies that may require large dry cooling towers. Since power plants are the only energy technology likely to require this type of cooling, only solar central tower and geothermal electric plants have been considered. Since solar central tower plants are likely to be located primarily in the arid Southwest perhaps $50 \%$ of the solar central plants will be dry cooled. Geothermal plant siting restrictions, possible ground subsidence problems, and scarcity of water in many of the geothermal resource areas in conjunction with the performance penalties associated with dry cooling low efficiency plants suggest that possibly $10 \%$ of the geothermal electric power plants will be dry cooled. These assumptions were used to arrive at the values in Table 23.

In summary Table 23 indicates that around 13 GWe produced by alternative energy technologies will require dry cooling in the year 2000 . This is reduced to approximately 2.5 GWe if the HI study values are reduced by a factor of 5 . Comparing this with the 11 to 44 GWe of nuclear and fossil fueled power plant generation expected to require dry cooling in the year 2000 (Hendrickson 1978) indicates that an additional 30\% to $118 \%$ increase in dry cooling over that required by conventional fueled plants may be required in the year 2000 . The increase may be as low as $6 \%$ to $23 \%$, however. In the year 2025, 44 to 81 GWe of alternative energy production may require dry cooling. If the $H I$ study is high by a factor of 10 , however, 4.5 to 8 GWe may require dry cooling.

A more detailed discussion of the dry cooling requirements for geothermal and solar energy is provided below. Dry cooling requirements for synthetic fuels production are also given. 
TABLE 23. Energy Production Requiring Dry Cooling, GWe ${ }^{(a)}$

\begin{tabular}{|c|c|c|c|c|c|c|c|c|}
\hline & \multicolumn{2}{|c|}{$\begin{array}{l}\text { Low Growth/Low } \\
\text { Coal Scenario }\end{array}$} & \multicolumn{2}{|c|}{$\begin{array}{l}\text { Intermediate Growth/ } \\
\text { Popul ist Scenario }\end{array}$} & \multicolumn{2}{|c|}{$\begin{array}{l}\text { Intermediate Growth/ } \\
\text { Establishment Scenario }\end{array}$} & \multicolumn{2}{|c|}{$\begin{array}{l}\text { High Growth/High } \\
\text { Coal Scenario }\end{array}$} \\
\hline & 2000 & 2025 & 2000 & 2025 & 2000 & 2025 & 2000 & 2025 \\
\hline $\begin{array}{l}\text { Solar Central } \\
\text { Tower Plants }\end{array}$ & $\begin{array}{c}9.66 \\
(1.94)\end{array}$ & $\begin{array}{l}27.95 \\
(2.79)\end{array}$ & $\begin{array}{c}9.13 \\
(1.89)\end{array}$ & $\begin{array}{l}46.58 \\
(4.67)\end{array}$ & $\begin{array}{l}10.57 \\
(2.11)\end{array}$ & $\begin{array}{l}48.43 \\
(4.85)\end{array}$ & $\begin{array}{l}10.75 \\
(? .16)\end{array}$ & $\begin{array}{l}55.89 \\
(5.59)\end{array}$ \\
\hline $\begin{array}{l}\text { Geothermai } \\
\text { Electric }\end{array}$ & $\begin{array}{r}2.68 \\
(0.54) \\
\end{array}$ & $\begin{array}{l}15.72 \\
(1.57)\end{array}$ & $\begin{array}{l}3.11 \\
(0.62)\end{array}$ & $\begin{array}{l}23.75 \\
(2.37)\end{array}$ & $\begin{array}{r}2.84 \\
(0.57) \\
\end{array}$ & $\begin{array}{l}25.09 \\
(2.51)\end{array}$ & $\begin{array}{c}3.31 \\
(0.66) \\
\end{array}$ & $\begin{array}{l}25.09 \\
(2.51)\end{array}$ \\
\hline Total & $\begin{array}{l}12.34 \\
(? .48)\end{array}$ & $\begin{array}{l}43.67 \\
(4.36)\end{array}$ & $\begin{array}{l}12.24 \\
(2.51)\end{array}$ & $\begin{array}{l}70.33 \\
(7.04)\end{array}$ & $\begin{array}{l}13.41 \\
(? .68)\end{array}$ & $\begin{array}{l}73.52 \\
(7.36)\end{array}$ & $\begin{array}{l}14.06 \\
(2.82)\end{array}$ & $\begin{array}{l}80.98 \\
(8.10)\end{array}$ \\
\hline
\end{tabular}

( ) - values based on the assumption that the HI study is a factor of 5 high in the year 2000 and a factor of $10 \mathrm{high}$ in the year 2025.

(a) Based on Eout values from tables 15 throush 18 assuming 50 of the solar central tower power plants and 10 of the qeotherinal electric nower plants will be dry cooled.

\section{GEOTHERMAL}

Geothermal production of electricity is more severely affected by the performance penalties associated with dry cooling than other generation systems. The greatest potential at present, however, for geothermal is in relatively hot, water-short regions of the country, such as the Imperial Valley in California.

Due to the relatively low temperature of geothermal resources, the efficiency of the power plants is quite low (10\% to 15\%). Therefore, the efficiency of the plants is much more sensitive to the heat sink temperatures than conventional power plants. This is apparent when analyzing the Carnot efficiency term, $n=\left(T_{j}-T_{0}\right) / T_{j}$. For relatively low source temperatures $\left(T_{j}\right)$ a small change in the sink temperatures $\left(T_{0}\right)$ will have a significant effect on the efficiency $(n)$. If, on the other hand, the source temperature is quite high, the same small change in the sink temperature will have a lesser effect on the efficiency. This significantly influences the performance of a geothermal plant with dry cooling where the heat sink temperature is determined by the dry bulb temperature. The dry bulb temperature is normally much higher than the wet bulb temperature that tends to $f i x$ the sink temperature for wet cooling. 
For flashed steam and dry steam resources, the steam condensate can be used as a source of quite pure cooling water. Thus, these plants will not require a source of cooling water as long as reinjection rates balancing withdrawal rates are not required. It may be desirable or necessary to perform balanced withdrawal and reinjection if ground subsidence becomes a problem. Plants in the Imperial Valley are already required to tie into a ground subsidence detection network although reinjection is not required at present.

If balanced withdrawal and reinjection becomes a requirement, dry towers or an auxiliary cooling water source will be necessary. If this is a requirement, dry cooling may be the only recourse since water is unlikely to be available and the power plants must be located at the resource.

In the case of binary cycle plants, dry cooling is even more likely to be used. In a binary cycle all of the geothermal fluid is reinjected; therefore, an auxiliary cooling water source will be required. Robertson (1978) indicates that the geothermal industry is likely to need large dry cooling towers well in advance of other generating $\mathrm{plants}$ and may we 11 have to develop much of th is technology.

Robertson (1978) cites a study that compared the costs of running a base loaded (constant power output) plant with wet cooling to a variable power output (also called floating power) plant with dry cooling. Both plants were considered to be 50 MWE geothermal binary cycle plants. The variable output concept basically allows the plant to run at full output all the time (determined by the climatological conditions affecting the cooling tower), while the constant power output method (which is the standard method of operation) sizes the $p 1$ ant such that it can generate its rated capacity during the most adverse weather conditions likely to occur. As a result, most of the time the plant will generate less power than it is actually capable of generating. The floating power concept is favored by certain operating characteristics. If there are large swings in the cooling water temperature, if the plant has higher than average condensing temperature, and if the plant efficiency is low, the use of floating power can be advantageous. The use of dry cooling will typically 
result in wide swings in the cooling water temperature since the dry bulb temperature fluctuates over a wider range than the wet bulb temperature. Also, since the dry bulb temperature is higher than the wet bulb temperature, the condensing temperature will tend to be higher. These factors along with the relatively low efficiency of geothermal plants indicate that the use of floating power with a dry cooled geothermal plant could be feasible. The study cited by Robertson indicates about a 10\% lower plant cost for a dry cooled floating power geothermal plant than for a fixed capacity wet cooled plant, and concludes that geothermal binary cycle power plants with dry cooling can be as economic as a base-loaded wet cooled plant.

A study performed by United Engineers is also discussed by Robertson (1978). This study examined the effects of using wet/dry cooling on a proposed geothermal plant at Heber in the Imperial Valley, California. The original design utilized evaporative cooling, but the scarcity of water in the Imperial Valley prompted the additional study. The significant results of this report were that if the water consumption is reduced to $40 \%$ of all wet cooling, the capital costs of the waste heat rejection system will be 1.5 times higher, the tota 1 plant costs after operating and capacity penalties are applied will be three times greater, and the total cost to generate electricity will be 1.4 times greater. If the water consumption is reduced to $5 \%$ of wet cooling, the heat rejection system costs will be six times greater and the total cost to produce electricity will be 1.6 times greater. The study further concludes that relatively small geothermal power plants tied into large power grids might operate more economically using conventional towers rather than wet/dry towers with base-loaded operation practiced only in the winter months. During adverse weather conditions the capacity would be allowed to drop off or the plant would be shut down completely.

SOLAR

Since solar central tower plants should have efficiencies in the range of $30 \%$ to $40 \%$, their waste heat rejection characteristics will be comparable to nuclear or fossil fueled power plants. An important siting consideration for 
solar plants, however, is the availability of incident solar energy. The region in the U.S. having the greatest solar power availability is the Southwest and, not surprisingly, the water supply deficiencies in the Southwest are considered critical due to both quality and quantity problems (Backus and Brown 1976). Thus, dry cooling is a natural consideration in this case.

A study by the Aerospace Corporation (1975) used the relatively high solar insolation values in the Southwest (including all or part of California, Nevada, Arizona, New Mexico, Utah, Colorado, Texas, and Oklahoma) as the major reason for choosing this region as the primary study area for solar thermal application. The study indicates that water availability problems in the lower Colorado River Basin would limit potential power generation at around $60,000 \operatorname{MWE}(1.79 / \mathrm{Q} /$ year) if wet towers are assumed. Since the ir analysis indicates that even under stringent siting criteria suitable land area is available for 2,150,000 MWE (64.3 Q/year), they assume dry cooling towers for their technical and economic evaluation.

Another report indicates that solar thermal conversion systems can be competitive with fossil fueled sources in the 1980s, particularly if they are sited in the southwestern United States (Bereny 1977). A secondary advantage gained by using dry towers with a solar central tower plant is the elimination of drift and plumes associated with a wet tower. Minerals contained in the tower drift could degrade performance if deposited on the mirror surface. The tower plume could also block or reduce the incident solar energy. In any case, water molecules attenuate the insolation even if no plume forms (Martin Marietta Corporation 1977 ).

\section{SYNTHETIC FUELS}

The primary factor prompting the use of dry cooling for synthetic fuel manufacturing is the lack of water in most of the regions where these plants are likely to be located. Probste in and Gold (1978) performed a study where in the five principal coal regions and the principal oil shale region in the country were analyzed to see if the water supply could support an assumed synthetic fuel industry. The six regions studied consisted of three Western 
coal regions, one oil shale region, and two Eastern coal regions. The Western coal and oil shale regions lie roughly along a band starting at the eastern Montana/western North Dakota border and extending generally southwesterly to the Four Corners region of the nation. The primary regions identified are: The Fort Union region, Powder River Basin, Green River Basin (oil shale), and the Four Corners region. The two Eastern coal regions studied are the Appalachian Basin and the Illinois Basin.

The study analyzed the available surface water (based on average flow and prior water commitments) in each of these regions and compared this with the expected water consumption for an assumed production of $5.8 \times 10^{12} \mathrm{Btu} /$ day of synthetic fuel in each of the regions, a total synthetic fuel production of $34.8 \times 10^{13}$ Btu/day or $12.7 / Q / y r$. Tables 24 and 25 summarize the findings. The ranges indicated for the coal conversion technologies are based on the amount of wet cooling used, from minimum practical wet cooling to high wet cooling. For oil shale conversion an intermediate amount of wet cooling was assumed and the variation is due to the method of spent shale disposal. The water consumption figures used to develop the percentages include other water uses than just for cooling.

TABLE 24. Water Consumption as a Percentage of Available Surface Water to Convert Coal to an Equivalent $5.8 \times 10^{12}$ Btu/day of Product (Probstein and Gold 1978)

\begin{tabular}{|c|c|c|c|c|}
\hline Region & $\begin{array}{c}\text { Available } \\
\text { Surface Water (a) } \\
\left(10^{6} \text { gal/day }\right) \\
\end{array}$ & \multicolumn{3}{|c|}{$\begin{array}{c}\text { Percent of Available Surface Water } \\
\text { Coal Coal } \\
\text { Gasification Liquefaction Clean } \\
\text { Coal }\end{array}$} \\
\hline Powder River & 890 & 8.4 to 13.7 & 7.2 to 11 & 3.3 to 6.5 \\
\hline Fort Union & 1,790 & 4.2 to 6.8 & 3.6 to 5.5 & 1.6 to 3.2 \\
\hline Four Corners & 60 & (b) & (b) & $98^{(b)}$ \\
\hline $\begin{array}{l}\text { Appalachian and } \\
\text { Illino is Basins }\end{array}$ & 230,000 & 0.066 to 0.10 & $\begin{array}{l}0.056 \text { to } \\
0.086\end{array}$ & $\begin{array}{l}0.026 \text { to } \\
0.050\end{array}$ \\
\hline
\end{tabular}

(a) Average annual values

(b) Greater than available water supply by a factor of about 1.5 to 2.5

(c) Two million barrels/day of synthetic crude or its equivalent of $11.6 \times 1012 \mathrm{Btu} / \mathrm{day}$ 
TABLE 25. Water Consumption to Convert 0 il Shale to $1 \times 10^{6}$ barrels/day of Synthetic Crude (Probstein and Gold 1978)

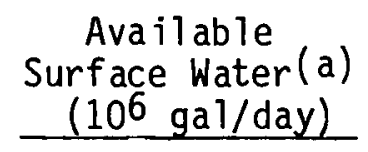

210

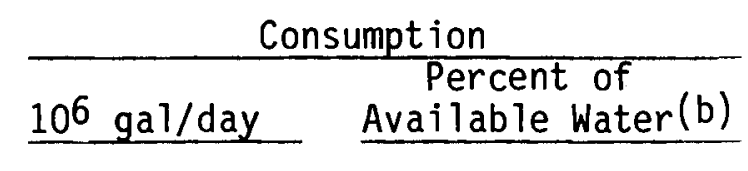

110 to 180

52 to 86

(a) Average annual value

(b) Green River Formation (Colorado and Utah)

Examination of Tables 24 and 25 indicates that the assumed production levels would not be achievable in the Four Corners region and it is unlikely that the higher water consumption for oil shale development could be met. The other water consumption values are not insignificant. The energy projections discussed previously predict a coal/synthetic fuels production of between 8 and $33 \mathrm{Q} / \mathrm{yr}$ in the year 2000 and between 14 and $53 \mathrm{Q} / \mathrm{yr}$ in the year 2025 .

$0 i 1$ shale is also expected to produce between 3 and $10 \mathrm{Q} / \mathrm{yr}$ in the year 2000 and between 7 and $20 \mathrm{Q} / \mathrm{yr}$ by the year 2025. These production levels are significantly higher than the assumed synthetic fuel production level of 12.7 Q/yr that Tables 24 and 25 are based on. Realistically, not all the oil shale would be produced from the Green River formation, although this is the highest grade oil shale deposit in the United States, and not all the coal/ synthetic fuels would be produced in only the five coal regions studied. Additionally, water problems will possibly result in development in less water short regions first.

The high water consumption associated with the projected synthetic fuel production levels indicates that dry cooling will be desirable, perhaps even mandatory, to achieve a high level of synthetic fuel production. 


\section{REFERENCES}

Aerospace Corporation, Energy and Resources Division. January 1975. Solar Thermal Conversion Mission Analysis. Vol. 1. Summary Report: Southwestern U.S. Report No. PB-242-898.

Allemann, R. T., B. M. Johnson, and G. C. Smith. September 1976. Ammonia as an Intermediate Heat Exchange Fluid for Dry Cooled Towers. BNWL-SA-5997.

Backus, C. E., and M. L. Brown. July 1976. "Water Requirements for Solar Energy." J. Am. Water Works Assoc. 68:366-369.

Ben-David, S., F. L. Brown, Jr., H. G. Folster and E. F. Thode. June 1974. Analysis of Water Characteristics of Manufacturing Industries and The ir Adaptability to Semi-Arid Regions. Technical Completion Report. New Mexico State University, University Park; Office of Water Resources Research, Washington, DC. Water Resources Scientific Information Center; New Mexico University, Albuquerque, NM.

Bennington, G., P. Curto, G. Miller, K. Rebibo and P. Spewak. March 1978. Solar Energy - A Comparative Analys is to the Year 2020. The MITRE Corp., McLean, VA, MTR-7579.

Bereny, J. A. 1977. Survey of the Emerging Solar Energy Industry. Solar Energy Information Services, San Mateo, CA.

Cande 1a, B. J., A. J. Wiener et al., and Hudson Inst. Inc. August 1975. Issues Relative to the Development and Commercialization of a Coal Derived Synthet ic Liquids Industry, Task 5: "Lifestyle and Energy Consumption: Scenarios for the Years 1985, 2000 and 2025." FE-1752-1, Prepared for the U.S. Energy Research and Development Administration.

Candela, B. J., W. M. Brown and Hudson Inst. Inc.. May 1977. Issues Relative to the Development and Commercialization of a Coal-Derived Synthet ic Liquids Industry. The Role of Synthetic Liquid from Coal in Meet ing Future Energy Demands. Final Report, January 1975 - December 1976. Report No. FE-1752-14. Hudson Inst., Inc., Croton-on-Hudson, NY.

Caputo, R. S. and V. C. Trusce 11o. 1976. Solar Thermal Electric Power Plants: Their Performance Characteristics and Total Social Costs. Intersoc. Energy Convers. Eng. Conf., 11th Proc., State Line, NV, September 12-17, 1976. Publ. by AICHE, New York, NY. Vol. 2 SAE Paper 769213 , p. $1216-1223$.

"Cooling Without Water - A Bristling Challenge as Water Supplies Dwindle." March 1973. Power. 117:5.1-5.24.

Crutchfield, H.C. 1970. The Power Industry's Requirement for Cooling Towers. Utah Power and Light Co. 
Edmonds, P. R., H. K. Loffman and R. C. Maxwe11. 1975. Some Terrestrial Considerations Associated with Cooling-Tower Systems for Electric Power Generation. In: Cooling Tower Environment, 1974, U.S. Energy Research and Deve Topment Administration.

Ermak, D. L. September 30, 1977. Potential Growth of Electric Power Production from Imperial Valley Geothermal Resources. Calif. Univ., Livermore, CA. Lawrence Livermore Lab. Report No. UCRL-52252.

Ermak, D. L. April 1978. "Scenario for Geothermal Electric Power Development in Imperial Valley." Energy (0xford). 3(2):203-217.

Federal Energy Administration. 1976. National Energy Outlook. FEA-N-75/713.

Federal Power Commission. December 1971. The 1970 National Power Survey, Part I.

General Electric Co., San Jose, CA. February 1976. Future Needs for Dry or Peak Shoved Dry/Wet Cooling and Significance to Nuclear Power Plants. EPRI NP-150, Prepared for the Electric Power Research Institute, Palo A1to, CA.

Griffin, Robert J. July 9, 1979. The Sun: An Alternate Energy Source. Energy Insider, U.S. Department of Energy. 2(14).

Harrington, W., D. Abbey and J. W. Sawyer, Jr. August 1977. Electric Power and Synthetic Fuels Industries in the Southwest: Production and Environmental Control Technologies.

Hendrickson, P. L. September 1978. An Overview of Issues Affecting the Demand for Dry and Wet/Dry Cooling for Thermal Power Plants. BNWL-2268-REV, Battelle, Pacific Northwest Laboratory, Richland, WA.

Hu, M. C., et al. November 1976. Engineering and Economic Evaluation of Wet/Dry Cooling Towers for Water Conservation. United Engineers and Constructors, Inc., Philadelphia, PA, UE\&C-ERDA-761130.

Jimeson, R. M., and G. G. Adkins. July 1971. "Waste Heat Disposal in Power Plants." Chemical Engineering Process. 67:64-69.

Jónsson, U. K. 1976. Geothermal Power Utilization, Present and Future. In Alternative Energy Sources, Academic Press. pp. 279-324.

Kruger, P., and C. Otte, Editors. 1973. Geothermal Energy. Stanford University Press, Stanford, CA.

Kruger, P., and V. Roberts. November 1978. "Utility Estimates of Geothermal Electricity Generating Capacity." Aware. 98:13-15. 
Martin Marietta Corp. April 1977. Central Receiver Solar Thermal Power System, Phase I: Preliminary Design Report. Volume VI. Electrical Power Generation/Master Control Subsystems and Balance of Plant.

Maslan, Frank, T. J. Gordon, J. Stover. May 20-29, 1975. Technology Forecast of United States Geothermal Energy Resource Development. Proc. Second United Nations Symposium on the Development and Use of Geothermal Resources, San Franc isco, CA, Vol. 3, p. 2409.

Mathew, P. 1973. "Geothermal Operating Experience at Geysers Power Plant. Journal of the Power Division, ASCE. 99(P02):329-330.

Peterson, D. E, and J. C. Sonnichsen. September 1976. Assessment of the Requirements for Dry Towers. HEDL-TME-76-82, Hanford Engineering Development Laboratory, September 1976.

Probstein, R. F., and H. Gold. 1978. Water in Synthetic Fuel Production, The Technology and Alternatives. MIT Press.

Rex, Robert. July 1978. "U.S. Geothermal Ind. in 1978." Geothermal Energy. $\underline{6}(7): 28$.

Ritchings and Lotz. May and June 1963. "Economics of Closed Versus Open Cooling Water Cycles." Power Eng.

Robertson, R. C. December 1978. Waste Heat Rejection from Geothermal Power Stations. Oak Ridge National Laboratory, Oak Ridge, TN. ORNL/TM-6533.

University of Oklahoma. May 1975. "The Science and Public Policy Program, Energy Alternatives: A Comparative Analys is.

U.S. Dept. of Commerce. February 1975. Commerce Technical Advisory Board, CTAB Recommendations for a National Energy Program, Appendix 5.

U.S. Department of Energy. April 1979. Energy Information Administration, Analys is Report, Energy Supply and Demand in the Midterm: 1985, 1990 and 1995. Report No. DOE/EIA-0102/52.

U.S. Department of Energy. 1978. Energy Information Administration, Annual Report to Congress 1978. Vol. 3, Report No. DOE/EIA-0173/3.

U.S. Dept. of the Interior. Apri1 1975. Westwide Study Report on Critical Water Problems Facing the Eleven Western States.

U.S. Environmental Protection Agency. October 1973. Reviewing Environmental Impact Statements - Power Plant Cooling Systems, Engineering Aspects.

EPA-660-2-73-016. 
U.S. Water Resources Counci1. December 1978. The Nation's Water Resources, 1975-2000. Second National Water Assessment, Vol. 1: Summary.

Vant-Hu11, L. L. June 1977. Liquid Sodium Cooled Solar Tower System. Proceedings of the Annual Meeting - Am. Sect. of the Int. Solar Energy Soc., Vol. 1, Orlando, FL, June 6-19, 1977. Publ. by Am. Sect. of the Int. Solar Energy Soc., Cape Canavera1, FL, Sect. 20, Sess. B.3. 


\section{BIBLIOGRAPHY}

At las Corporation. February 1977. Environmental Assessment Methodology and Solar Plant Applications. Semi-annual EPRI Solar Program Review Meeting and Workshop, Fallmouth, MA, October 6, 1976. Report No. EPRI-ER-371-SR. pp. 6.1-6.35.

Archer, D. H., D. L. Keairns and E. J. Vidt. 1974. "Development of a Fluidized Bed Coal Gasification Process for Electric Power Generation." Paper presented at the 4th Synthetic Fuel from Coal Conference, Oklahoma State University, Stillwater, OK, March 6-7, 1974.

Atwood, Mark T. 1973. "The Production of Shale 0il." Chem. Tech. (October 1973):617-620.

Austin, A. L., G. H. Higgens and J. H. Howard. 1973. The Total Flow Concept For Recovery of Energy from Geothermal Hot Brine Deposits. Lawrence Livermore Laboratory, Lawrence, CA.

Austin, A. L. 1975. Prospects for Advances in Energy Conversion Technologies for Geothermal Energy Development. Proc. Second United Nations Symposium on the Development and Use of Geothermal Resources, San Francisco, CA, May 20-29, 1975, Vol. 3, pp. 1925-1935.

Aynsley, Eric. 1970. Cooling Towers, The Environment, and the Future. Research Institute, 1970. Cooling Tower Institute Paper No. TP88A.

Battelle Columbus and Pacific Northwest Laboratories. 1973. Environmental Considerations in Future Energy Growth, Vol. I: Fuel/Energy Systems: Technical Summaries and Associated Environmental Burdens, for the Office of Research and Development, Environmental Protection Agency. Battelle Columbus Laboratories, Columbus, $\mathrm{OH}$.

"Big Synthetic 0il Industry Seen Vital." $0 i 1$ and Gas Journal. 65(10):69, 1967.

B lake, F. A. 1975. 100 MWe Solar Power Plant Design Configuration and Performance. AIAATAAS (Am. Astronaut. Soc.) Sol. Energy for Earth Conference Paper No. 75-623, Los Angeles, CA, April 21-24, 1975. Published by AIAA, New York, NY.

Bloomster, C. H., et al. February 1975. GEOCOST: A Computer Program for Geothermal Cost Analys is, BNWL-1888, Battelle, Pacif ic Northwest Laboratory, Richland, WA.

Boehm, R., R. Bliss, H. Jacobs, and D. Kelley. 1976. Direct Contact Heat Exchangers for Geothermal Power Plants. Intersoc. Energy Convers. Eng. Conf., 11th Proc., State Line, NV, September 12-17, 1976. Published by AIChE, New York, NY, Vol. 1, Paper 769131, p. 754-760. 
Burton, D. C., Y. K. Ahn, and R. N. Abrams. 1976. Why, When, and How of Coal Gasification. Trans. Am. Nuc1. Soc. Supp 1., Vol. 23, No. 1, pp. 3-5. Conference on Environmental Aspects of Nonconventional Energy Resources, Denver, CO, February 29, 1976.

Campbe11, J. C. 1969. A New Look at Cooling Towers for the Power Generation Industry. Ceramic Cooling Tower Co. Cooling Tower Institute Paper No. TP66A.

Clark, A. F. July 27, 1973. Solar Ponds Extended. California University, Livermore, CA. Lawrence Livermore Laboratory Contract No. W-7405-ENG-48.

Cohn, P. D., and C. H. Bloomster. Capital Cost Models for Geothermal Power Plants. BNWL-1990, Battelle, Pacific Northwest Laboratory, Richland, WA.

Colony Development Operation. 1974. An Environmental Impact Analys is for a Shale 0 il Complex at Parachute Creek, Colorado, Vol. 1, Part 1: Plant Complex and Service Corridor. Atlantic Richfield Company, Denver, Co.

"Cooling Towers Boost Water Reuse." 1971. Environmental Science and Technology. $\underline{5}(3): 204-206$.

Crynes, B. L. 1975. "Time Schedule for Commercialization of Coal Liquefaction Processes in the United States." Energy Commun. 1(1):37-56.

Davis, George H., and Leonard A. Wood. 1974. Water Demands for Expanding Energy Development. USGS Circular 703. Reston, VA.

Dipippo, R. (Ed.). Geothermal Power Plants of Japan: A Technical Survey of Existing and Planned Installations. Report No. CATMEC/9. Brown University, Division of Engineering, Providence, RI.

Dupree, W. G., Jr., and J. A. West. 1972. United States Energy Through the Year 2000. Super intendent of Documents, U.S. Government Printing Office, Washington, DC.

El1iott, P. G. 1975. Comparison of Brine Production Methods and Conversion Processes for Geothermal Electric Power Generation. Environmental Quality Laboratory, California Institute of Technology, EQL Report No. 10.

Energy from $0 i 1$ Shale: Technical, Environmental, Economic, Legislative and Policy Aspects of an Undeveloped Resource. November 1973. Report prepared for the Subcommittee on Energy of the Committee on Science and Astronautics. U.S. House of Representatives 93rd Congress. First Session by the Science Policy Research Division, Congressional Research Service, Library of Congress. U.S. Government Printing Office, Washington, DC. 
Freeman, S. D. March 1973. Outlook for the Future. Consult. Eng.

(Barrington, IN). $40(3): 1 \overline{02-106 .}$

Gas Supply Review: Water Requirements and Availability for Coal Gasification Plants. February 15, 1975. American Gas Association, Gas Supply Committee. $\underline{3}(5): V 4261$.

Gertsch, W. D., J. Sathaye, R. Ritschard and S. Parker. August 1977. Water Requirements for Future Energy Development in the West: State Perspectives, Los Alamos Scientific Laboratory, LA-6688-MS.

Goldsmith, M. December 1976. "Geothermal Development and the Salton Sea." Energy (0xford). 1(4):367-373. December 1976.

Goldsmith, M. December 1971. Geothermal Resources in California-Potentials and Problems. Environmental Quality Laboratory Report No. 5, California Institution of Technology.

Hale, D. March 1974. "Coal Gasification Takes on a New Look." Pipeline Gas Journal. 201(3):23-26.

Hartnett, J. P. (Ed.). 1976. Alternative Energy Sources. Proc. of a Conference. Published by Academic Press, New York, NY.

Hegarty, W. P., and B. F. Moody. 1973. "Coal Gasification: Evaluating the BI-GAS SNG Process." Chemical Engineering Progress. 68:37-42.

Hi11, G. R. March 16, 1978. Technical and Economic Status of Coal and 0 il Shale Conversion. Water Acquisition for Mineral Development, Tuscon, $\bar{A} Z$.

Hittman Associates, Inc. 1974, 1975. Environmental Impacts, Efficiency and Cost of Energy Supply and End Use, Final Report. Vol. I, 1974; Vol. II, 1975. Hittman Associates, Inc., Columbia, MD.

Hotte 1, H. C., and J. B. Howard. 1971. New Energy Technology: Some Facts and Assessments. pp. 141-161. MIT Press, Cambridge, MA.

Howe, C. W., C. S. Russe 11, R. A. Young and W. J. Vough. March 1971. Future Water Demands, Report No. PB-197 877.

Hu, M. C., et a1. August 1978. Water Consumption and Costs for Various Steam Electric Power Plant Cooling Systems, EPA-600/7-78-157.

Kelley, G. M. May 1975. Cooling Tower Design and Evaluation Parameters. Power Division of ASME, 75-IPWR-9. 
Klein, M. February 3, 1977. "Outlook for Coal as an Industrial Fuel. II. Developments in Conversion Techniques. Plant Eng. (Barrington, IL). $\underline{30}(3): 73-75$.

Lane, J. A. May 1977. Consensus Forecast of U.S. Energy Supply and Demand to the Year 2000. ORNL/TM-5369.

Layton, D. W. February 1978. "Water Supply Dilemmas of Geothermal Development in the Imperial Valley of California. Water Resources Bull. $14(1): 133-143$.

Leaman, G. J., Jr., and R. E. Shlessman (Eds.). __. Phase I: The Pipeline Gas Demonstration Plant. Water Resources Report. Continental 0 il Company, Stamford, CT.

Linden, H. R. May 1972. "Outlook for Synthetic Fuels. II." Pipeline Gas Journal. 199(6):66,69,71-72,74.

Linden, H. R. 1970. U.S. Gas Demand and Supply. Technology and Use of Lignite, Grand Forks, ND, Conference 690577, May 1, 1969, Report

No. BM-IC-8471.

Loscutoff, W. V. January 1976. Preliminary Evaluation of Wet/Dry Cooling Concepts for Power Plants. BNWL-1969. Battelle, Pacific Northwest Laboratory, Richland, WA.

Manaham, S. E. 1975. $\mathrm{H}_{2} 0$ : The Limiting Reactant in the Energy Equation. Am. Chem. Soc., Div. Environ. Chem., Prepr., 15(1):198-200. 169th ACS National Meeting, Philadelphia, PA.

McKee, J. M., and S. K. Kuncha 1. October 1976. Energy and Water Requirements for an 0 il Shale Plant Based on Paraho Processes. Colorado School of Mines, Vol. 71, No. 4, pp. 49-64. 9th 0 il Shale Symposium, Golden, Co., Apri1 29, 1976.

Miliaras, E. S. 1974. Power Plants with Air-Cooled Condensing Systems. MIT Press, Cambridge, MA.

Milios, P. June 1975. "Water Reuse at a Coal Gasification Plant." Chem. Eng. Prog. 71(6):99-104.

01son, G. K., and B. Breinde1. July 13, 1976. Electric Conversion Economics. Susanville Geothermal Energy Project. Workshop Proceedings Final Technical Report. pp. XI.1 - XI.13.

Pines, H. S., W. L. Pope, M. A. Green, P. A. Doyle, L. F. Silvester, and R. L. Fulton. July 25, 1978. Thermodynamic and Cost Benefits of a Floating Cooling Geothermal Binary Cycle Power Plant at HEBER, CA. Geothermal Resources Councit Meeting, HILO, HI. 
Proceedings of the 1978 D.0.E Workshop on System Studies for Central Solar Thermal Electric, March 27-30, 1978, Houston, Texas. CONF-780383.

Radian Corporation. May 1977. Investigation of the Potential for Utilization of Saline Ground Water in Energy - Related Processes. Radian Corp., Austin, TX.

Russe11, J. L., Jr. 1977. Fixed Mirror Solar Concentrator for Central Station Generation. Proc. Am. Power Conf., Vol. 39, pp. 622-634. CoNF-770403. 39th Annual Meeting of the American Power Conference, April 18, 1977.

Seay, J. G. September 1976. "Role of Alternate Fuels in the U.S. Energy Mix." Pipeline Ind. $45(3): 29-32$.

Shaffer, C. J. $\quad$ Floating Power Optimization Studies for the Cooling System of a Geothermal Power Plant. EG\&G, Idaho, Inc., Idaho Falls, ID.

Smith, K., J. Weyant and J. Holdren. July 1975. Evaluation of Conventional Power Systems. ERG75-5, UC Berkeley, CA.

Solar Thermal Power Systems Program Summary. December 1978. DOE/ET0078.

Starr, C. 1976. Role of Advanced Energy Systems. 2nd Topical Meeting on the Technology of Controlled Nuclear Fusion, September 21, 1976. CONF-760935, p. 1, pp. 7-19.

Stickley, R. A., and R. J. Zoschack. 1975. Central Receiver Solar Power Plant in a Hybrid Mode of Operation. AIAA/AAS (Am. Astronaut. Soc.), Solar Energy for Earth Conference, Los Angeles, CA, April 21-24, 1975. Published by AIAA, New York, NY. Paper 75-624.

Surface, M. 0. September 1977. Power Engineering. 81:42-50.

Susanville Geothermal Energy Project. 1976. Workshop Proceedings, Final Technical Report, July 13, 1976. City of Susanville. Report

No. SAN-1077-4.

Turner, R. H. 1976. Economic Optimization of the Energy Transport Component of a Large Distributed Collector Solar Power Plant. Intersoc. Energy Convers. Eng. Conf., 11th Proc., State Line, NV, September 12-17, 1976. Vol. 2, SAE Paper 769216, pp. 1239-1243. Published by AIChE, New York, NY.

Willis, D. J. June 1978. "Effect of the Broadlands Geothermal Power Scheme on the Waikato River." Geotherm. Energy. 6(6):25-34.

Young, Robert A., and S. Lee Gray. March 1972. Economic Value of Water: Concepts and Empirical Estimates. NTIS, No. PB-210-356. 
APPENDIX A

SECTOR CONSUMPTION OF ENERGY FUELS 
APPENDIX A

SECTOR CONSUMPTION OF ENERGY FUELS (BtU $\times 1015)$

TABLE A.1. Low Growth/Low Coal, Year 1985

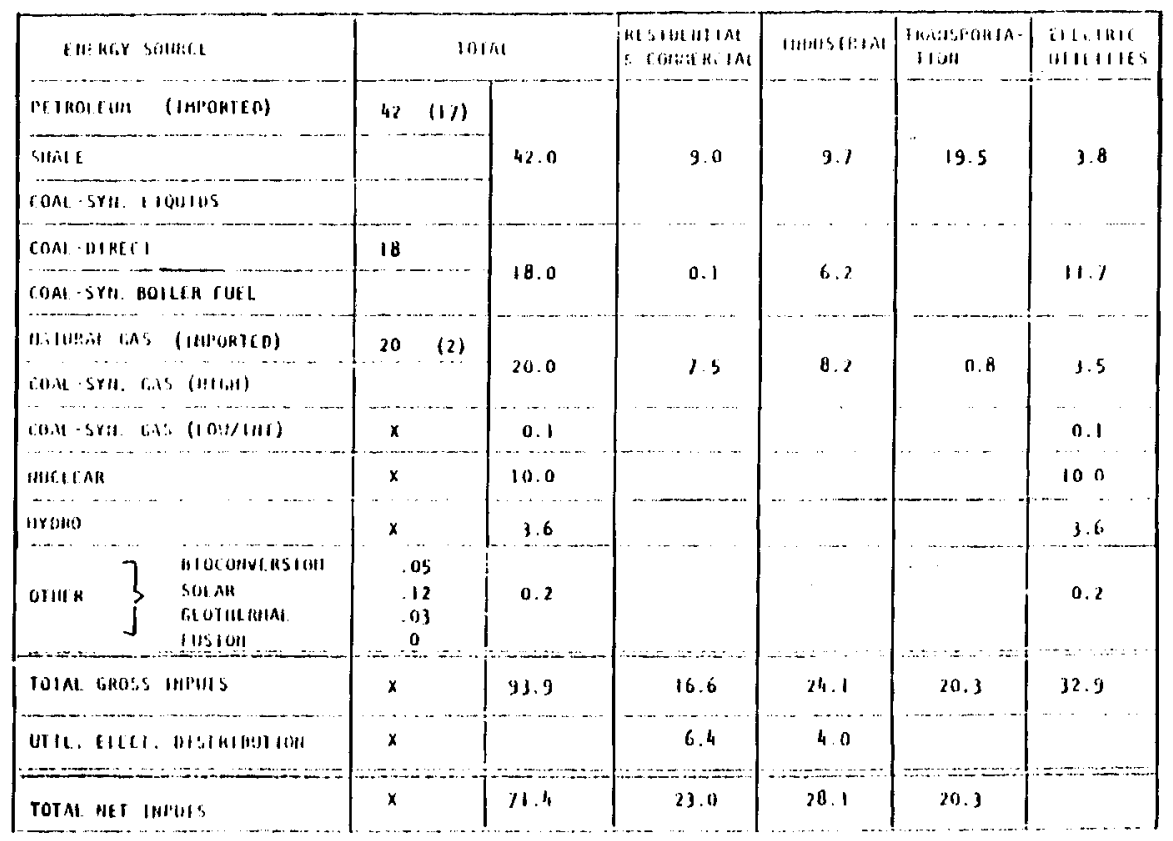

TABLE A.2. Low Growth/Low Coal, Year 2000

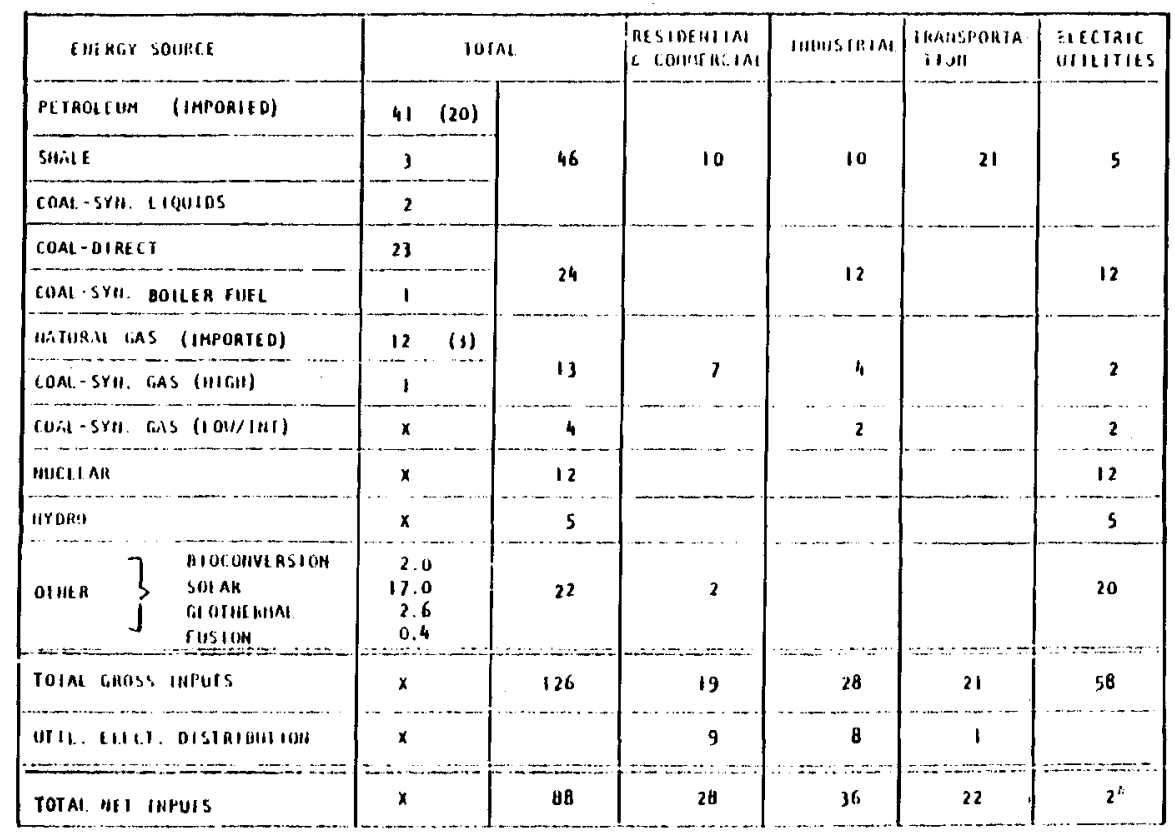

Huse of pewer plame vaste drat 
TABLE A.3. Low Growth/Low Coal, Year 2025

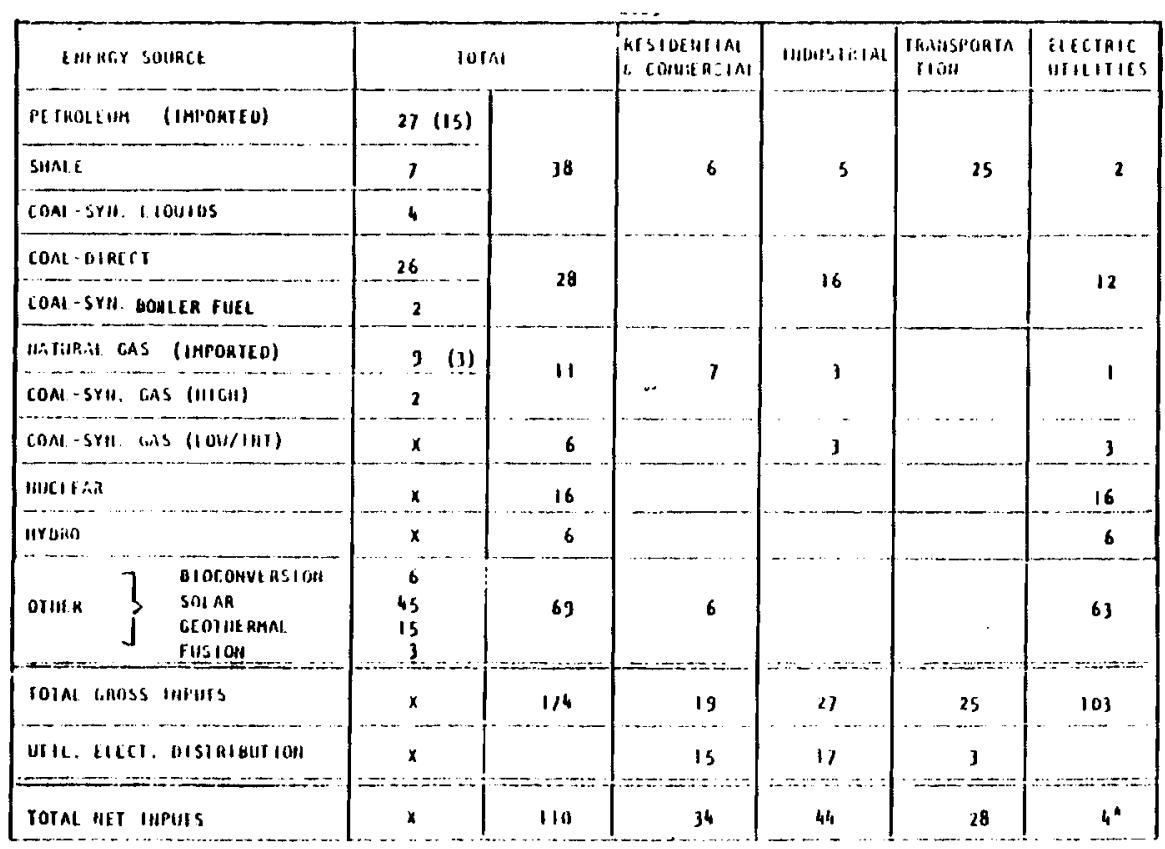

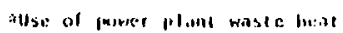

TABLE A.4. Intermediate Growth/Populist, Year 1985

\begin{tabular}{|c|c|c|c|c|c|c|}
\hline EHE HEY SOUATCE & $\begin{array}{r}10 \\
\end{array}$ & it & 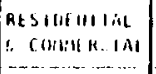 & Imoust:ist. & 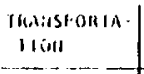 & 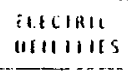 \\
\hline DETROLZUM (IMPOATED) & $41.6(9)$ & & & & & \\
\hline SHILLE & & 41.8 & 10.2 & .6 .7 & 22.1 & 2.8 \\
\hline COAL-SYII. I. IQUIOS & 0.2 & & & & & \\
\hline COAL-DIRECT & 29.0 & 70 & 01 & 1) 5 & & \\
\hline COAI-SYM BOILER FUEL & 0.1 & 4. & 0.1 & 12.3 & & 16.3 \\
\hline HIJUFAL CAS (IMPORIED) & $19.0 \quad$ (1) & 190 & & & & \\
\hline Co.tL-sYat. Gis (IIIGH) & & 13.0 & 0.0 & h. & 0.8 & 3.3 \\
\hline cont-5YII. Gins (1.0W/IIII) & $x$ & 0.3 & & 0.1 & & \\
\hline HuCI fan & $\underline{x}$ & 11.5 & & & & \\
\hline HYDRo & $x$ & 3.6 & & & & 3.6 \\
\hline OTIIER $\left\{\begin{array}{l}\text { GIOCOHUERSION } \\
\text { SOLAR } \\
\text { GEOTHIE RHAL } \\
\text { FUSION }\end{array}\right.$ & $\begin{array}{l}.05 \\
.12 \\
.03 \\
0 \\
0\end{array}$ & 0.2 & & & 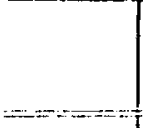 & $:=x=4=$ \\
\hline TOIAL GRUSS IHPUIS & $x$ & 105.5 & 18.3 & 25.2 & 22.9 & 39.1 \\
\hline UTIL. EIECT. DISTRIOUTIOII & $x$ & & 1.2 & 4.9 & 0.3 & \\
\hline TOTAL MET INPUTS & $x$ & 78.8 & 25.5 & 30.1 & 23.2 & \\
\hline
\end{tabular}


TABLE A.5. Intermediate Growth/Populist, Year 2000

\begin{tabular}{|c|c|c|c|c|c|c|}
\hline EHE ke, souncl & 10 & & 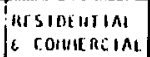 & MHEUSIPIAL & $\begin{array}{l}\text { Transporin- } \\
\text { Tläl }\end{array}$ & \begin{tabular}{|l} 
Elcifiric \\
UrHIIIIIS
\end{tabular} \\
\hline PE JAOLSUM (IMPORIEO) & $29(9)$ & \multirow{3}{*}{42} & \multirow{3}{*}{10} & \multirow{3}{*}{3} & \multirow{3}{*}{ 27 } & \multirow{3}{*}{2} \\
\hline SHALI & 1 & & & & & \\
\hline COAL - SrM. L LQU1OSS & 6 & & & & & \\
\hline COAL - OIRECT & 34 & \multirow{2}{*}{37} & & \multirow{2}{*}{18} & & \multirow{2}{*}{19} \\
\hline COAL - SYH. BOILER FUEL & 了 & & & & & \\
\hline 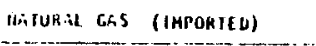 & 9 (1) & \multirow{2}{*}{11} & \multirow{2}{*}{8} & \multirow{2}{*}{2} & & \multirow{2}{*}{1} \\
\hline COAL-5YII. CAS (HICII) & 2 & & & & & \\
\hline COAL-SVII. GAS (LGW/HII) & $x$ & 12 & & 5 & & 7 \\
\hline HACL:AR & $x$ & 12 & & & & 12 \\
\hline 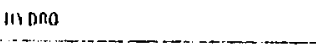 & $x$ & 5 & & & & 5 \\
\hline oHiten $\begin{array}{l}\text { BLOCOHVERSION } \\
\text { SOIAR } \\
\text { GeOIILLHAL }\end{array}$ & $\begin{array}{r}2.6 \\
16.6 \\
3.3 \\
-5.9 \\
\end{array}$ & 23 & 4 & $x=-x=-1$ & 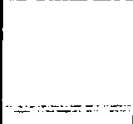 & $\begin{array}{l}19 \\
=-\square\end{array}$ \\
\hline TOIAL. gross IHPUS & $x$ & 142 & 22 & 28 & 27 & 65 \\
\hline UICL. EIECT, DISIMIUUI IUH & $\begin{array}{l}x \\
==-\end{array}$ & & 11 & 8 & 2 & $\Rightarrow$ \\
\hline TOTAL. HEI IMPUIS & $x$ & 101 & 33 & 36 & 29 & $3^{*}$ \\
\hline
\end{tabular}

AUse of power plant waste licat

TABLE A.6. Intermediate Growth/Popu Tist, Year 2025

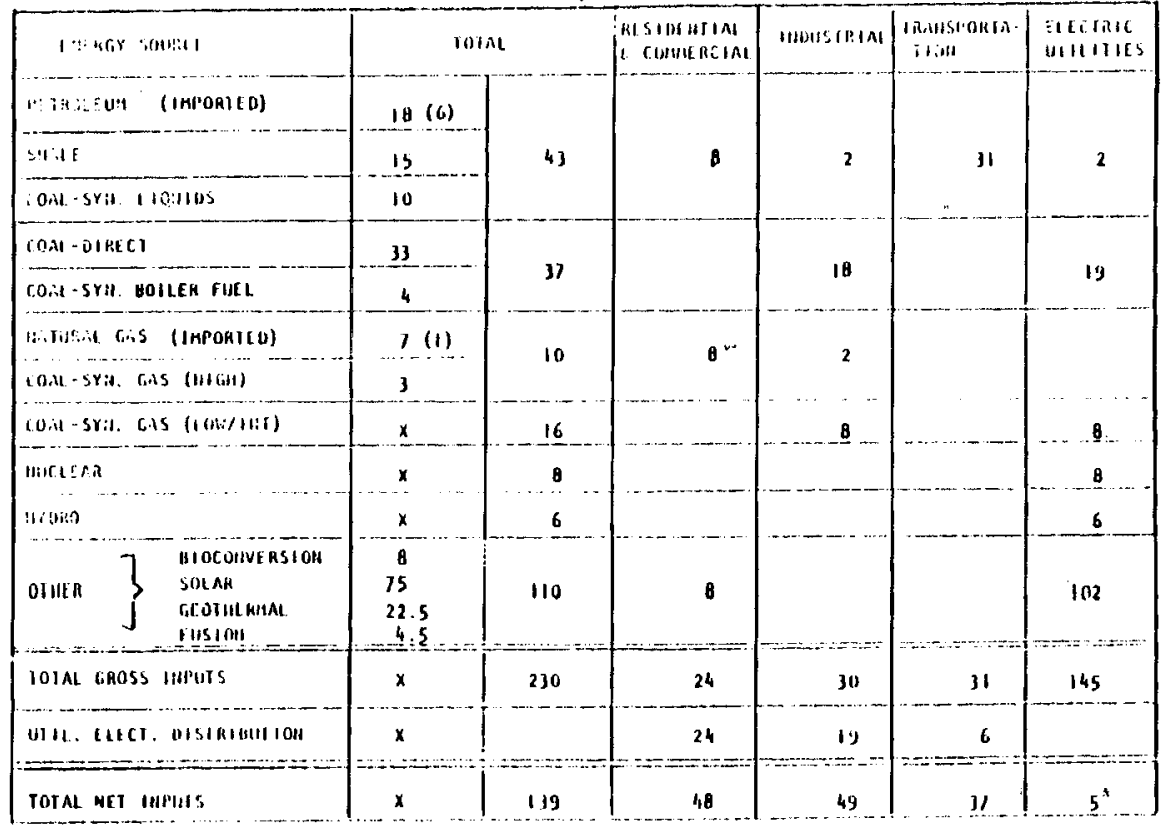

atye of power plant wasto heat 
TABLE A.7. Intermediate Growth/Establishment, Year 1985

\begin{tabular}{|c|c|c|c|c|c|c|}
\hline EHERTYY SOUHLE & InI. & & $\begin{array}{l}R L S I D C H I I A L \\
G \text { CORUIL } A: I A \mid\end{array}$ & IIIOUSIKIAL & $\begin{array}{l}\text { IRI:ISTOATA- } \\
\text { IIJII }\end{array}$ & $\begin{array}{l}\text { ELECIRIE } \\
\text { UTHIIIES }\end{array}$ \\
\hline PETROLEUM (IMPDRTEO) & $48.0(18)$ & \multirow{3}{*}{48.2} & \multirow{3}{*}{10.5} & \multirow{3}{*}{8.6} & \multirow{3}{*}{24.7} & \multirow{3}{*}{4.4} \\
\hline Sulite & & & & & & \\
\hline COAL-SYII. LIQUIUS & 0.2 & & & & & \\
\hline COAL + DIAECT & 27.0 & \multirow{2}{*}{27.1} & \multirow{2}{*}{0.1} & \multirow{2}{*}{11.0} & & \multirow{2}{*}{16.0} \\
\hline COAL-SVIA. BOILER FUEL & 0.1 & & & & & \\
\hline MITUREL CAS (IHPORIEO) & $20.1(1.5)$ & \multirow{2}{*}{20.4} & \multirow{2}{*}{8.2} & \multirow[b]{2}{*}{7.4} & \multirow[b]{2}{*}{0.8} & \multirow[b]{2}{*}{4.0} \\
\hline COAL-SYII, Gis (IIIGII) & 0.3 & & & & & \\
\hline COAL-SYII. CIS (LOH/HHT) & $x$ & & & & & \\
\hline HUCI ISAR & $x$ & 12.0 & & & & 12.0 \\
\hline IIYORO & $x$ & 3.6 & & & & 3.6 \\
\hline OTHEK $\int^{7} \begin{array}{l}\text { BIOCOIIVERSIOH } \\
\text { SOLAR } \\
\text { GEOTIIEKMAL } \\
\text { FUSIOH }\end{array}$ & $\begin{array}{l}.05 \\
.12 \\
.03 \\
0.0\end{array}$ & 0.2 & $:=$ & $-\because:=--1$ & & $\underline{y}=$ \\
\hline TOHAi GNUSS IHIDUS & $x$ & 111.5 & 10.8 & 21.0 & 25.5 & 40.2 \\
\hline 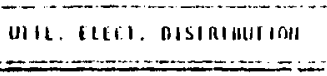 & $x$ & & 9.0 & 4.7 & 0.1 & \\
\hline TOTAL mer IIIPUTS & $x$ & 84.1 & 26.8 & 31.7 & 25.6 & \\
\hline
\end{tabular}

TABLE A.8. Intermediate Growth/Establishment, Year 2000

\begin{tabular}{|c|c|c|c|c|c|c|}
\hline Chencr sominet & 1014 & & $\begin{array}{l}\text { WI SHOEHTIAI } \\
\text { C COHHE RCIA1 }\end{array}$ & 1110)1ST:1AC & 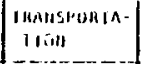 & $\begin{array}{l}\text { ELCORIC } \\
\text { WIULIJIES }\end{array}$ \\
\hline PLIROLEUM (IHPORTEO) & $38 \quad(15)$ & & & & & \\
\hline $\sin 1 E$ & B & 53 & 10 & $\mathbf{\theta}$ & 29 & 6 \\
\hline COAL-SYH. L IQUIOS & 7 & & & & & \\
\hline COAL-DIACCI & 32 & & & & & \\
\hline COAL - SYM. BOILEA FUEL & 3 & 35 & & 16 & & 19 \\
\hline $\begin{array}{l}\text { WATURAL CAS (IMHORIEO) } \\
\text { CONL-SYH. GAS (IIITII) }\end{array}$ & $11 \quad(2)$ & 15 & - & $\mathbf{J}$ & & 4 \\
\hline COAL-SYH. GAS $(10 W / W H T)$ & $x$ & 10 & & 4 & & 6 \\
\hline micleAR & $x$ & 15 & & & & 15 \\
\hline $\begin{array}{l}\text { lirono } \\
\text {-... }\end{array}$ & $x$ & 5 & & & & 5 \\
\hline OTIICR $\left\{\begin{array}{l}\text { UIOCOHVEASION } \\
\text { SOLAN } \\
\text { GEOTHLAHAL } \\
\text { FUSION }\end{array}\right.$ & $\begin{array}{r}2.6 \\
18.6 \\
3.3 \\
\quad .5 \\
\end{array}$ & 25 & $=\ldots$ & $\because \therefore z_{1}=-1$ & $\therefore:=1=$ & $\begin{array}{c}19 \\
=-2=-\infty\end{array}$ \\
\hline TOTAL GRUSS IHEUIS & $\underline{x}$ & 158 & 24 & 31 & 23 & 14 \\
\hline UTHL. ELEIT. OISIRIBUTIOH & $x$ & $=--=1$ & 12 & 10 & 3 & $=-$ \\
\hline TOTAL NEI INPUIS & $x$ & 112 & 36 & 4 & 32 & $3^{\prime \prime}$ \\
\hline
\end{tabular}

suse of power pilut waste luedt 
TABLE A.9. Intermediate Growth/Establ ishment, Year 2025

\begin{tabular}{|c|c|c|c|c|c|c|}
\hline G HERCY SOUREC & IOI & & $\left|\begin{array}{l}\text { RESTOERYIAL } \\
\text { E COHAE RCIAI }\end{array}\right|$ & IUUUSGRIMI & $\begin{array}{l}\text { IR.MISPOATA- } \\
\text { IISHI }\end{array}$ & $\begin{array}{l}\text { ELECIIIIC } \\
\text { UIILIIIES }\end{array}$ \\
\hline PETROLEUA (IMPOATED) & $24 \quad(12)$ & \multirow{3}{*}{53} & \multirow{3}{*}{10} & \multirow{3}{*}{6} & \multirow{3}{*}{34} & \multirow{3}{*}{3} \\
\hline SIthLE & 17 & & & & & \\
\hline COAL-SYH. LIQUIDS & 12 & & & & & \\
\hline COAI-DIEECT & 30 & \multirow{2}{*}{34} & & \multirow{2}{*}{17} & & \multirow{2}{*}{17} \\
\hline COAL-SYII. BOILEN FUEL & 4 & & & & & \\
\hline BATURAL CFS (IMPORIEO) & $8 \quad(2)$ & \multirow[b]{2}{*}{13} & \multirow[b]{2}{*}{8} & \multirow[b]{2}{*}{3} & & \multirow[b]{2}{*}{2} \\
\hline COAL-SYH. lons (IIISIH) & 5 & & & & & \\
\hline COML-SYII. CANS (1OH/IHI) & $x$ & 14 & & 7 & & 7 \\
\hline mLLLAR & $x$ & 25 & & & & 25 \\
\hline irpono & $x$ & 6 & & & & 6 \\
\hline OTHEA $\left\{\begin{array}{l}\text { GOCOLIVE HSION } \\
\text { SOLAH } \\
\text { GOTIIIRAML }\end{array}\right.$ & $\begin{array}{r}7.4 \\
78.0 \\
24.0 \\
4.6 \\
-2.6\end{array}$ & 115 & 10 & & & $\begin{array}{r}105 \\
-\end{array}$ \\
\hline TOTAL GROSS IHAPUSS & $x$ & 260 & 28 & 33 & 34 & 165 \\
\hline 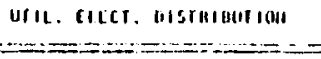 & $x$ & & 26 & 23 & 7 & $-1=-1$ \\
\hline TOTAL NET IMI'UIS & $x$ & 151 & 54 & 56 & 41 & $6^{*}$ \\
\hline
\end{tabular}

nileo or "power plant waste licale

\section{TABLE A.10. High Growth/High Coal, Year 1985}

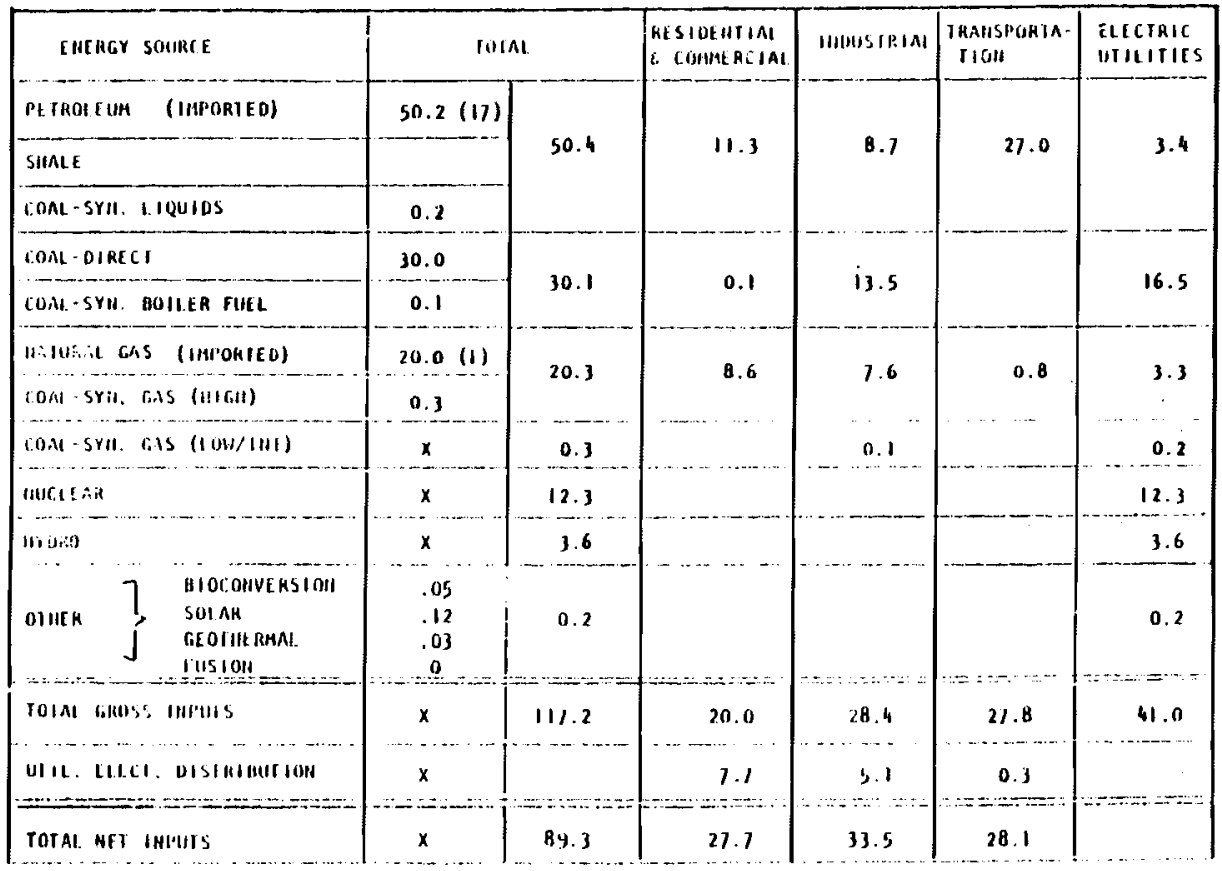


TABLE A.11. High Growth/High Coal, Year 2000

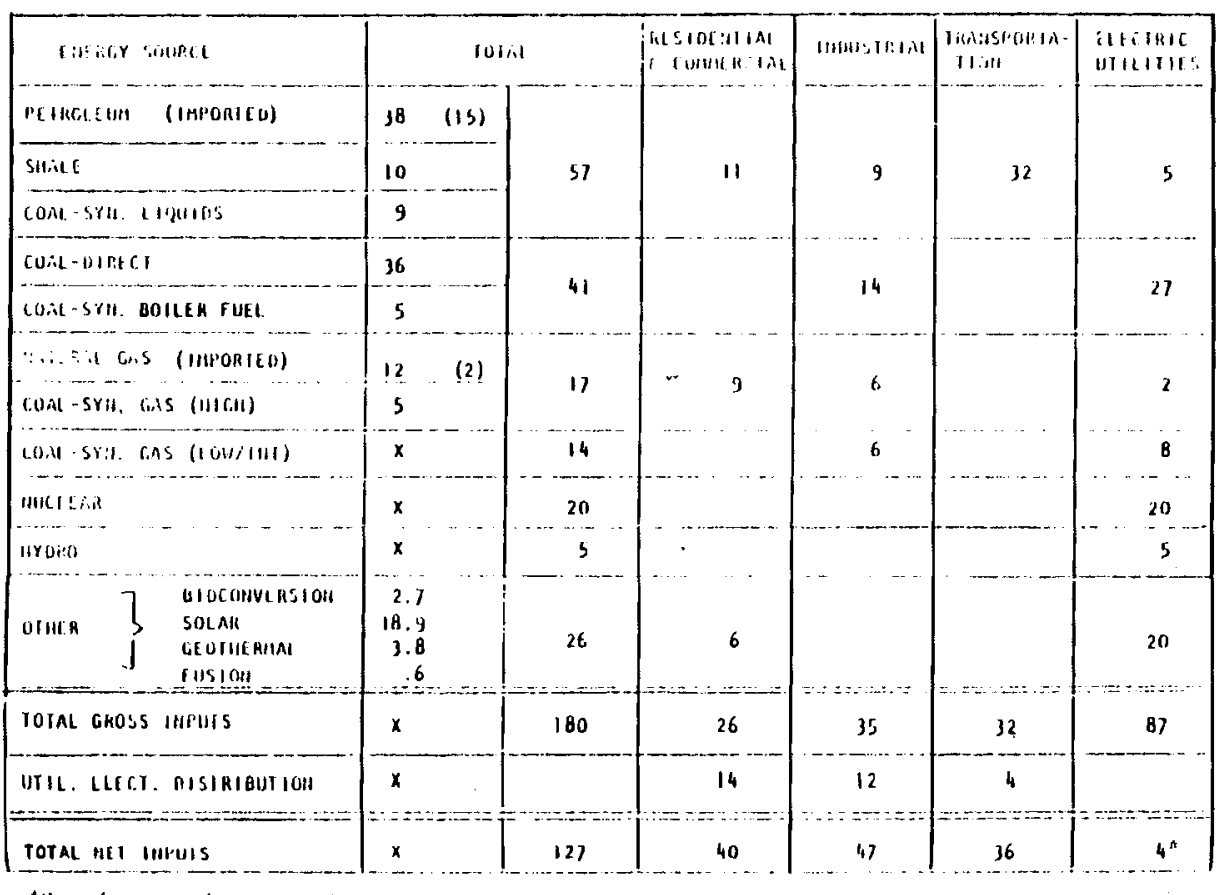

TABLE A.12. High Growth/High Coal, Year 2025

\begin{tabular}{|c|c|c|c|c|c|c|}
\hline EM. IIGY SUHASE & $101 n$ & & $\begin{array}{l}\text { KES SOCUTIML } \\
\text { i. COMUEREIAL }\end{array}$ & HHotrint & $\begin{array}{l}\text { I Heisponta- } \\
\text { rian }\end{array}$ & 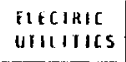 \\
\hline P'TIROIIUM (IHPORIEO) & 21 (13) & & 1. & & & \\
\hline SHail E & 20 & 62 & 12 & 10 & 35 & 5 \\
\hline COAL-SYH. LIQHIOS & 15 & & & & & \\
\hline COAI. - DIRCCT & 34 & & & & & \\
\hline IUAL-SYII. BOILEA FUEL & B & 42 & & 13 & & 29 \\
\hline HNIUPR CAS (IMPQATED) & $9 \quad(2)$ & & & & & \\
\hline COM-5YH. COAS (IIIGII) & B & 17 & 11 & 4 & & 2 \\
\hline COMI - SYH. CAS (1ON/IHI) & $\underline{x}$ & 22 & & 8 & & 14 \\
\hline MUCLIAH & $x$ & 38 & & & & 38 \\
\hline "IYнно & $x$ & 6 & & & & 6 \\
\hline OTIIER $\left\{\begin{array}{l}\text { BLOCUHVERSION } \\
\text { SOLAII } \\
\text { CEOTIERHAI. }\end{array}\right.$ & $\begin{array}{r}9 \\
90 \\
24 \\
5\end{array}$ & 128 & 川 & & & $=$ \\
\hline TOIML GHUSS IHWUIS & $x$ & 315 & 34 & 35 & 35 & 211 \\
\hline 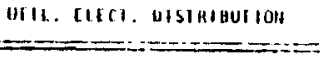 & $\stackrel{x}{x=}=$ & $=$ & $2 y$ & $=-31$ & $=-12$ & 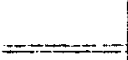 \\
\hline TOTAL NET IRPUTS & $x$ & 184 & 63 & 66 & 47 & $B^{*}$ \\
\hline
\end{tabular}

tise of friws plint waste lieal 
APPENDIX B 
APPENDIX B

ASSUMPTIONS FOR ENERGY PROJECTION ANALYSIS

GENERAL ASSUMPTIONS

- 1 barrel of oil yields $5.8 \times 10^{6} \mathrm{Btu}(\mathrm{a})$

- 1 kilowatt-hr is equivalent to $3412 \mathrm{Btu}(\mathrm{a})$

- 1 cubic foot of synthetic gas yields $900 \mathrm{Btu}(\mathrm{a})$

SOLAR ENERGY ASSUMPTIONS

- Fuel displaced is pased on 10,000 Btu input for 1 kilowatt-hr output (34\% efficiency) (b)

- Capacity factor equals 0.6 in 1985, 0.7 thereafter (Bereny, 1977)

- Percentage of total solar power due to central tower plants based on Table 14 .

- Percentage of total solar power used for electricity generation based on Table 13.

GEOTHERMAL ENERGY ASSUMPTIONS

- Fue 1 displaced is pased on 10,000 Btu input for 1 kilowatt-hr output ( $34 \%$ efficiency) $(b)$

- Capacity factor equals 0.78 (Mathew, 1973).

- Percentage of total power used for electricity generation based on Table 12 .

(a) Values from U.S. Department of the Interior, Westwide......4/75.

(b) This is analogous to the method used for hydro power energy supply figures. 


\section{DISTRIBUTION}

No. of

Copies

OFFSITE

U.S. Department of Energy

A. A. Churm

Chicago Patent Group

9800 South Cass Avenue

Argonne, IL 60439

U.S. Department of Energy

Office of Assistant General

Counse 1 for Patents

Washington, DC 20545

27 DOE Technical Information Center

10 U.S. Department of Energy

I. Helms

Division of Advanced Systems and Materials Production

Washington, DC 20545

U.S. Department of Energy

W. F. Savage

Division of Advanced Systems and Materials Production

Washington, DC 20545

U.S. Department of Energy

N. Goldenberg

Director, Division of Advanced Systems and Materials Production Washington, DC 20545

U.S. Department of Energy

C. Grua

Environmental Control Technology Office of Environmental

Compli ance Overview

Washington, DC 20545
No. of

Copies

U.S. Department of Energy

W. E. Mott

Director, Environmental Control

Techno logy

Office of Environmental

Compli ance Overview

Washington, DC 20545

U.S. Department of Energy

J. M. Deutch

Director, Office of Energy

Research

Washington, DC 20545

Allied Chemical Company

B. R. Dickey

550 2nd Street

Idaho Falls, ID 83401

Allis-Chalmers Power Systems, Inc.

J. S. Joyce

1135 South 70th Street

West Allis, WI 53214

Aluminum Company of America

E. T. Wanderer

Alcoa Technical Center

Alcoa Center, PA 15069

American Electric Power Service Corporation

H. J. Janzon

2 Broadway

New York, NY 10004

American Electric Power Service Corporation

C. Swenson

2 Broadway

New York, NY 10004

Aqua-Chem

R. M. Ahlgren

P.0. Box 421

Milwaukee, WI 53201 
No. of

\section{Copies}

Arizona Public Service Co.

W. E. Campbe 11

P.0. Box 21666

Phoen ix, AZ 85036

Arizona Public Service Co.

$T$. Woods

2121 W. Cheryl Drive

Phoenix, AZ 85021

Babcock \& Wilcox

M. W. Peterson

Fossil Power Division

20 South Van Buren

Barberton, $\mathrm{OH} 44203$

Baltimore Aircoil Co., Inc.

E. Schinner

P.0. Box 7322

Baltimore, MD 21227

Baltimore Gas \& Electric Co.

G. C. Cree 1

Gas \& Electric Building

Baltimore, MD 21203

Batte lle-Geneva

J. P. Budliger

7 Route De Drizi

1227 Geneva, SWITZERLAND

Bechte 1 Corporation

$P$. Leung

P.0. Box 60860

Terminal Annex

Los Anqeles, CA 90060

Bechtel Corporation

G. R. Ret $i$

P.0. Box 3965

San Francisco, CA 94119

R. W. Beck and Associates

J. P. Rossie

400 Prudential Plaza

Denver, CO 80202
No. of

Copies

Betz Environmental Enqineers

J. Soost

One Plymouth Meeting Mall

Plymouth Meeting, PA 19462

Black, Crow and Eidsness, Inc.

C. G. Thompson

807 South MCDonough

Montogomery, AL 35104

Black Hills Power and Light Company

B. Westre

P.0. Box 1400

Rapid City, SD 57701

Boeing Aerospace Division

D. Gilbert (M.S. 2ROO)

P.0. Box 3999

Seattle, WA 98124

Bonneville Power Administration

E. H. Hall

1002 N.E. Holladay Street

Box 3621

Portland, OR 97208

Burns and Roe, Inc.

700 Kinder Kamack Rd.

Orade 1, NY 07649

California Energy Commission

C. Webb

1111 Howe Avenue

Sacramento, CA 95825

California State Enerqy Resources Conservation and Development Commiss ion

L. E. Stamets

1111 Howe Avenue

Sacramento, CA 95825

Carolina Power \& Light Co. J. Sell

336 Fayettesville Street

Raleigh, NC 27602 
No. of

Copies

Catalytic Construction Corp.

J. Morse

P.0. Box 15232

Char lotte, NC 28210

Ceramic Cooling Tower Co.

P. A. Frohwerk

P.0. Box 425

Fort Worth, TX 76101

Chicago Bridge and Iron Company

M. Husa in

800 Jovie Boulevard

Oak Park, IL 60521

Combustion Engineering Lummus Engineer ing Company

R. J. Croke

1515 Broad St

Bloomingfield, NJ 07003

Columbus and Southern Ohio Electric Co.

L. W. Meridith

Genera 1 Manager, Generation Department

215 North Front Street

Columbus, $\mathrm{OH} 43215$

Combustion Enqineering

H. H. Osborn

Air Preheater Company

Wellsville, NY 14895

Commonwea Ith Edison

R. H. Holyoak

One First Plaza

P.0. Box 767

Chicago, IL 60690

Consolidated Edison Co. of New York, Inc.

W. A. Messner

4 Irving Place

New York, NY 10003
No. of

Copies

Consolidated Edison Co. of New York, Inc.

C. L. Newman

4 Irving Place

New York, NY 10003

Cooling System, Inc.

C. Mitche 1

8490 Avenue 296

Visalia, CA 93877

Corne 11 University

F. K. Moore

Ithaca, NY 14850

Curtiss-Wright Corporation

R. J. Haberski

One Passaic Street

Wood Ridge, NJ 07075

Dames \& Moore

L. Craton

Suite 1000

1100 Glendon Avenue

Los Angeles, CA 90024

Dames \& Moore

P. Gott 1 ieb

Suite 1000

$1100 \mathrm{Glendon}$ Avenue

Los Angeles, CA 90024

Delmarva Power \& Light

F. Cook

$800 \mathrm{King}$ Street

Wilmington, DE 19801

Dow Chemical Company

E. Wagener

2800 Mitche 11 Drive

Walnut Creek, CA 94598

Duke Power Company

S. K. Blackley

P.0. Box 2178

Charlotte, NC 28201 
Duquesne Light Co.

J. Latshaw

4356 th Avenue

Pittsburgh, PA 15219

Dynatech Company

E. Guyer

99 Erie Street

Cambridge, MA 02139

Ecodyne

J. Slotnik

607 First Street, S.W.

Massillon, $\mathrm{OH} 44646$

Ecodyne Cooling Products Co.

J. K. Swindt

P.0. Box 1267

Santa Rosa, CA 95403

Ecodyne Cooling Products

K. D. Whitehead

P.0. Box 1267

Santa Rosa, CA 95403

Electric Power Research Institute

J. Maulbetsch

3412 Hilview Avenue

P.0. Box 10412

Palo Alto, CA 94304

Empire State Electric Enerqy Research Corp.

L. Geller

1271 Avenue of the Americas

New York, NY 10020

Environmental Protection Agency

T. G. Brna (MD-61)

IERL/RTP

Research Trianqle Park, NC 27711

Environmental Protection Aqency

A. Galley (WH-552)

401 M. Street SW

Washington, DC 20460
Environmental Protection Agency

M. Maxwe T1 (MD-61)

IERL/RTP

Research Triangle Park, NC 27711

Environmental Protection Agency

F. H. Rainwater

Pac if ic Northwest Water Laboratory

200 S.W. 35th Street

Corvatils, OR 97330

Environmental Protection Agency

F. A. Roberts

200 S.W. 35th Street

Corvallis, OR 97330

Environmental Sciences and Services

W. G. Hoydysh

150 East 73rd Street

New York, NY 10021

Environmental Systems Corporation

K. Wilber

P.0. Box 2525

Knoxville, TN 37901

ERG Incorporated

G. M. Benson

Lowe 11 57th Street

0ak land, CA 94608

Exxon Research Center

J. G. Stevens

B ldg. 1, Rm. 2048

P. 0. Box 8

Linden, NJ 07036

Federal Power Commission

E. Sligh

825 N. Capitol Street

Washington, DC 20426

Florida Power \& Light Co.

C. Henderson

9250 W. Flagler Street

Miami, FL 33174 
No. of

Copies

Foster Whee ler Development Corporation

R. J. Zoschak

Technical Director, Applied Thermodynamics Research

12 Peach Tree Hill Road

Livingston, NJ 07039

Foster Whee Ter Energy Corporation

E. L. Damon

110 S. Orange Avenue

Livingston, NJ 07039

Foster Whee Ter Energy Corporation

W. H. Fisher, Jr.

Project Manager

110 S. Orange Avenue

Livingston, NJ 07039

Foundation Sciences, Inc.

L. E. Wilkinson

Cascade Building

Portland, OR 97204

Franklin Institute

A. M. Rubin

Twent ieth \& Parkway

Philadelphia, PA 19103

Frick Company

J. Bibroff

15302 El Mar Lane

Kerman, CA 93630

GEA Airexchangers, Inc.

B. Davis

P.0. Box 1377

Thomasville, GA 31792

GEA Power Cooling Systems, Inc.

G. Hesse

P.0. Box 81608

San Diego, CA 92138

Genera 1 Atomic Company

A. C. Eutberg

P.0. Box 81608

San Diego, CA 92138
No. of

Copies

General Atomic Company

H. P. Fay

P.0. Box 81608

San Diego, CA 92138

General Electric Co.

E. H. Miller

Large Steam Turbine Division

300 Nott Street

Schenectady, NY 12301

General Motors Corp.

R. K. Shah

Harrison Radiator Division

Lockport, NY 14094

Georgia Power Co.

T. E. Byer ley

P.0. Box 4545

Atlanta, GA 30302

Gilbert Associates, Inc.

J. F. Sebald

525 Lancaster Avenue

Reading, PA 19603

Heat Transfer Research Inc.

J. E. Taborek

1000 S. Fremont Avenue

A Thambra, CA 91802

Hudson Products

M. W. Larinoff

6855 Horwin Drive

Houston, TX 77036

Hudson Products

E. C. Smith

6855 Horwin Drive

P.0. Box 36100

Houston, TX 77036

H2M Corporation

H. D. Freudentha 1

500 Broad Hollow Road

Meiville, NY 11746 
No. of

Copies

Ingerso 11-R and

W. R. Scott, Jr.

Phillipsburg, NJ 08865

Italimpiant $i-S o c$ ieta Italiana Impiant $i$ p.a.

C. Rocco

Piazza, Piccapietra 9

18121 Genoe, ITALY

Los Alamos Scient ific Laboratory

D. Abbey

S-2, MS 606

Los Alamos, NM 87545

Los Angeles Department of Water and Power

J. L. Mulloy

111 N. Hope Street

Los Angeles, CA 90012

Louisiana Power \& Light Co.

D. L. Aswe 11

142 Delaronde Street

New Or leans, LA 70174

The Char les T. Ma in Co.

E. S. Miliaras

Southeast Tower

Prudential Center

Boston, MA 02199

Mar ley

C. A. Baird

12 S. 12 th Street

Philadelphia, PA 19107

Mar ley

J. D. Holmberg

5800 Fox Ridge Drive

Mission, KS 66202

Mar ley

R. Landon

5800 Fox Ridge Drive

Mission, KS 66202
No. of

Copies

Martin Marietta Laboratories

L. Bongers

1450 South Rolling Road

Baltimore, MD 21227

Massachusetts Institute of Technology

L. R. Glicksman

77 Massachusetts Avenue

Cambridge, MA 02139

Massachusetts Institute of Technology

M. W. Golay

77 Massachusetts Avenue

Cambridge, MA 02139

Massachusetts Institute of Technology

R. Har leman

Department of Civil Engineering

77 Massachusetts Avenue

Cambridge, MA 02139

McDonne 11 Douglas Astronautics Company

W. H. P. Drummond

5301 Balsa Avenue

Huntington Beach, CA 92647

McDonnell Douglas Astronautics

Company

S. O'Hare

$5301 \mathrm{Ba}$ lsa Avenue

Huntington Beach, CA 92647

Minnesota Power Cooperative, Inc.

L. A. Hillier

Box 1318

Grand Forks, ND 58201

R. D. Mitche 11

Consulting Engineer

4531 East Best Road, SEDC

Larkspur, CO 80118 
No. of

Copies

Montana Power Co.

R. Hof acher

40 E. Broadway

Butte, MT 59701

Niagara Blower

W. Kals

405 Lexington Avenue

New York, NY 10017

Northeast Utilities

R. H. Meyer

P.0. Box 270

Hartford, CT 06101

Northern States Power Co.

R. Stansfield

414 Nicollet Mal1

Minneapolis, MN 55401

N.U.S. Corporation

S. Lefton

2 Palo Alto Square (Suite 624)

Palo Alto, CA 94304

Oak Ridge National Laboratory

J. W. Michel

OTEC Heat Exchange Project

Activity

Box Y

Oak Ridge, TN 37830

Orange \& Rockland Utilities, Inc.

R. H. Metzger

Environmenta 1 Services Manager

75 West Route 59

Spring Valley, NJ 10977

Oregon State University

L. P. Davis

Department of Mechanica 1

Engineering

Corvallis, OR
No. of

Copies

Oregon State University

C. E. Wicks

Department of Chemical Engineering

Corvallis, OR 97330

Oregon State University

J. G. Knudson

Engineering Experiment Station

Corvallis, OR 97330

Pacific Gas \& Electric

A. A. Ariey

77 Beale Street

San Francisco, CA 94106

Pacific Gas \& Electric

F. F. Mautz

77 Beale Street

San Francisco, CA 94106

Pacific Power \& Light Co.

W. C. Bruaer

Public Service Bldg.

Portland, OR 97204

Pennsylvania Power \& Light

W. Duss inger

2 North Ninth Street

Allentown, PA 18101

Pennsylvania Power \& Light

D. G. Pfe iffer

2 North Ninth Street

Allentown, PA 18101

PFR Engineering Systems, Inc.

T. Rozenmann, President

Suite 832

4676 Admiralty Way

Marina del Rey, CA 90291

Philadelphia Electric Co.

J. Allen

2301 Market Street

Philadelphia, PA 19101 
Philadelphia Electric Co. S. J. Kowa lski 2301 Market Street, NZ-1

Philadelphia, PA 19101

Philadelphia Electric Co. J. B. Machel

2301 Market Street, NZ-1

Philadelphia, PA 19101

Philadelphia Electric Co.

D. Marano

2301 Market Street, NZ-1

Philadelphia, PA 19101

Prof. Ing. Car lo Roma

Piazza delle Muse 8

Rome, ITALY

Pickard Low \& Garrick

L. Rust

120018 th St. NW

Suite 612

Washington, DC 20036

Power Generation Cooling Systems

G. L. Henderson

4714-52nd Street S.

Seattle, WA 98118

Public Service of Colorado

R. F. Walker

5900 E. 39th Avenue

Denver, CO 80207

Public Service Company of Indiana

S. W. Shields

$V$. P. Engineering

100 East Main Street

Plainfield, IN 46168

Public Service Company of New Mexico

C. D. Bedford

P.0. Box 2267

Albuquerque, NM 87103
Public Service Company of New Mexico

D. J. Jroves

Supervisor, Resource Analysis

Albuquerque, NM 87103

Quirk, Lawler and Mattusky, Eng.

J. Lawler

5055 th Avenue

New York, NY 10017

Radian Corporation

F. B. Mesich

P.0. Box 9948

Austin, TX 78766

Research Cottrell

G. E. Collins

Hamon Cooling Tower Division Box 750

Bound Brook, NJ 08805

Research Cottrell

R. H. Hannon

Hamon Cooling Tower Division

Box 750

Bound Brook, NJ 08805

Resources Conservation Company

H. Herrige $]$

P.0. Box 936

Renton, WA 98055

Reynolds Aluminum Co.

R. Lindber g

Reynolds Metallurgical Research Laboratory

Richmond, VA 23261

Richmond Field Station

H. H. Sephton

47 th and Hoffman Blvd.

Richmond, CA 94804

San Diego Gas \& Electric

R. G. Lacy

101 Ash Street

San Diego, CA 92107 
No. of

Copies

Seatt le City Light

T. R. Miller

Principal Mechanical Engineer

1015 Third Avenue

Seattle, WA 98104

Seattle City Light

R. G. Sheehan

1015 Third Avenue

Seattle, WA 98104

Southern California Edison

R. S. Currie

2244 Walnut Grove Avenue

Rosemead, CA 91770

Southern California Edison

W. C. Martin

2244 Walnut Grove Avenue

Rosemead, CA 91770

Southern California Edison

F. A. McCracken

2244 Walnut Grove Avenue

Rosemead, CA 91770

Southern Services, Inc.

C. H. Goodman

P.0. Box 2625

Birmingham, AL 35202

Stanford University

A. L. London

Department of Mechanical

Engineer ing

Stanford, CA 94305

Stearns-Rogers, Inc.

J. Y. Parce

Box 5888

Denver, C0 80217

Stewart-Warner Corporation

South Wind Division

V. N. Tramontini

1514 Dover Street

Ind ianapolis, IN 46221
No. of

Copies

Stone \& Webster Engineering Corp.

D. H. Guild

225 Frank lin Street

Boston, MA 02107

Tampa Electric Co.

H. I. Wilson

P.0. Box 111

Tampa, FL 33601

Tennessee Valley Authority

Energy Research

R. D. Boroughs

1345 Commerce Union Bank Building

Chattanooga, TN 37401

Tennessee Valley Authority

H. B. Flora, III

1320 Commerce Union Bank Building

Chattanooga, TN 37401

Texas Electric Service Co.

W. Kee 1

115 W. Seventh Street

Fort Worth, TX 76102

Tucson Gas \& Electric

A. A. Ward

220 W. 6th Street

Tucson, AZ 85701

Union Carbide Corp.

J. A. Bartz

Linde Division

61 East Park Drive

Tonawanda, NY 14150

Union Carbide Corp.

J. M. Vance

ORGDP - K-25

P.O. Box P, Mail Stop 387

Oak Ridge, TN 37803

Union Carbide Corp.

$F$. Notaro

Linde Division

61 East Park Drive

Tonawanda, NY 14150 
No. of

Copies

United Engineers \& Constructors

G. A. Englesson

30 S. 17th Street

Philadelphia, PA 19103

United Engineers \& Constructors

M. Hu

30 S. 17 th Street

Philadelphia, PA 19103

University of Bremen

K. Simhan

Bremen, WEST GERMANY

University of Iowa

J. F. Kennedy

Hydraulic Research Institute

Iowa City, IA 52240

University of Kentucky

T. E. Eaton

Mechanical Engineering Department

Lexington, KY 40506

U.S. Congress

G. Ha imes

214 Massachusetts Avenue NE

Washington, DC 20510

U.S. Fish and Wildlife Service

B. L. Foder

Information Transfer Specialist

National Power Plant Team

1451 Green Road

Ann Arbor, MI 48105

United States Steel Corp.

T. L. Myron

Research Laboratory

Monroeville, PA 15146

Utah Power \& Light

M. W. Russon

1407 W. N. Temple

Salt Lake City, UT 84103
No. of

Copies

Vermont Yankee Nuclear Power

E. Gaines, Jr.

77 Grove Street

Rutland, VT 05701

Virginia Electric \& Power Co.

S. Ragone

700 E. Franklin Street

Richmond, VA 23261

Washington Public Power Supply System

J. Chasse

P.0. Box 968

300 George Washington Way

Richland, WA 99352

Washington State University

R. W. Cra in, Jr.

Department of Mechanical Engineering

Pullman, WA 99164

Washington Water Power Co.

D. L. Olson

E. 1411 Mission Avenue

Spokane, WA 99202

Water Purification Associates

H. Gold

238 Main Street

Cambridge, MA 02142

Western States Water Council

J. A. Barnett

Executive Director

220 South 2nd East

Suite 200

Salt Lake City, UT 84111

Westinghouse Electric Corp.

G. E. Jablonka

Power Generation Systems

Engineering

700 Braddock Avenue Room 9L51

East Pittsburgh, PA 15112 
No. of

Copies

Westinghouse Electric Corp.

K. Kesavan

Advanced Reactor Division

P. 0. Box 158

Madison, PA 15663

Westinghouse Electric Corp.

G. J. Silvestri

Steam Turbines Division - G108

Lester Branch

Box 9175

Philadelphia, PA 19113

Westinghouse Electric Corp.

K. A. Oleson

Steam Turbines Division - G108

Lester Branch

Box 9175

Philadelphia, PA 19113

William M. Rice University

W. G. Charack lis

Environmental Science and

Engineering

Houston, TX 77001

\section{ONSITE}

DOE Richland Operations Office

Energy Programs Division

H. E. Ransom

Westinghouse Hanford Company

Hanford Engineering Development Laboratory

\section{J. Fletcher}

85 Pacific Northwest Laboratory

E. M. Arnold (5)

R. T. Allemann

J. A. Bamberger

David J. Braun

A. J. Currie

J. W. Currie
No. of

Copies

Pacific Northwest Laboratory (contd)

D. E. Deonigi

R. L. Dillon

D. W. Dragnich

R. L. Drake

F. P. Fabro

D. W. Faletti

J. W. Finnigan

T. J. Foley

J. D. Goodenough

J. J. Hauth

A. J. Haverfield

C. H. Henager

A. B. Johnson

W. S. Kelly

R. S. Kemper

W. V. Loscutoff

R. P. Marshall

D. W. Mayer (5)

D. E. Olesen

M. S. 01sen

Y. Onishi

H. L. Parry

L. T. Pedersen

G. C. Smith

J. S. Stoakes

A. M. Sutey

R. D. Tokarz

D. S. Trent

R. A. Walter

R. L. Watts

R. D. Widrig

L. E. Wiles

C. E. Willingham

F. R. Zaloudek

File - B. M. Johnson (30)

Technical Information (5)

Publishing Coordination (RO)(2) 
i 